\title{
Opioids in the Management of Chronic Non-Cancer Pain: An Update of American Society of the Interventional Pain Physicians' (ASIPP) Guidelines
}

Andrea M. Trescot, MD, Standiford Helm, MD, Hans Hansen, MD, Ramsin Benyamin, MD, Scott E. Glaser, MD, Rajive Adlaka, MD, Samir Patel, DO, and Laxmaiah Manchikanti, MD

From: American Society of Interventional Pain Physicians.

Sukdeb Datta, MD, Nalini Sehgal,

MD, James Colson, MD, Art

Jordan, MD, and Marion Lee, MD, contributed in preparation of these

guidelines.

Additional author information is available on $\mathrm{S}_{51 .}$

Address correspondence:

ASIPP

81 Lakeview Drive

Paducah, Kentucky 42003

E-mail: asipp@asipp.org

Disclaimer: There was no external funding in the preparation of this manuscript.

Conflict of interest: Internal funding provided by the American Society of Interventional Pain Physicians was limited to travel and lodging expenses of the authors.

Free full manuscript: www.painphysicianjournal.com
Background: Opioid abuse has continued to increase at an alarming rate since our last opioid guidelines were published in 2005. Available evidence suggests a continued wide variance in the use of opioids, as documented by different medical specialties, medical boards, advocacy groups, and the Drug Enforcement Administration.

Objectives: The objectives of opioid guidelines by the American Society of Interventional Pain Physicians (ASIPP) are to provide guidance for the use of opioids for the treatment of chronic non-cancer pain, to bring consistency in opioid philosophy among the many diverse groups involved, to improve the treatment of chronic non-cancer pain, and to reduce the incidence of abuse and drug diversion.

Design: A broadly based policy committee of recognized experts in the field evaluated the available literature regarding opioid use in managing chronic non-cancer pain. This resulted in the formulation of the review and update of the guidelines published in 2006, a series of potential evidence linkages representing conclusions, followed by statements regarding the relationships between clinical interventions and outcomes.

Methods: The elements of the guideline preparation process included literature searches, literature synthesis, consensus evaluation, open forum presentations, formal endorsement by the Board of Directors of the American Society of Interventional Pain Physicians, and peer review. Based on the criteria of the U.S. Preventive Services Task Force, the quality of evidence was designated as Level I, II, and III, with 3 subcategories in Level II, with Level I described as strong and Level III as indeterminate. The recommendations were provided from $1 \mathrm{~A}$ to $2 \mathrm{C}$, varying from strong recommendation with high quality evidence to weak recommendation with low-quality or very low-quality evidence.

Results: After an extensive review and analysis of the literature, which included systematic reviews and all of the available literature, the evidence for the effectiveness of long-term opioids in reducing pain and improving functional status for 6 months or longer is variable. The evidence for transdermal fentanyl and sustained-release morphine is Level II-2, whereas for oxycodone the level of evidence is $11-3$, and the evidence for hydrocodone and methadone is Level III. There is also significant evidence of misuse and abuse of opioids.

The recommendation is $2 \mathrm{~A}$ - weak recommendation, high-quality evidence: with benefits closely balanced with risks and burdens; with evidence derived from RCTs without important limitations or overwhelming evidence from observational studies, with the implication that with a weak recommendation, best action may differ depending on circumstances or patients' or societal values.

Conclusion: Opioids are commonly prescribed for chronic non-cancer pain and may be effective for short-term pain relief. However, long-term effectiveness of 6 months or longer is variable with evidence ranging from moderate for transdermal fentanyl and sustained-re- 
lease morphine with a Level II-2, to limited for oxycodone with a Level II-3, and indeterminate for hydrocodone and methadone with a Level III.

These guidelines included the evaluation of the evidence for the use of opioids in the management of chronic non-cancer pain and the recommendations for that management. These guidelines are based on the best available evidence and do not constitute inflexible treatment recommendations. Because of the changing body of evidence, this document is not intended to be a "standard of care."

Key words: Chronic pain, persistent pain, non-cancer pain, controlled substances, substance abuse, prescription drug abuse, dependency, opioids, prescription monitoring, drug testing, adherence monitoring, diversion

Pain Physician 2008; 11:S5-S62

\subsection{INTRODUCTION}

1.1 Purpose

1.2 Rationale and Importance

1.3 Objectives and Benefits

1.4 Population and Preferences

1.5 Implementation and Review

1.6 Application

1.7 Focus

1.8 Methodology

2.0 CHRONIC PAIN

2.1 Definitions

2.2 Prevalence

2.3 Chronicity

2.4 Health and Economic Impact

2.5 Comorbidities

3.0 OPIOIDS USE IN CHRONIC PAIN

3.1 General Considerations

3.2 Response to Alleged Undertreatment

3.3 Prescription Opioids in Chronic Pain

3.4 Nonmedical Use of Prescription Drugs

3.4.1 Physician Survey Highlights

3.4.2 Pharmacist Survey Highlights

3.4.3 Drug Abuse Warning Network (DAWN) Reports

3.4.4 Healthcare and Social Costs

3.5 Substance Abuse in Chronic Pain

3.6 Economic Impact

3.7 Drug Diversion

3.8 Controlling Diversion and Abuse

3.8.1 Drug Enforcement Administration (DEA)

3.8.2 State Laws and Regulations

3.8.3 Prescription Drug Monitoring Programs (PDMP)

4.0 PHARMACOLOGICAL CONSIDERATIONS

4.1 Opioid Pharmacology

4.1.1 Opioid Receptors

4.1.2 Opioid Categories

4.1.3 Opioid Metabolism

4.2 Adverse Effects

4.3 Drug Interactions
4.4 Drug Conversions

4.5 Opioid Therapy and Side Effects

5.0 TERMINOLOGY OF ABUSE AND ADDICTION

5.1 Introduction

5.2 History

5.3 Terminology

5.3.1 Substance Abuse

5.3.2 Substance Dependence

5.3.3 Tolerance

5.3.4 Withdrawal

5.3.5 Physical Dependence

5.3.6 Addiction

5.4 Opioid Agonist Therapy

6.0 CLINICAL EFFECTIVENESS

6.1 Introduction

6.2 Systematic Reviews

6.2.1 Effectiveness of Individual Drugs

6.3 Summary of Evidence

6.4 Recommendation

\subsection{ADHERENCE MONITORING}

7.1 Introduction

7.2 Screening for Opioid Abuse

7.3 Urine Drug Testing (UDT)

7.4 Periodic Review and Monitoring

7.4.1 Periodic Review

7.4.2 Periodic Monitoring

7.4.3 Prescription Drug Monitoring

7.4.4 Periodic Education

7.4.5 Pill Counts

\subsection{PRINCIPLES OF OPIOID USAGE}

8.1 Introduction

8.2 Recommendation

8.3 Basic Philosophy

8.4 Evaluation

8.4.1 Diagnostic and Therapeutic Injections

8.4.2 Consultation

8.4.3 Informed Consent and Con-

trolled Substance Agreement

9.0 DOCUMENTATION AND MEDICAL RECORDS

10.0 KEY POINTS 


\subsection{InTRODUCTION}

\subsection{Purpose}

The American Society of Interventional Pain Physicians (ASIPP) has developed guidelines for the use of opioids in the management of non-cancer pain. They were last updated and published in Pain Physician journal in 2006 (1). These guidelines have been developed by ASIPP, so that physicians, lawmakers, and law enforcement agencies would better understand the role of opioids in non-cancer pain management algorithms. A better understanding of the risks and benefits of this class of medications should conceivably improve access to treatment for patients with chronic pain whose quality of life could be improved with opioids. In addition, a better understanding of the risks and benefits should also conceivably lead to a reduction in the abuse and diversion of this class of medications, consequences which are of grave importance. Many opioid proponent experts and some policy makers maintain that chronic pain remains undertreated with opioids and that the extent of the problem may have been underestimated. Similarly, some experts and many policy makers maintain that chronic pain may have been overtreated with opioids and the extent of the problem of abuse, diversion, and deaths may have been underestimated (2-8). Regardless of these widely diverse opinions, there is incontrovertible evidence that we are in the midst of an epidemic of prescription drug abuse and this has become a public health issue as well (2-5).

\subsection{Rationale and Importance}

The use of opioids in the management of cancer pain and palliative care has been widely accepted. The use of opioids to treat moderate to severe acute pain is also widely accepted. The use of opioids to treat chronic non-cancer pain, however, remains controversial $(6,7,9-18)$. The most significant consequences of long-term therapy include, but are not limited to, tolerance, physical and psychological dependence, abuse, and diversion (6,7-18). When utilized to treat cancer pain or in palliative care, the treatment objectives of pain control can typically be met, and the major concerns regarding the prolonged use of opioids do not have as much impact on therapeutic decision-making. This is also usually true when treating acute pain. These issues, however, are of grave consequence when considering the prescription of opioids for chronic benign pain with evidence of lack of effectiveness and significant complications (6-19).
Another significant factor that accounts for the discrepancy in the acceptance of the use of opioids for chronic benign pain is the actual goals of treatment in this patient population. The treatment objectives in chronic benign pain are subtly, but significantly, different and more complex than the goals of opioid therapy in the settings of terminal conditions or acute pain. The objective of the treatment of chronic pain of a non-cancer origin include, when possible, not only management of painful symptoms but an emphasis on maintaining functionality and continued participation in society. These objectives can be thwarted by the use of opioids depending on multiple factors. These factors include, but are not limited to, the psychological make up of the patient, the type of pain being treated, and the skills, knowledge, and resources of the clinician.

\subsection{Objectives and Benefits}

The objective of these guidelines is to provide clear and concise guidelines to physicians, to improve patient access, and avoid diversion and abuse. The perceived benefits of these guidelines include:

- Increased physician awareness about the current issues involving opioids and non-cancer pain

- Improved patient access

- Reduced level of opioid abuse

- Improved ability to manage patient expectations

- Reduced diversion

- Improved understanding by law enforcement about proper prescribing patterns

- Improved cooperation among patients, providers, and regulatory agencies

- Improved understanding by patients regarding their rights as well as their responsibilities when taking opioid medications

\subsection{Population and Preferences}

The population covered by these guidelines includes all patients with chronic moderate to severe pain of non-cancer origin who may be eligible for appropriate medically necessary opioid analgesic management. This management may include or be independent of interventional techniques.

\subsection{Implementation and Review}

The dates for implementation and review were established:

- Effective date - February 1, 2008

- Scheduled review - July 1, 2011

- Expiration date - January 31, 2012 


\subsection{Application}

These guidelines were developed to be used by physicians practicing interventional pain management and do not constitute inflexible treatment recommendations. These guidelines are not intended to address all possible clinical situations where opioids might be used for non-cancer pain in clinical practice. It is expected that a provider will establish a plan of care on a case-by-case basis, taking into account an individual patient's medical condition, personal needs, and preferences, as well as the physician's experience. Based on an individual patient's needs, treatment different from that outlined here could be warranted. These guidelines do not represent "standard of care."

\subsection{Focus}

The focus of these guidelines is the effective management of chronic non-cancer pain, as well as the various issues involved in opioid administration. It is recognized that management of chronic non-cancer pain takes place in a wide context of healthcare, involving multiple specialists and multiple techniques. Guidelines cannot be applied to all patients. Consequently, the decision to implement a particular management approach should be based on a comprehensive assessment of the patient's overall health status, disease state, patient preference, and physician training and skill.

\subsection{Methodology}

A policy committee was convened and included a broad representation of academic and clinical practitioners, representing a variety of practices and geographic areas, all recognized as experts in opioid use and management of patients with chronic non-cancer pain. This committee formalized the essentials of the guidelines. The elements of the guidelines preparation process included literature searches, literature synthesis, consensus evaluations, open forum presentations, formal endorsement by the ASIPP board of directors and peer review (20-40).

Evidence-based medicine is defined as the conscientious, explicit, and judicious use of current best evidence in making decisions about the care of individual patients (41). It is not "cookbook" medicine, but instead requires an integration of the best external evidence combined with individual clinical expertise and the patient's choice. While an evidence-based approach may seem to enhance the scientific rigor of guideline development, recommendations may not always meet the highest scientific standards (42). The study of pain treatments has been limited due to the subjective nature of pain, especially non-cancer pain, and the effectiveness of interventions (such as the use of opioids) has to be judged relative to non-intervention $(39,43-50)$.

In preparation of these guidelines, it is recognized that at the core of an evidence-based approach to clinical or public health issues is, inevitably, the evidence itself, which needs to be carefully gathered and collated from a systematic literature review of the particular issues. It follow that process by which the strength of scientific evidence is evaluated in the development of evidence-based medicine recommendations and guidelines is crucial. The practice of evidence-based medicine requires the integration of individual clinical expertise with the best available clinical evidence from systematic research.

Systems for grading the strength of a body of evidence are much less uniform and consistent than those for rating study quality (24-40). Consequently, the guideline committee designed levels of evidence from Level I through Level III, adapted from the U.S. Preventive Services Task Force (USPSTF) (26) as shown in Table 1.

Table 1. Quality of evidence.

\begin{tabular}{|c|c||}
\hline I: & Evidence obtained from at least one properly randomized controlled trial. \\
\hline II-1: & Evidence obtained from well-designed controlled trials without randomization. \\
\hline II-2: & $\begin{array}{r}\text { Evidence obtained from well-designed cohort or case-control analytic studies, preferably from more than one center or research group. } \\
\text { the results of the introduction of penicillin treatment in the 1940s) could also be regarded as this type of evidence. }\end{array}$ \\
\hline III: & $\begin{array}{r}\text { Evidence obtained from multiple time series with or without the intervention. Dramatic results in uncontrolled experiments (such as } \\
\text { Opinions of respected authorities, based on clinical experience descriptive studies and case reports or reports of expert committees. }\end{array}$ \\
\hline \hline
\end{tabular}

Adapted from the Agency for Healthcare Research and Quality U.S. Preventive Services Task Force (USPSTF) (Ref. 24) 
Recommendations were provided based on methodological quality of supporting evidence, benefit versus risks and burdens, and implications (37) (Table 2).

\subsection{Chronic Pain}

\subsection{Definitions}

Acute pain is a vital, protective mechanism that allows us to live in an environment filled with potential dangers. On the other hand, chronic pain serves no such physiologic function, and is itself not a useful symptom. Chronic pain is difficult to define. Consequently, a combination of multiple definitions must be utilized.
- Pain that persists beyond the usual course of an acute disease or a reasonable time for any injury to heal that is associated with chronic pathologic processes that cause continuous pain or pain at intervals for months or years

- Persistent pain that is not amenable to routine pain control methods.

\subsection{Prevalence}

Any description of the epidemiology of chronic pain starts with its significance as a national public health problem. In a survey of chronic pain in America conducted by the American Pain Society (an advocacy group), $9 \%$ of the adult population was shown

Table 2. Grading recommendations.

\begin{tabular}{|c|c|c|c|}
\hline $\begin{array}{l}\text { Grade of Recommendation/ } \\
\text { Description }\end{array}$ & $\begin{array}{l}\text { Benefit vs Risk and } \\
\text { Burdens }\end{array}$ & $\begin{array}{l}\text { Methodological Quality of } \\
\text { Supporting Evidence }\end{array}$ & Implications \\
\hline $\begin{array}{l}1 \mathrm{~A} / \text { strong recommendation, } \\
\text { high-quality evidence }\end{array}$ & $\begin{array}{l}\text { Benefits clearly outweigh } \\
\text { risk and burdens, or vice } \\
\text { versa }\end{array}$ & $\begin{array}{l}\text { RCTs without important limitations } \\
\text { or overwhelming evidence from } \\
\text { observational studies }\end{array}$ & $\begin{array}{l}\text { Strong recommendation, } \\
\text { can apply to most patients in } \\
\text { most circumstances without } \\
\text { reservation }\end{array}$ \\
\hline $\begin{array}{l}1 \mathrm{~B} / \text { strong recommendation, } \\
\text { moderate quality evidence }\end{array}$ & $\begin{array}{l}\text { Benefits clearly outweigh } \\
\text { risk and burdens, or vice } \\
\text { versa }\end{array}$ & $\begin{array}{l}\text { RCTs with important limitations } \\
\text { (inconsistent results, methodological } \\
\text { flaws, indirect, or imprecise) or } \\
\text { exceptionally strong evidence from } \\
\text { observational studies }\end{array}$ & $\begin{array}{l}\text { Strong recommendation, } \\
\text { can apply to most patients in } \\
\text { most circumstances without } \\
\text { reservation }\end{array}$ \\
\hline $\begin{array}{l}\text { 1C/strong recommendation, } \\
\text { low-quality or very low-quality } \\
\text { evidence }\end{array}$ & $\begin{array}{l}\text { Benefits clearly outweigh } \\
\text { risk and burdens, or vice } \\
\text { versa }\end{array}$ & Observational studies or case series & $\begin{array}{l}\text { Strong recommendation but } \\
\text { may change when higher quality } \\
\text { evidence becomes available }\end{array}$ \\
\hline $\begin{array}{l}\text { 2A/weak recommendation, high- } \\
\text { quality evidence }\end{array}$ & $\begin{array}{l}\text { Benefits closely balanced } \\
\text { with risks and burden }\end{array}$ & $\begin{array}{l}\text { RCTs without important limitations } \\
\text { or overwhelming evidence from } \\
\text { observational studies }\end{array}$ & $\begin{array}{l}\text { Weak recommendation, best } \\
\text { action may differ depending on } \\
\text { circumstances or patients' or } \\
\text { societal values }\end{array}$ \\
\hline $\begin{array}{l}2 \mathrm{~B} / \text { weak recommendation, } \\
\text { moderate-quality evidence }\end{array}$ & $\begin{array}{l}\text { Benefits closely balanced } \\
\text { with risks and burden }\end{array}$ & $\begin{array}{l}\text { RCTs with important limitations } \\
\text { (inconsistent results, methodological } \\
\text { flaws, indirect, or imprecise) or } \\
\text { exceptionally strong evidence from } \\
\text { observational studies }\end{array}$ & $\begin{array}{l}\text { Weak recommendation, best } \\
\text { action may differ depending on } \\
\text { circumstances or patients' or } \\
\text { societal values }\end{array}$ \\
\hline $\begin{array}{l}2 \mathrm{C} / \text { weak recommendation, } \\
\text { low-quality or very low-quality } \\
\text { evidence }\end{array}$ & $\begin{array}{l}\text { Uncertainty in the estimates } \\
\text { of benefits, risks, and } \\
\text { burden; benefits, risk, and } \\
\text { burden may be closely } \\
\text { balanced }\end{array}$ & Observational studies or case series & $\begin{array}{l}\text { Very weak recommendations; } \\
\text { other alternatives may be equally } \\
\text { reasonable }\end{array}$ \\
\hline
\end{tabular}

Adapted from Guyatt et al (37). Grading strength of recommendations and quality of evidence in clinical guidelines. Report from an American College of Chest Physicians task force. Chest 2006; 129:174-181. 
to suffer from moderate to severe, non-cancer-related pain (51). Further, two-thirds of these people have been living with the pain for over 5 years and the pain was found to have a significant impact on the quality of life and emotional well-being, with patients experiencing significant improvements in these factors when their pain was well controlled. Other studies have shown the prevalence of chronic pain in the adult population ranging from $2 \%$ to $40 \%$, with a median point prevalence of $15 \%(52,53)$. Persistent pain was reported with an overall prevalence of $20 \%$ of primary care patients, with approximately $48 \%$ reporting back pain (54). A systematic review of 4 international studies conducted in developed countries found prevalence rates of any type and severity level of chronic pain ranging from $10.5 \%$ to $55.2 \%$ of the population (55). A European survey of 46,000 individuals showed that 1 in 5 people reported suffering from chronic pain (56). This survey also showed that chronic pain sufferers reported 7 years of chronic pain on average, with some reporting pain lasting more than 20 years. A survey of Americans (57) showed $9 \%$ of Americans suffer with moderate-to-severe chronic non-cancer pain. An Australian study of over 17,000 people (53) showed the prevalence of chronic pain in $17.1 \%$ of males and $20 \%$ of females with the prevalence for males peaking at $27 \%$ in the 65-69 year age group and for females, prevalence peeking at $31 \%$ in the oldest age group of 80-84 years. Further, chronic pain is not only seen in adults, but it is also seen in the elderly and children (58-63). Various non-cancer pain problems include spinal pain, osteoarthritis, ischemic pain syndromes, visceral pain syndromes, neuropathic pain syndromes, and headache.

Recent publications have confirmed the above reported findings. Estimates of the prevalence of arthritis and other rheumatic conditions in the United States $(64,65)$, showed more than $21 \%$ of U.S. adults, or 46.4 million persons, were found to have selfreported, physician-diagnosed arthritis. This study estimated that rheumatoid arthritis affects 1.3 million adults (down from the estimate of 2.1 million for 1995), juvenile arthritis affects 294,000 children, spondylarthritides affects from 0.6 million to 2.4 million adults, systemic lupus erythematosus affects 161,000 to 332,000 adults, systemic sclerosis affects 49,000 adults, and primary Sjögren's syndrome affects from 0.4 million to 3.1 million adults (64). Part II of this study (65) also estimated that among U.S. adults, nearly 27 million have clinical arthritis (up from the estimate of 21 million for 1995), 711,000 have polymyalgia rheumatica, 228,000 have giant cell arteritis, up to 3.0 million have had self-reported gout in the past year (up from the estimate of 2.1 million for 1995), 5.0 million have fibromyalgia, 4 to 10 million have carpal tunnel syndrome, 49 million have had low back pain in the past 3 months, and 30.1 million have had neck pain in the past 3 months. These reports are considered to be the best available prevalence estimates for the United States, but for most specific conditions, more studies generalizable to the United States for addressing understudied populations are needed.

Neuropathic pain is apparently common, with an estimated prevalence in the general population of 7 to $8 \%$ (66-68). However, because neuropathic pain consists of a number of different disease-specific indications, each of which can have differing diagnostic definitions and cutoffs, it is difficult to estimate precisely its prevalence and incidence (69). Neuropathic pain also affects between $8 \%$ and $50 \%$ of all diabetics (70). Diabetic peripheral neuropathy shares certain similarities (both in clinical presentation and response to treatment) with other forms of neuropathic pain. The prevalence of neuropathic pain after thoracic surgery is high, with $57 \%$ complaining of neuropathic pain at $7-12$ months, $36 \%$ at $4-5$ years, and $21 \%$ at 6-7 years (71). Breast cancer patients may complain of "phantom" breast pain for months to years after surgery (72).

\subsection{Chronicity}

Duration of pain and its chronicity have been topics of controversy. Conventional beliefs are that most episodes of low back pain will be short-lived, with $80 \%$ to $90 \%$ of attacks resolving in about 6 weeks irrespective of the administration or type of treatment, and only $5 \%$ to $10 \%$ of patients developing persistent back pain (73-82). However, this commonly held belief has been questioned, as in reality, the condition tends to relapse, so that most patients will experience recurrent episodes. Almost $60 \%$ of spinal pain patients have suffered from chronic pain from 2 to 15 years $(53,56,73-$ 82). Further, overwhelming evidence shows that chronic persistent low back pain and neck pain in children and adults are seen in up to $60 \%$ of the patients, 5 years or longer after the initial episode $(73,76-83)$.

\subsection{Health and Economic Impact}

Chronic non-cancer pain is associated with sig- 
nificant economic, societal, and health impact (84-93). The cost of uncontrolled chronic pain is enormous, both to individuals and to society as it leads to a decline in the quality of life and disability. Estimates and patterns of direct healthcare expenditures among individuals with back pain in the United States reached $\$ 90.7$ billion for the year 1998 (84). On average, individuals with back pain generate healthcare expenditures about $60 \%$ higher than do individuals without back pain $(\$ 3,498$ per year versus $\$ 2,178)$. It has been estimated that the cost of healthcare for patients with chronic pain might exceed the combined cost of treating patients with coronary artery disease, cancer, and AIDS (94). In the United States, it was estimated that the cost of treatment in the first year after failed back surgery for pain was approximately \$18,883 in 1997 (95). Even further, annual healthcare cost incurred by chronic pain patients, excluding cost for surgical procedures, may range from $\$ 500$ to as high as $\$ 35,400$, with averages ranging from $\$ 12,900$ to $\$ 18,883$ annually $(96,97)$.

The economic costs for chronic pain in general have been estimated to be over $\$ 86$ billion per year (97). A cross-sectional study, based on survey data from 28,902 working adults in the USA was reported in 2003 with $13 \%$ of the workforce experiencing a loss of productivity during a 2 week period due to a common pain condition (98). In monetary terms, this loss of productivity was calculated to cost $\$ 61.3$ billion, with $\$ 14.4$ billion due to absenteeism and the rest due to the survey participants being at work, but with impaired productivity due to the pain.

In a recent survey of expenditures and health status among adults with back and neck problems (92), self-reported back and neck problems accounted for a large proportion of health care expenditures and spine-related expenditures have increased substantially from 1997 to 2005, without evidence of corresponding improvement in self-assessed health status. In this national estimate based on annual samples of survey respondents with and without self-reported spine problems from 1997 through 2005, a total of 23,045 respondents were sampled in 1997, including 3,139 who reported spine problems. In 2005, the sample included 22,258 respondents, including 3,187 who reported spine problems. This survey showed that in 1997, the adjusted medical cost for respondents with spine problems was $\$ 4,695(95 \%$ $\mathrm{Cl}, \$ 4,181$ to $\$ 5,209)$, compared with $\$ 2,731(95 \% \mathrm{Cl}$, $\$ 2,557$ to $\$ 2,904)$ among those without spine prob- lems in terms in inflation-adjusted dollars. Conversely, in 2005, the adjusted medical expenditures among respondents with spine problems was \$6,096 (95\% $\mathrm{Cl}, \$ 5670$ to $\$ 6,522)$, compared with $\$ 3,516(95 \% \mathrm{Cl}$, $\$ 3,266$ to $\$ 3,765)$ among those without spine problems. Consequently, total estimated expenditures among respondents with spine problems increased $65 \%$ after adjusting for inflation from 1997 to 2005, more rapidly than overall health expenditures. This is in contrast to the estimated proportion of persons with back or neck problems with self-reported physical function and limitations increasing from $20.7 \%$ $(95 \% \mathrm{Cl}, 19.9 \%$ to $21.4 \%)$ to $24.7 \%(95 \% \mathrm{Cl}, 23.7 \%$ to $25.6 \%$ ) from 1997 to 2005 , which is an increase of $4 \%$.

In one study evaluating the burden and determinants of neck pain in the general population (91) and in workers (93) after evaluating numerous studies (101 for general population and 109 for workers), the 12month prevalence of pain typically ranged between 30 and $50 \%$, while, the 12 -month prevalence of activity-limiting pain was $1.7 \%$ to $11.5 \%$ in the general population, in workers, the annual prevalence of neck pain varied from $27.1 \%$ to $47.8 \%$, with between $11 \%$ and $14.1 \%$ of workers limiting their activities due to neck pain.

\subsection{Comorbidities}

Chronic pain sufferers are considered to be heavy users of healthcare services, often presenting with multiple or unexplained symptoms. Studies indicate that only $2 \%$ to $5 \%$ of chronic pain sufferers have been evaluated or treated by a pain specialist $(56,99)$, whereas many patients seek alternative practitioners (100), and a high proportion take prescription or overthe-counter medications.

Chronic pain also has high functional impairment impact on the sufferer's day-to-day function, with a range of activities being curtailed. Patients with chronic pain report difficulties with daily chores, social life, and work, and a higher rate of unemployment (101-104). It has been shown that $19 \%$ of patients had lost their job because of chronic pain (56). In addition, chronic pain sufferers have been shown to have low scores for quality of life $(105,106)$.

Increased comorbidity, disability, and costs have been described widely in the chronic pain population (107-126). In a study of 1,484 community dwelling Australian women 70 to 85 years of age, daily back pain was shown to be associated with reduced quality 
of life, mobility and longevity, and increased risk of coronary heart events (107). In a descriptive report of the longitudinal course of depressive symptoms and pain experienced by continuing care retirement community residents, in 169 residents, 37\% met the criteria for chronic activity-limiting pain, 21\% met the criteria for chronic high depressive symptoms, and $13 \%$ were comorbid (63). In another study of an elderly population, both pain and depression affected physical performance, with depression having more an influential effect on the decline of physical performance and causing increased levels of functional impairment. This was also confirmed in a prospective study of patients with disabling low back pain and depressive symptoms in a community-dwelling population of over 90,000 elderly, more than 50,000 of whom were being surveyed for the follow-up purposes after 2 years (109). This study showed that among community-dwelling elderly persons, depressive symptoms and disabling low back pain were widespread, with depressive symptoms predicting disabling low back pain and vice versa. Multiple studies have addressed the impact of chronic spinal pain (112-114), headache $(115,117,118)$, and various types of pain.

Extensive research of involvement of psychological disorders in the chronic pain population has been published (120-134). Since pain is defined as both a physiological sensation and a psychological condition or state (126), the neural event of pain is in many ways inextricable from the psychological or phenomenological experience of pain (127). Consequently, chronic pain in particular manifests a psychological constellation of cognitive, emotional, and behavioral characteristics. Numerous studies have shown that a significant proportion of pain patients present with depression, anxiety, and somatization disorder, either alone or in combination (120$125,128-133)$. In studies that have evaluated chronic pain patients, the comorbidity of major depression ranged from $15 \%$ to $56 \%$, significantly higher than the occurrence of major depression within the general population, which ranged from $5 \%$ to $10 \%$. Similarly, the occurrence of somatization disorder ranged from $20 \%$ to $31 \%$ in chronic pain patients, compared to $1 \%$ to $4 \%$ in the general population. Consequently, the prevalence of pain is noted to increase with the association of comorbidities, and the prevalence of pain continues to increase, along with psychological and substance abuse disorders.

\subsection{Opioids Use in Chronic Pain}

\subsection{General Considerations}

Inadequate treatment of pain has been attributed to a lack of knowledge about pain management options, inadequate understanding of addiction, or fears of investigation or sanction by federal, state, and local regulatory agencies (1-6,134-136). Proponents of opioid drug therapy for all types of pain contend that opioid analgesic therapy plays an important role in pain management and should be available when needed for the treatment of all kinds of pain, including noncancer pain, without restriction of dosage or frequency (135). Further, the Drug Enforcement Adminstration (DEA) has also taken the position that clinicians should be knowledgeable about using opioids to treat pain, and should not hesitate to prescribe them when opioids are the best clinical choice of treatment (137). In addition to the DEA, model guidelines adapted by the Federation of State Medical Boards also encourage opioid management with proper documentation (138).

\subsection{Response to Alleged Undertreatment}

The alleged undertreatment of pain as a major health problem in the United States led to the development of initiatives to address the multiple alleged barriers responsible for the undertreatment of pain. Consequently, numerous clinical guidelines have been developed, even though none of them were based on evidence-based medicine. In 2001, the Joint Commission on the Accreditation of Healthcare Organizations (JCAHO) introduced the concept that pain was the "fifth vital sign," in an effort to increase the awareness of pain in the hospitalized patient, and by design, improve the treatment of that pain. Unfortunately, the current emphasis on pain assessment as the fifth vital sign has resulted in the potential overmedication of a group of patients (139). The results of the effect of JCAHO regulations have been controversial (140-142). One study showed that opioid adverse drug reactions increased significantly from 11 to 24.5 per 100,000 inpatient hospital days (140). However another study (141) showed increased opioid consumption without an increase in the length of the stay, increase in the use of naloxone, or an increase in treatment for postoperative nausea and vomiting. Yet, another study (142) showed that routinely measuring pain by the fifth vital sign did not increase the quality of pain management. 
Multiple reviews $(6,9-19)$ have shown a lack of consistent effectiveness of opioids in reducing pain and improving functional status. A cost analysis of chronic spinal pain (143) suggested that treatment with medications alone did not significantly improve a patients' ability to stand, sit, walk, travel, socialize, and work both in and outside the home. However, complementary treatment components, such as anesthetic procedures, physical therapy, group education, and cognitive-behavioral psychotherapy, seemed to directly affect patients' pain-related functional impairments. It is argued that physicians should be encouraged to prescribe opioids because they are indispensable for the treatment of pain and suffering, because uncontrolled pain may have deleterious physical effects, and because persistent pain destroys peoples' autonomy, dignity, and decision-making capacity $(6,14,144,145)$. Thus, the availability of opioids has skyrocketed dramatically in the past few decades, partly due to politics and the emotional issues involved with efforts to improve awareness and treatment of chronic pain. Despite equal recognition of the major side effects - drug abuse and addiction - by opponents and equally by proponents, proponents continue to promote extensive opioid use under the umbrella of undertreatment of pain, leading to an explosion in opioid therapy. As a result, most patients (over $90 \%$ ) presenting to pain management settings, and receiving treatment at pain management centers have been receiving opioids, in spite of problems of abuse, diversion, and other side effects $(120,146-170)$. The therapeutic use of opioids has exploded in the United States, witnessed by increased sales of hydrocodone by $244 \%$ from 1997 to 2006 , while methadone usage increased $1,177 \%$ and oxycodone increased $732 \%$ (Table 3 and Fig. 1) (5). Coupled with increased retail sales in therapeutic opioid usage, the pattern of type of opioid usage also has changed. In 1997, the most commonly used opioid was codeine, followed by hydrocodone and oxycodone. However, in 2006, the most commonly used opioid was oxycodone, followed by hydrocodone and morphine.

Overall, opioids increased from 50.7 million grams of medication in 1997 to 115.3 million grams of medication in 2006, an overall increase of $127 \%$ (5). In addition, the estimated number of prescriptions filled for controlled substances increased from 222 million in 1994 to 354 million in $2003(4,171,172)$. Prescriptions

Table 3. Retail sales of opioid medications (grams of medication), 1997-2006.

\begin{tabular}{|c|c|c|c|c|c|c|c|c|c|c|c|}
\hline Drug & 1997 & 1998 & 1999 & 2000 & 2001 & 2002 & 2003 & 2004 & 2005 & 2006 & $\begin{array}{c}\% \text { of } \\
\text { change } \\
\text { from } \\
1997\end{array}$ \\
\hline Methadone & 518,737 & $\begin{array}{c}692,675 \\
(34 \%)\end{array}$ & $\begin{array}{c}964,982 \\
(39 \%)\end{array}$ & $\begin{array}{c}1,428,840^{*} \\
(48 \%)\end{array}$ & $\begin{array}{c}1,892,691 \\
(32 \%)\end{array}$ & $\begin{array}{c}2,649,559 \\
(40 \%)\end{array}$ & $\begin{array}{c}3,683,881 \\
(39 \%)\end{array}$ & $\begin{array}{c}4,730,157 \\
(28 \%)\end{array}$ & $\begin{array}{c}5,362,815 \\
(13 \%)\end{array}$ & $\begin{array}{c}6,621,687 \\
(23 \%)\end{array}$ & $1177 \%$ \\
\hline Oxycodone & $4,449,562$ & $\begin{array}{c}6,579,719 \\
(48 \%)\end{array}$ & $\begin{array}{c}9,717,600 \\
(48 \%)\end{array}$ & $\begin{array}{c}15,305,913 \\
(58 \%)\end{array}$ & $\begin{array}{c}19,927,286 \\
(30 \%)\end{array}$ & $\begin{array}{c}22,376,892 \\
(12 \%)\end{array}$ & $\begin{array}{c}26,655,152 \\
(19 \%)\end{array}$ & $\begin{array}{c}29,177,530 \\
(9 \%)\end{array}$ & $\begin{array}{c}30,628,973 \\
(5 \%)\end{array}$ & $\begin{array}{c}37,034,220 \\
(21 \%)\end{array}$ & $732 \%$ \\
\hline Fentanyl Base & 74,086 & $\begin{array}{l}90,618 \\
(22 \%) \\
\end{array}$ & $\begin{array}{c}107,141 \\
(18 \%)\end{array}$ & $\begin{array}{c}146,612^{*} \\
(37 \%)\end{array}$ & $\begin{array}{c}186,083 \\
(27 \%)\end{array}$ & $\begin{array}{c}242,027 \\
(30 \%)\end{array}$ & $\begin{array}{c}317,200 \\
(31 \%)\end{array}$ & $\begin{array}{c}370,739 \\
(17 \%)\end{array}$ & $\begin{array}{c}387,928 \\
(5 \%)\end{array}$ & $\begin{array}{c}428,668 \\
(11 \%)\end{array}$ & $479 \%$ \\
\hline Hydromorphone & 241,078 & $\begin{array}{c}260,009 \\
(8 \%)\end{array}$ & $\begin{array}{c}292,506 \\
(12 \%)\end{array}$ & $\begin{array}{c}346,574^{*} \\
(18 \%)\end{array}$ & $\begin{array}{c}400,642 \\
(16 \%)\end{array}$ & $\begin{array}{c}473,362 \\
(18 \%)\end{array}$ & $\begin{array}{c}579,372 \\
(22 \%)\end{array}$ & $\begin{array}{c}655,395 \\
(13 \%)\end{array}$ & $\begin{array}{c}781,287 \\
(19 \%)\end{array}$ & $\begin{array}{c}901,663 \\
(15 \%\end{array}$ & $274 \%$ \\
\hline Hydrocodone & $8,669,311$ & $\begin{array}{c}10,389,503 \\
(20 \%) \\
\end{array}$ & $\begin{array}{c}12,101,621 \\
(16 \%)\end{array}$ & $\begin{array}{c}14,118,637 \\
(17 \%)\end{array}$ & $\begin{array}{c}15,594,692 \\
(10 \%) \\
\end{array}$ & $\begin{array}{c}18,822,619 \\
(21 \%)\end{array}$ & $\begin{array}{c}22,342,174 \\
(19 \%) \\
\end{array}$ & $\begin{array}{c}24,081,900 \\
(8 \%)\end{array}$ & $\begin{array}{c}25,803,543 \\
(7 \%) \\
\end{array}$ & $\begin{array}{c}29,856,368 \\
(16 \%)\end{array}$ & $244 \%$ \\
\hline Morphine & $5,922,872$ & $\begin{array}{c}6,408,322 \\
(8 \%)\end{array}$ & $\begin{array}{c}6,804,935 \\
(6 \%)\end{array}$ & $\begin{array}{c}7,807,511 \\
(15 \%)\end{array}$ & $\begin{array}{c}8,810,700 \\
(13 \%)\end{array}$ & $\begin{array}{c}10,264,264 \\
(16 \%)\end{array}$ & $\begin{array}{c}12,303,956 \\
(20 \%)\end{array}$ & $\begin{array}{c}14,319,243 \\
(16 \%)\end{array}$ & $\begin{array}{c}15,054,846 \\
(5 \%)\end{array}$ & $\begin{array}{c}17,507,148 \\
(16 \%)\end{array}$ & $196 \%$ \\
\hline Codeine & $25,071,410$ & $\begin{array}{c}26,018,054 \\
(4 \%)\end{array}$ & $\begin{array}{c}23,917,088 \\
(-8 \%)\end{array}$ & $\begin{array}{c}23,474,865^{*} \\
(-2 \%)\end{array}$ & $\begin{array}{c}23,032,641 \\
(-2 \%)\end{array}$ & $\begin{array}{c}22,633,733 \\
(-2 \%)\end{array}$ & $\begin{array}{c}21,865,409 \\
(-3 \%)\end{array}$ & $\begin{array}{c}20,264,555 \\
(-7 \%)\end{array}$ & $\begin{array}{c}18,960,038 \\
(-6 \%)\end{array}$ & $\begin{array}{c}18,762,919 \\
(-1 \%\end{array}$ & $-25 \%$ \\
\hline $\begin{array}{l}\text { Meperidine } \\
\text { (Pethidine) }\end{array}$ & $5,765,954$ & $\begin{array}{c}5,834,294 \\
(1 \%)\end{array}$ & $\begin{array}{c}5,539,592 \\
(-5 \%)\end{array}$ & $\begin{array}{c}5,494,898^{*} \\
(-1 \%)\end{array}$ & $\begin{array}{c}5,450,204 \\
(-1 \%)\end{array}$ & $\begin{array}{c}5,412,389 \\
(-1 \%)\end{array}$ & $\begin{array}{c}5,239,932 \\
(-3 \%)\end{array}$ & $\begin{array}{c}4,856,644 \\
(-7 \%)\end{array}$ & $\begin{array}{c}4,272,520 \\
(-12 \%)\end{array}$ & $\begin{array}{c}4,160,033 \\
(-3 \%)\end{array}$ & $-28 \%$ \\
\hline Total & $50,713,010$ & $\begin{array}{c}56,273,194 \\
(11 \%)\end{array}$ & $\begin{array}{c}59,445,465 \\
(6 \%)\end{array}$ & $\begin{array}{c}35,962,089.84 \\
(15 \%)\end{array}$ & $\begin{array}{c}75,294,939 \\
(11 \%)\end{array}$ & $\begin{array}{c}82,874,845 \\
(10 \%)\end{array}$ & $\begin{array}{c}92,987,076 \\
(12 \%)\end{array}$ & $\begin{array}{c}98,456,163 \\
(6 \%)\end{array}$ & $\begin{array}{c}101,251,950 \\
(6 \%)\end{array}$ & $\begin{array}{c}115,272,706 \\
(14 \%)\end{array}$ & $127 \%$ \\
\hline
\end{tabular}

Numbers in parenthesis are percentage of change from previous year. ${ }^{*}$ For year 2000, data is not available; the average of 1999 and 2001 was taken. Source: www.deadiversion.usdoj.gov/arcos/retail_drug_summary/index.html

Adapted from Manchikanti and Singh (5). Therapeutic opioids: A ten-year perspective on the complexities and complications of the escalating use, abuse, and nonmedical use of opioids. Pain Physician 2008; 11: S63-S88. 


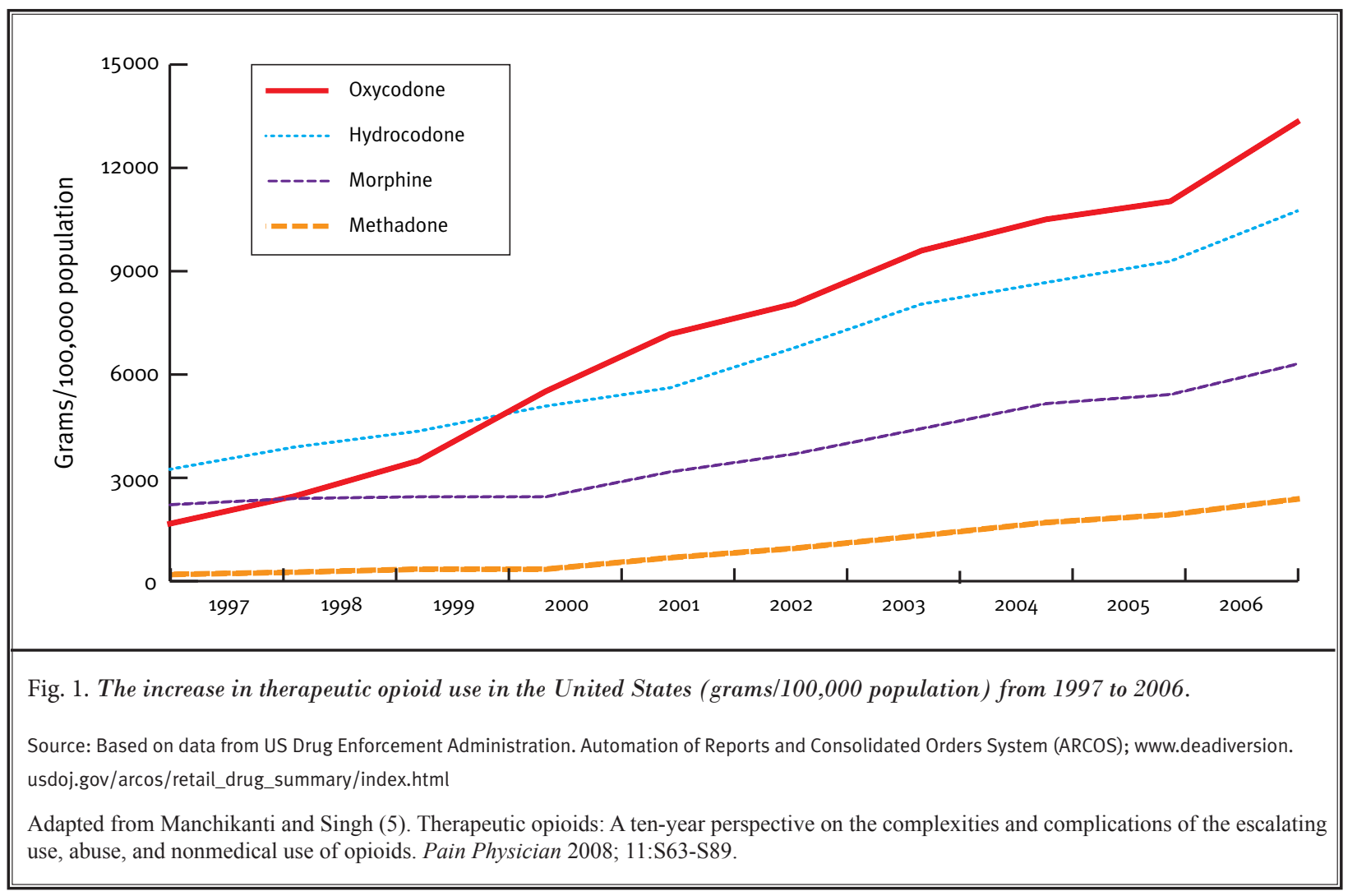

for controlled substances increased by $154 \%$, compared to the number of prescriptions written for noncontrolled drugs which increased by $57 \%$ (173-175). As a result, the milligram per person use of therapeutic opioids in the United States increased from approximately $74 \mathrm{mg}$ in 1997 to $329 \mathrm{mg}$ per person in 2006, an increase of $347 \%$ (Table 4) (5). Fig. 2 illustrates total prescriptions for selected narcotic analgesics for 2006 $(5,176,177)$. In 2006 , there were about 35 -fold more hydrocodone prescriptions, 10-fold more oxycodone prescriptions, and 2-fold more fentanyl prescriptions compared to methadone prescriptions. In addition, Americans, constituting only $4.6 \%$ of the world's population, have been consuming $80 \%$ of the global opioid supply, and $99 \%$ of the global hydrocodone supply, along with two-thirds of the world's illegal drugs (1-5, 178-181).

Multiple authors also have evaluated the increase in opioid use along with cost and health consequences which have been increasing substantially over the years (182-184). The analysis of the National Ambulatory Medical Care Survey, using data from 1980 to 1981 and 1999 to 2000, evaluating over 130,000 visits showed the doubling of opioid use for chronic pain from $8 \%$ to $16 \%$ and for acute pain the increase was from $8 \%$ to $11 \%$ (182). In addition, the study also showed that prescriptions for more potent opioids such as hydrocodone, oxycodone, and morphine increased from $2 \%$ to $9 \%$ in visits corresponding to 5.9 million visits in 2002 - an increase of 4.6 million visits from 1980 for chronic musculoskeletal pain. Further, in the analysis of analgesic use for low back pain and its impact on health care costs and service use (183), in $2001,55.5 \%$ of members with claims for low back services received analgesics costing a total of $\$ 1.4$ million, of which $68 \%$ were opioids. Opioid use was also associated with high volume usage of low back pain services and correlated with the higher use of opioids in patients with psychogenic pain and low back pain related to orthopedic devices such as fusion. There have been reports of association of opioid use with increased disability, medical costs, subsequent surgery, and continued or late opioid use (182-186). Webster et al (185) showed that patients receiving more than $450 \mathrm{mg}$ equivalent of morphine over a period of several months were, on average, disabled 69 days lon- 
ger than those who received no early opioids, and also had 3 times the increased risk for surgery, along with 6 times the increased risk of receiving late opioids. Greater self-reported disability and poor function was associated with opioid use (187). Finally, an epidemiological study from Denmark (188) demonstrated worse pain, higher health care utilization, and lower activity levels in opioid treated patients compared to a matched cohort of chronic pain patients not using opioids, suggesting that when opioids are prescribed liberally, even if some patients benefit, the overall population does not. Opioids are prescribed liberally for chronic pain in Denmark. In an evaluation of primary care patients, the frequency of opioid disorders was 4 times higher in patients receiving opioid therapy compared with general population samples $(3.8 \%$ vs $0.9 \%)(189)$.

\subsection{Prescription Opioids in Chronic Pain}

Numerous reviews have critically evaluated the effectiveness of opioid therapy in chronic pain $(1,6,11-19)$. In a meta-analysis of opioid use in patients with chronic low back pain, Martell et al (10) concluded that opioids do not provide effective pain relief and do not increase functional status in chronic low back pain. Ballantyne (6), after directly comparing the efficacy of different opioids, concluded that a non-significant reduction in pain was present. Chou et al (11) concluded there was insufficient and poor evidence to prove the safety or effectiveness or any opioids. Kalso et al (12) in their critical anal- ysis concluded that the mean decrease in pain intensity in most studies was only $30 \%$, whereas only $44 \%$ of the patients continued treatment for 7 to 24 months. Furlan et al (13) provided a more somber view of opioids concluding that strong opioids were more effective with pain relief and functional outcomes, even though drop-out rates averaged $33 \%$. Two Cochrane reviews $(15,16)$ showed unsatisfactory long-term results in managing neuropathic (15) and nociceptive pain (16). A recent systematic review and meta-analysis (9) of efficacy and safety of long-term opioid therapy for chronic non-cancer pain concluded that many patients discontinue long-term opioid therapy due to adverse events or insufficient pain relief. However, they also concluded that weak evidence suggests that oral opioids reduce pain long-term in the relatively small proportion of individuals with chronic non-cancer pain who continue treatment. Sandoval et al (18) in a systematic review of methadone found no randomized trials for long-term use of methadone and showed only limited evidence with observational reports.

Cepeda et al (17) performed a systematic review and meta-analysis of randomized clinical trials of tramadol and concluded that tramadol is more effective than placebo for the treatment of osteoarthritis when the pain is moderate. However, tramadol was only of limited benefit when the pain was severe.

Overall, the evidence supporting the long-term analgesic efficacy is weak at best based on the present evidence. In addition, not surprisingly, epidemiological

Table 4. The increase in therapeutic opioids use in the U.S. (mg/person) from 1997 to 2006.

\begin{tabular}{|l|c|c|c|c|c|c|c|c|c|c|c||}
\hline Type & $\mathbf{1 9 9 7}$ & $\mathbf{1 9 9 8}$ & $\mathbf{1 9 9 9}$ & $\mathbf{2 0 0 0}$ & $\mathbf{2 0 0 1}$ & $\mathbf{2 0 0 2}$ & $\mathbf{2 0 0 3}$ & $\mathbf{2 0 0 4}$ & $\mathbf{2 0 0 5}$ & $\mathbf{2 0 0 6}$ & $\begin{array}{c}\text { \% of Change } \\
\text { from 1997 }\end{array}$ \\
\hline Morphine & 22.20 & 24.01 & 24.50 & 28.11 & 31.72 & 36.95 & 44.30 & 51.55 & 54.20 & 63.03 & $184 \%$ \\
\hline Methadone & 1.94 & 2.60 & 3.47 & $5.14^{*}$ & 6.81 & 9.54 & 13.26 & 17.03 & 19.31 & 23.84 & $1,129 \%$ \\
\hline Oxycodone & 16.68 & 24.66 & 34.99 & 55.11 & 71.75 & 80.56 & 95.97 & 105.05 & 110.27 & 133.33 & $899 \%$ \\
\hline Hydrocodone & 32.49 & 38.93 & 43.57 & 50.83 & 56.15 & 67.77 & 80.44 & 86.70 & 92.90 & 107.49 & $231 \%$ \\
\hline Fentanyl & 0.28 & 0.34 & 0.39 & $0.53^{*}$ & 0.67 & 0.87 & 1.14 & 1.33 & 1.40 & 1.54 & $450 \%$ \\
\hline Total & $\mathbf{7 3 . 5 9}$ & $\mathbf{9 0 . 5 4}$ & $\mathbf{1 0 6 . 9 2}$ & $\mathbf{1 3 9 . 7 2}$ & $\mathbf{1 6 7 . 1}$ & $\mathbf{1 9 5 . 6 9}$ & $\mathbf{2 3 5 . 1 1}$ & $\mathbf{2 6 1 . 6 6}$ & $\mathbf{2 7 8}$ & $\mathbf{3 2 9 . 2 3}$ & $347 \%$ \\
\hline
\end{tabular}

* For year 2000 data is not available, the average of 1999 and 2001 was taken.

Source: Data taken from U.S. Drug Enforcement Administration. Automation of Reports and Consolidated Orders System (ARCOS); www.deadiversion.usdoj. gov/arcos/retail_drug_summary/index.html. Access date: 3/13/08

Adapted from Manchikanti and Singh (5). Therapeutic opioids: A ten-year perspective on the complexities and complications of the escalating use, abuse, and nonmedical use of opioids. Pain Physician 2008; 11:S63-S88. 


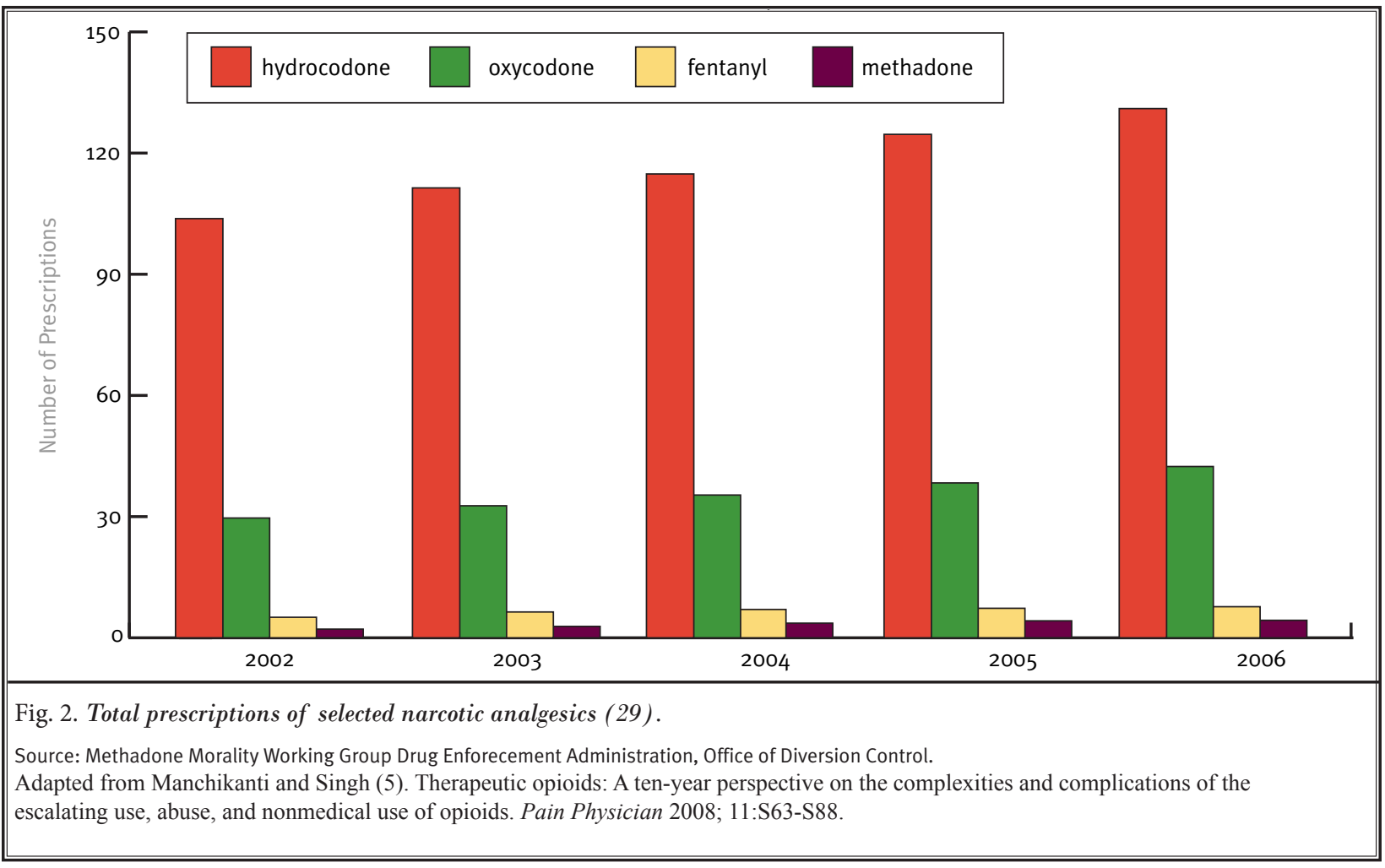

studies while positive with pain are less positive with regards to function and quality of life and report the failure of opioids to improve quality of life in chronic pain patients (20).

\subsection{Nonmedical Use of Prescription Drugs}

The National Survey on Drug Use and Health of 2006 (190) showed that an estimated 20.4 million or $8.3 \%$ of Americans, ages 12 or older were current (past month) illicit drug users. Among the illicit drugs, psychotherapeutic drugs which include prescription type pain relievers, tranquilizers, stimulants, and sedatives are included. Marijuana and hashish are the most commonly used illicit drugs with 14.8 million current users, or $6 \%$ of the U.S. population. Cocaine was used by 2.4 million, whereas hallucinogens were used in the past month by 1 million persons. However, surprisingly, next to marijuana, 7.0 million (2.8\%) persons aged 12 or older had used prescription-type psychotherapeutic drugs nonmedically in the past month. Of these, 5.2 million had used pain relievers, an increase from 4.7 million in 2005 (Table 5). The categories of nonmedical use of psychotherapeutics and pain relievers were well ahead of the illicit drug use of cocaine, hallucinogens, inhalants, methamphetamine, heroin, and LSD.

The increases for current nonmedical use of psychotherapeutics over a period of the last 10 years (1997 to 2006) was $162 \%$ compared to $33 \%$ for marijuana and hashish, and $61 \%$ for cocaine. Consequently, psychotherapeutics were the only ones that showed significant increases from 2002 to 2006, whereas, marijuana and cocaine were similar over a period of 5 years (5).

Statistics of new initiatives also continue to be grim with 2.6 million persons aged 12 or older using psychotherapeutic drugs nonmedically for the first time within the past year in 2006 (190). Similarly, numbers of new users for specific psychotherapeutics in 2006 were 2.2 million for pain relievers, 1.1 million for tranquilizers, 845,000 for stimulants, and 267,000 for sedative (Table 6).

Analysis of long-term statistics based on yearly use of illicit drugs are concerning (5). The past year use of illicit drugs in 2006 was 35.77 million or $4.5 \%$ of the population, whereas nonmedical use of psychotherapeutics for the past year in the 2006 survey was 16.287 
Table 5. Types of illicit drug use in the past month among persons aged 12 or older: Numbers in thousands, from 1997 to 2006.

\begin{tabular}{|c|c|c|c|c|c|c|c|c|c|c|c|}
\hline Drugs & 1997 & 1998 & 1999 & 2000 & 2001 & 2002 & 2003 & 2004 & 2005 & 2006 & $\begin{array}{c}\text { \% change } \\
\text { from } 1997 \\
\text { to } 2006\end{array}$ \\
\hline $\begin{array}{l}\text { Nonmedical Use of } \\
\text { Psychotherapeutics }\end{array}$ & $\begin{array}{c}2,665 \\
(1.2 \%)\end{array}$ & $\begin{array}{l}2,477 \\
(1.1 \%)\end{array}$ & $\begin{array}{c}3,952 \\
(1.8 \%)\end{array}$ & $\begin{array}{c}3,849 \\
(1.7 \%)^{\prime}\end{array}$ & $\begin{array}{l}4,811^{\mathrm{c}} \\
(2.1 \%)\end{array}$ & $\begin{array}{l}6,210^{\mathrm{a}} \\
(2.6 \%)\end{array}$ & $\begin{array}{c}6,336 \\
(2.7 \%)\end{array}$ & $\begin{array}{l}6,007^{\mathrm{b}} \\
\left(2.5 \%^{\mathrm{b}}\right)\end{array}$ & $\begin{array}{c}6,405 \\
(2.6 \%)\end{array}$ & $\begin{array}{l}6,991 \\
(2.8 \%)\end{array}$ & $162 \%$ \\
\hline Pain Relievers & -- & -- & $\begin{array}{c}2,621 \\
(1.2 \%)\end{array}$ & $\begin{array}{l}2,782 \\
(1.2 \%)\end{array}$ & $\begin{array}{l}3,497^{c} \\
(1.6 \%)\end{array}$ & $\begin{array}{l}4,377^{\mathrm{b}} \\
\left(1.9 \%^{\mathrm{a}}\right)\end{array}$ & $\begin{array}{l}4,693 \\
(2.0 \%)\end{array}$ & $\begin{array}{l}4,404^{\mathrm{b}} \\
\left(1.8 \%^{\mathrm{a}}\right)\end{array}$ & $\begin{array}{l}4,658^{\mathrm{a}} \\
(1.9 \%)\end{array}$ & $\begin{array}{l}5,220 \\
(2.1 \%)\end{array}$ & NA \\
\hline OxyContin ${ }^{\circ}$ & -- & -- & -- & -- & -- & -- & -- & $\begin{array}{c}325 \\
(0.1 \%)\end{array}$ & $\begin{array}{c}334 \\
(0.1 \%)\end{array}$ & $\begin{array}{c}276 \\
(0.1 \%)\end{array}$ & NA \\
\hline Tranquilizers & $\begin{array}{c}845 \\
(0.4 \%)\end{array}$ & $\begin{array}{c}655 \\
(0.3 \%)\end{array}$ & $\begin{array}{l}1,097 \\
(0.5 \%)\end{array}$ & $\begin{array}{l}1,000 \\
(0.4 \%)\end{array}$ & $\begin{array}{l}1,358^{c} \\
(0.6 \%)\end{array}$ & $\begin{array}{l}1,804 \\
(0.8 \%)\end{array}$ & $\begin{array}{l}1,830 \\
(0.8 \%)\end{array}$ & $\begin{array}{l}1,616 \\
(0.7 \%)\end{array}$ & $\begin{array}{c}1,817 \\
(0.7 \%)\end{array}$ & $\begin{array}{l}1,766 \\
(0.7 \%)\end{array}$ & $109 \%$ \\
\hline Stimulants & $\begin{array}{c}612 \\
(0.3 \%)\end{array}$ & $\begin{array}{c}633 \\
(0.3 \%)\end{array}$ & $\begin{array}{c}950 \\
(0.4 \%)\end{array}$ & $\begin{array}{c}788 \\
(0.4 \%)\end{array}$ & $\begin{array}{l}1,018 \\
(0.5 \%)\end{array}$ & $\begin{array}{l}1,218 \\
(0.5 \%)\end{array}$ & $\begin{array}{c}1,191 \\
(0.5 \%)\end{array}$ & $\begin{array}{l}1,189 \\
(0.5 \%)\end{array}$ & $\begin{array}{l}1,067 \\
(0.4 \%)\end{array}$ & $\begin{array}{c}1,191 \\
(0.5 \%)\end{array}$ & $95 \%$ \\
\hline Sedatives & $\begin{array}{c}187 \\
(0.1 \%)\end{array}$ & $\begin{array}{c}210 \\
(0.1 \%)\end{array}$ & $\begin{array}{c}229 \\
(0.1 \%)\end{array}$ & $\begin{array}{c}175 \\
(0.1 \%)\end{array}$ & $\begin{array}{c}306 \\
(0.1 \%)\end{array}$ & $\begin{array}{c}436 \\
(0.2 \%)\end{array}$ & $\begin{array}{c}294 \\
(0.1 \%)\end{array}$ & $\begin{array}{c}265 \\
(0.1 \%)\end{array}$ & $\begin{array}{c}272 \\
(0.1 \%)\end{array}$ & $\begin{array}{c}385 \\
(0.2 \%)\end{array}$ & $106 \%$ \\
\hline $\begin{array}{l}\text { Marijuana and } \\
\text { Hashish }\end{array}$ & $\begin{array}{l}11,109 \\
(5.1 \%)\end{array}$ & $\begin{array}{l}11,016 \\
(5.0 \%)\end{array}$ & $\begin{array}{l}10,458 \\
(4.7 \%)\end{array}$ & $\begin{array}{c}10,714 \\
(4.8)\end{array}$ & $\begin{array}{l}12,122^{c} \\
(5.4 \%)\end{array}$ & $\begin{array}{l}14,584 \\
(6.2 \%)\end{array}$ & $\begin{array}{l}14,638 \\
(6.2 \%)\end{array}$ & $\begin{array}{l}14,576 \\
(6.1 \%)\end{array}$ & $\begin{array}{l}14,626 \\
(6.0 \%)\end{array}$ & $\begin{array}{l}14,813 \\
(6.0 \%)\end{array}$ & $33 \%$ \\
\hline Cocaine & $\begin{array}{l}1,505 \\
(0.7 \%)\end{array}$ & $\begin{array}{l}1,750 \\
(0.8 \%)\end{array}$ & $\begin{array}{c}1,552 \\
(0.7 \%)\end{array}$ & $\begin{array}{c}1,213 \\
(0.5 \%)\end{array}$ & $\begin{array}{l}1,667^{c} \\
(0.7 \%)\end{array}$ & $\begin{array}{l}2,020^{\mathrm{a}} \\
(0.9 \%)\end{array}$ & $\begin{array}{c}2,281 \\
(1.0 \%)\end{array}$ & $\begin{array}{l}2,021^{\mathrm{a}} \\
(0.8 \%)\end{array}$ & $\begin{array}{c}2,397 \\
(1.0 \%)\end{array}$ & $\begin{array}{c}2,421 \\
(1.0 \%)\end{array}$ & $61 \%$ \\
\hline Total Illicit Drugs ${ }^{1}$ & $\begin{array}{l}13,904 \\
(6.4 \%)\end{array}$ & $\begin{array}{l}13,615 \\
(6.2 \%)\end{array}$ & $\begin{array}{l}13,829 \\
(6.3 \%)\end{array}$ & $\begin{array}{l}14,027 \\
(6.3 \%)\end{array}$ & $\begin{array}{l}15,910^{c} \\
(7.1 \%)\end{array}$ & $\begin{array}{l}19,522 \\
(8.3 \%)\end{array}$ & $\begin{array}{l}19,470 \\
(8.2 \%)\end{array}$ & $\begin{array}{l}19,071^{\mathrm{a}} \\
(7.9 \%)\end{array}$ & $\begin{array}{l}19,720 \\
(8.1 \%)\end{array}$ & $\begin{array}{l}20,357 \\
(8.3 \%)\end{array}$ & $46 \%$ \\
\hline
\end{tabular}

-- Not available.

a Difference between estimate and 2006 estimate is statistically significant at the 0.05 level.

b Difference between estimate and 2006 estimate is statistically significant at the 0.01 level.

c Difference between estimate and previous year estimate is statistically significant at the 0.01 level.

1 Illicit drugs include marijuana/hashish, cocaine (including crack), heroin, hallucinogens, inhalants, or prescription-type psychotherapeutics used nonmedically.

2 Nonmedical use of prescription-type psychotherapeutics includes the nonmedical use of pain relievers, tranquilizers, stimulants, or sedatives, and does not

include over-the-counter drugs.

Source: SAMHSA, Office of Applied Studies, National Survey on Drug Use and Health, 1995 to 2006.

Adapted from Manchikanti and Singh (5). Therapeutic opioids: A ten-year perspective on the complexities and complications of the escalating use, abuse, and nonmedical use of opioids. Pain Physician 2008; 11: S63-S88.

million compared to 15.172 million in 2005 and 14.643 million in 2004 , or $6.6 \%$ of the population aged 12 or older in 2006, 6.2\% in 2005, and 6.1\% in 2004 with significant increases (Table 7). Similarly, lifetime use of psychotherapeutics drugs has been increasing over the years with nonmedical use of psychotherapeutic increasing from $20 \%$ of the population in 2005 to $20.3 \%$ in 2006 or almost 50 million. A review of therapeutic opioids with a 10-year perspective on the complexities and complications of escalating use, abuse, and nonmedical use of opioids describes in detail the issues related to therapeutic opioid abuse (5).

A survey of American adults by USA Today and HBO (192) in 2006 found that:

- One in 5 adults have a close relative who is or was addicted to drugs or alcohol.

- Three-quarters of American adults who have a family member suffering from the disease of drug or alcohol addiction think addiction is a disease.

- Emotional and Devastating/Horrible are the words that were most often used to describe the effects of a family member's addition.

- Almost one of 10 of those who say a family member's addiction has had a major negative impact on their financial situation say they have had to take out a loan or run up credit card bills as a direct result of this addiction.

- About a fifth of those who say a family member's addiction has had a major negative impact on their marriage, family relationships, or emotional health say they sought professional counseling.

- One third of American adults who have a family member suffering from the disease of drug or alcohol addiction say the addiction has caused estrangement among family members.

- Almost half of U.S. adults who have a family 
Table 6. Past year initiates for illicit drugs from 1997 to 2006 (numbers in thousands).

\begin{tabular}{|c|c|c|c|c|c|c|c|c|c|c|c|}
\hline Drugs & 1997 & 1998 & 1999 & 2000 & 2001 & 2002 & 2003 & 2004 & 2005 & 2006 & $\begin{array}{c}\text { \% change } \\
\text { from } 1997 \\
\text { to } 2006\end{array}$ \\
\hline Pain Relievers ${ }^{2}$ & 1,316 & 1,548 & 1,810 & 2,268 & 2,400 & 2,320 & $2,456^{\mathrm{a}}$ & $2,422^{\mathrm{a}}$ & 2,193 & 2,150 & $63 \%$ \\
\hline Tranquilizers & 668 & 860 & 916 & 1,298 & 1,212 & 1,184 & 1,071 & 1,180 & 1,286 & 1,112 & $66 \%$ \\
\hline Stimulants & 553 & 648 & 706 & 808 & 853 & 783 & 715 & 793 & $647^{a}$ & 845 & $53 \%$ \\
\hline Sedatives & 120 & 147 & 164 & 191 & 225 & 209 & 194 & 240 & 247 & 267 & $123 \%$ \\
\hline Marijuana & 2,603 & 2,498 & 2,640 & 2,746 & 2,793 & 2,196 & 1,973 & 2,142 & 2,114 & 2,063 & $-21 \%$ \\
\hline Cocaine & 861 & 868 & 917 & 1,002 & 1,140 & 1,032 & 986 & 998 & 872 & 977 & $13 \%$ \\
\hline Heroin & 114 & 140 & 121 & 114 & 154 & 117 & 92 & 118 & 108 & 91 & $-20 \%$ \\
\hline
\end{tabular}

Note: 2002 to 2006 data is based on 2006 National Survey on Drug Use and Health Survey Report.

NOTE: Past year initiates are defined as persons who used the substance(s) for the first time in the 12 months prior to date of interview.

a Difference between estimate and 2006 estimate is statistically significant at the 0.05 level.

2 Nonmedical use of prescription-type psychotherapeutics includes the nonmedical use of pain relievers, tranquilizers, stimulants, or sedatives, and does not include over-the-counter drugs.

Source: SAMHSA, Office of Applied Studies, National Survey on Drug Use and Health, 2002, 2003, 2004, 2005, and 2006.

Adapted from Manchikanti and Singh (5). Therapeutic opioids: A ten-year perspective on the complexities and complications of the escalating use, abuse, and nonmedical use of opioids. Pain Physician 2008; 11:S63-S88.

Table 7. Types of illicit drug use in the past year among persons aged 12 or older from 1997 to 2006 (numbers in thousands).

\begin{tabular}{|c|c|c|c|c|c|c|c|c|c|c|c|}
\hline Drugs & 1997 & 1998 & 1999 & 2000 & 2001 & 2002 & 2003 & 2004 & 2005 & 2006 & $\begin{array}{c}\text { \% change } \\
\text { from } 1997 \\
\text { to } 2006 \\
\end{array}$ \\
\hline $\begin{array}{l}\text { Nonmedical Use of } \\
\text { Psychotherapeutics }\end{array}$ & $\begin{array}{l}6,111 \\
(2.8 \%)\end{array}$ & $\begin{array}{l}5,759 \\
(2.6 \%)\end{array}$ & $\begin{array}{l}9,220 \\
(4.2 \%)\end{array}$ & $\begin{array}{l}8,761 \\
(3.9 \%)\end{array}$ & $\begin{array}{l}11,102^{c} \\
\left(4.9 \%^{c}\right)\end{array}$ & $\begin{array}{l}14,680^{\mathrm{b}} \\
(6.2 \%)\end{array}$ & $\begin{array}{l}14,986^{\mathrm{b}} \\
(6.3 \%)\end{array}$ & $\begin{array}{l}14,643^{\mathrm{b}} \\
\left(6.1 \%^{\mathrm{b}}\right)\end{array}$ & $\begin{array}{l}15,172^{\mathrm{a}} \\
\left(6.2 \%^{\mathrm{a}}\right)\end{array}$ & $\begin{array}{l}16,287 \\
(6.6 \%)\end{array}$ & $167 \%$ \\
\hline Pain Relievers & -- & -- & $\begin{array}{c}6,582 \\
(3.0 \%) \\
\end{array}$ & $\begin{array}{c}6,466 \\
(2.9 \%) \\
\end{array}$ & $\begin{array}{r}8,353^{\mathrm{c}} \\
\left(3.7 \%^{\mathrm{c}}\right) \\
\end{array}$ & $\begin{array}{l}10,992^{\mathrm{b}} \\
\left(4.7 \%^{\mathrm{b}}\right)\end{array}$ & $\begin{array}{l}11,671^{\mathrm{a}} \\
(4.9 \%)\end{array}$ & $\begin{array}{l}11,256^{\mathrm{b}} \\
\left(4.7 \%^{\mathrm{b}}\right)\end{array}$ & $\begin{array}{l}11,815^{\mathrm{a}} \\
(4.9 \%)\end{array}$ & $\begin{array}{l}12,649 \\
(5.1 \%)\end{array}$ & NA \\
\hline OxyContin ${ }^{\bullet}$ & -- & -- & -- & -- & -- & -- & -- & $\begin{array}{l}1,213 \\
(0.5 \%)\end{array}$ & $\begin{array}{l}1,226 \\
(0.5 \%)\end{array}$ & $\begin{array}{l}1,323 \\
(0.5 \%)\end{array}$ & NA \\
\hline Tranquilizers & $\begin{array}{l}2,122 \\
(1.0 \%)\end{array}$ & $\begin{array}{l}1,940 \\
(0.9 \%)\end{array}$ & $\begin{array}{l}2,728 \\
(1.2 \%)\end{array}$ & $\begin{array}{l}2,731 \\
(1.2 \%)\end{array}$ & $\begin{array}{l}3,673^{c} \\
\left(1.6 \%{ }^{c}\right)\end{array}$ & $\begin{array}{c}4,849 \\
(2.1 \%)\end{array}$ & $\begin{array}{l}5,051 \\
(2.1 \%)\end{array}$ & $\begin{array}{l}5,068 \\
(2.1 \%)\end{array}$ & $\begin{array}{l}5,249 \\
(2.2 \%)\end{array}$ & $\begin{array}{l}5,058 \\
(2.1 \%)\end{array}$ & $138 \%$ \\
\hline Stimulants & $\begin{array}{l}1,687 \\
(0.8 \%)\end{array}$ & $\begin{array}{l}1,489 \\
(0.7 \%)\end{array}$ & $\begin{array}{c}2,291 \\
(1.0 \%)\end{array}$ & $\begin{array}{l}2,112 \\
(0.9 \%)\end{array}$ & $\begin{array}{l}2,486^{c} \\
(1.1 \%)\end{array}$ & $\begin{array}{c}3,181 \\
(1.4 \%)\end{array}$ & $\begin{array}{l}2,751^{\mathrm{b}} \\
\left(1.2 \%^{\mathrm{a}}\right)\end{array}$ & $\begin{array}{l}2,918^{\mathrm{a}} \\
(1.2 \%)\end{array}$ & $\begin{array}{l}2,771^{\mathrm{b}} \\
\left(1.1 \%^{\mathrm{b}}\right)\end{array}$ & $\begin{array}{c}3,394 \\
(1.4 \%)\end{array}$ & $101 \%$ \\
\hline Sedatives & $\begin{array}{c}638 \\
(0.3 \%)\end{array}$ & $\begin{array}{c}522 \\
(0.2 \%)\end{array}$ & $\begin{array}{c}631 \\
(0.3 \%)\end{array}$ & $\begin{array}{c}611 \\
(0.3 \%)\end{array}$ & $\begin{array}{c}806 \\
(0.4 \%) \\
\end{array}$ & $\begin{array}{c}981 \\
(0.4 \%)\end{array}$ & $\begin{array}{c}831 \\
(0.3 \%)\end{array}$ & $\begin{array}{c}737 \\
(0.3 \%)\end{array}$ & $\begin{array}{c}750 \\
(0.3 \%)\end{array}$ & $\begin{array}{c}926 \\
(0.4 \%)\end{array}$ & $45 \%$ \\
\hline $\begin{array}{l}\text { Marijuana and } \\
\text { Hashish }\end{array}$ & $\begin{array}{l}19,446 \\
(9.0 \%)\end{array}$ & $\begin{array}{l}18,710 \\
(8.6 \%)\end{array}$ & $\begin{array}{l}19,102 \\
(8.6 \%)\end{array}$ & $\begin{array}{l}18,589 \\
(8.3 \%)\end{array}$ & $\begin{array}{l}21,086^{c} \\
\left(9.3 \%^{c}\right)\end{array}$ & $\begin{array}{c}25,755 \\
\left(11.0 \%^{\mathrm{a}}\right)\end{array}$ & $\begin{array}{c}25,231 \\
(10.6 \%)\end{array}$ & $\begin{array}{c}25,451 \\
(10.6 \%)\end{array}$ & $\begin{array}{c}25,375 \\
(10.4 \%)\end{array}$ & $\begin{array}{c}25,378 \\
(10.3 \%)\end{array}$ & $31 \%$ \\
\hline Cocaine & $\begin{array}{c}4,169 \\
(1.9 \%)\end{array}$ & $\begin{array}{c}3,811 \\
(1.7 \%)\end{array}$ & $\begin{array}{c}3,742 \\
(1.7 \%)\end{array}$ & $\begin{array}{c}3,328 \\
(1.5 \%)\end{array}$ & $\begin{array}{l}4,186^{c} \\
\left(1.9 \%^{c}\right)\end{array}$ & $\begin{array}{l}5,902 \\
(2.5 \%)\end{array}$ & $\begin{array}{l}5,908 \\
(2.5 \%)\end{array}$ & $\begin{array}{l}5,658 \\
(2.4 \%)\end{array}$ & $\begin{array}{c}5,523 \\
(2.3 \%)\end{array}$ & $\begin{array}{l}6,069 \\
(2.5 \%)\end{array}$ & $46 \%$ \\
\hline Total Illicit Drugs ${ }^{1}$ & $\begin{array}{c}24,189 \\
(11.2 \%)\end{array}$ & $\begin{array}{c}23,115 \\
(10.6 \%)\end{array}$ & $\begin{array}{c}25,402 \\
(11.5 \%)\end{array}$ & $\begin{array}{c}24,535 \\
(11.0 \%)\end{array}$ & $\begin{array}{c}28,409^{c} \\
\left(12.6 \%^{c}\right)\end{array}$ & $\begin{array}{c}35,132 \\
(14.9 \%)\end{array}$ & $\begin{array}{c}34,993 \\
(14.7 \%)\end{array}$ & $\begin{array}{c}34,807 \\
(14.5 \%)\end{array}$ & $\begin{array}{c}35,041 \\
(14.4 \%)\end{array}$ & $\begin{array}{c}35,775 \\
(14.5 \%)\end{array}$ & $48 \%$ \\
\hline
\end{tabular}

Note: 2002 to 2006 data is based on 2006 National Survey on Drug Use and Health Survey Report.

Figures in () indicate percentage.

-- Not available.

a Difference between estimate and 2006 estimate is statistically significant at the 0.05 level. b Difference between estimate and 2006 estimate is statistically significant at the 0.01 level. c Estimate is statistically different than previous year 1 Illicit drugs include marijuana/hashish, cocaine (including crack), heroin, hallucinogens, inhalants, or prescription-type psychotherapeutics used nonmedically. 2 Nonmedical use of prescription-type psychotherapeutics includes the nonmedical use of pain relievers, tranquilizers, stimulants, or sedatives, and does not include over-the-counter drugs.

Source: SAMHSA, Office of Applied Studies, National Survey on Drug Use and Health, 1995 to 2006.

Adapted from Manchikanti and Singh (5). Therapeutic opioids: A ten-year perspective on the complexities and complications of the escalating use, abuse, and nonmedical use of opioids. Pain Physician 2008; 11:S63-S88. 
member suffering from the disease of drug or alcohol addiction say their family member has never sought treatment. Of those whose family member has sought treatment, 3 out of 10 only sought treatment after intervention.

- Of those whose family member sought treatment, almost half say the family member relapsed and almost one out of 10 say there was no improvement at all.

- Only 3 out of 10 respondents say their addicted family member consulted with a medical doctor or other medical professional specializing in the treatment of addiction.

- Over half of the respondents say their addicted family member was never evaluated for psychological illness.

The latest Center on Addiction and Substance Abuse (CASA) report (193) also presented alarming statistics finding that at 11 million high school students $(80 \%)$ and 5 million middle school students (44\%) attended drug-infested schools, where they have personally witnessed illegal drug use, illegal drug dealing, and students high on the grounds of the school. More than one in $3(37 \%)$ teens say they can buy marijuana within a day, and $17 \%$ say they can buy marijuana within an hour. Even more concerning, students who identify themselves as "popular" and attended a drug-infested school, were 5 times more likely to get drunk in a typical month, and are much more likely to abuse prescription and illegal drugs. It is particularly concerning that $28.9 \%$ of pharmacists have been robbed within the past 5 years, and $20.9 \%$ no longer stock certain controlled drugs in order to prevent future robberies.

\subsubsection{Physician Survey Highlights}

In a 2006 survey (194) of 248 primary care physicians $(P C P)$ regarding their attitudes toward the prescribing of opioids for chronic pain, their major concerns included prescription drug abuse (84.2\%), addiction $(74.9 \%)$, adverse effects $(68 \%)$, tolerance $(60.7 \%)$, and medication interaction (32\%). A majority were comfortable prescribing opioids for cancer pain, but they were less comfortable prescribing opioids for back pain or for patients with a history of drug or alcohol abuse. Only $6.9 \%$ reported obtaining a urine screen prior to initiating opioid therapy, and only $15 \%$ performed urine screens on patients currently on opioids.

Similarly, in another survey (195) of 111 primary care attendings, residents, and nurse practitioners in
8 community clinics, the PCPs reported that $37.5 \%$ of their adult patients in a given week had chronic pain issues. But, they attributed these problems with pain care to patient related factors such as self-management and abuse issues instead of provider or practice system factors.

In a study published in 2007 (196) evaluating long-term opioid contract use for chronic pain management in primary care practice, illustrating a 5-year experience, contracts were discontinued in approximately $40 \%$ of the patients. However, only $17 \%$ were cancelled for substance abuse and noncompliance and $20 \%$ discontinued the contract voluntarily. In this population, urine toxicology screens were obtained in $42 \%$ of patients of whom $38 \%$ were positive for illicit substances. This report reveals a lack of a systematic approach to opioid administration and monitoring in primary care practices. In another article, it was questioned with regards to the dilemmas experienced when prescribing opioids in general practice (197). There have also been publications with regards to designing a primary care-based chronic pain management program from a scientific basis (198) and guidance for contractual approaches (198). Further, issues related to chronic pain patients, adherence monitoring, etc., have been described in detail in chronic pain management settings (1).

A CASA survey of 979 physicians regarding the diversion and abuse of controlled prescription drugs showed that physicians perceive the 3 main mechanisms of diversion to be doctor shopping, patient deception, or manipulation of doctors, and forged or altered prescriptions (179). Further, a good majority of physicians believe that patients account for the bulk of the diversion problem. In addition, less than $20 \%$ of surveyed physicians received any medical school training in identifying prescription drug diversion, and less than $40 \%$ received any training in medical school in identifying prescription drug abuse and addiction. It was also shown that $43 \%$ of physicians do not ask about prescription drug abuse when taking a patient's health history and over $70 \%$ of physicians have refrained from prescribing controlled drugs due to concerns that a patient may become addicted to them.

\subsubsection{Pharmacist Survey Highlights}

There have been no new studies of pharmacists since the CASA study of 2005 (180). At that time, $28.4 \%$ of pharmacists did not regularly validate the prescribing physician's DEA number when dispensing controlled drugs; one in $10(10.5 \%)$ rarely or never do 
so. Sixty-one percent did not regularly ask if the patient is taking any other controlled drugs, $25.8 \%$ rarely or never do. Seventy-eight percent become "somewhat or very" concerned about diversion or abuse when a patient asks for a controlled drug by name; $83.1 \%$ have refused to dispense a controlled drug in the past year because of suspicions of diversion; and $51.8 \%$ believed that patients account for the bulk of the diversion problems.

\subsubsection{Drug Abuse Warning Network (DAWN) Reports}

The Drug Abuse Warning Network (DAWN) (199) examined the involvement of opiates and deaths related to drug misuse. Nearly 1.3 million emergency department (ED) visits in 2005 were associated with drug misuse/abuse (200). Nonmedical use of pharmaceuticals was involved in nearly a half million of these ED visits with opioids constituting over 196,000 visits (an increase over 2004 of $24 \%$ ). There was a $92 \%$ increase in visits due to hydromorphone products (most likely due to Palladone overdoses), and a $29 \%$ increase in methadone visits. Two-thirds or more of ED visits associated with opiates/opioids, benzodiazepines, and muscle relaxants involved multiple drugs, and alcohol was one of the other drugs in about a quarter of such visits. Toxic effects were reported in $10 \%$ of visits. The DAWN data also showed that opioids account for more overdose deaths in the United States than either heroin or cocaine.

In 2006, young adults aged 18 to 25 demonstrated rates of current use of illicit drugs to be higher $(19.8 \%)$ than for youths aged 12 to 17 and adults aged 26 or older, with $16.3 \%$ using marijuana, $6.4 \%$ using psychotherapeutics nonmedically, $2.2 \%$ using cocaine, and $1.7 \%$ using hallucinogens (Fig. 3).

\subsubsection{Healthcare and Social Costs}

Unfortunately, the current emphasis on pain assessment as the fifth vital sign has resulted in the potential overmedication of a group of patients $(139,140)$. Prescription drug abuse inflicts enormous costs on our society. The mortality from opioids cannot be ignored $(201,202)$. In a study of the Centers for Disease Control (CDC) (203), increasing deaths were found from opioid analgesics in the United States. Unintentional drug poisoning mortality rates increased an average of $5.3 \%$ per year from 1979 to 1990 and $18.1 \%$ per year from 1990 to 2002 . The rapid increase during the 1990s reflects the rising number of deaths attributed to opioids and unspecified drugs. Between 1999 and 2002 (the last date for which the information is available), the number of opioid analgesic poisonings on death certificates increased $91.2 \%$, while heroin and cocaine poisonings increased $12.4 \%$ and

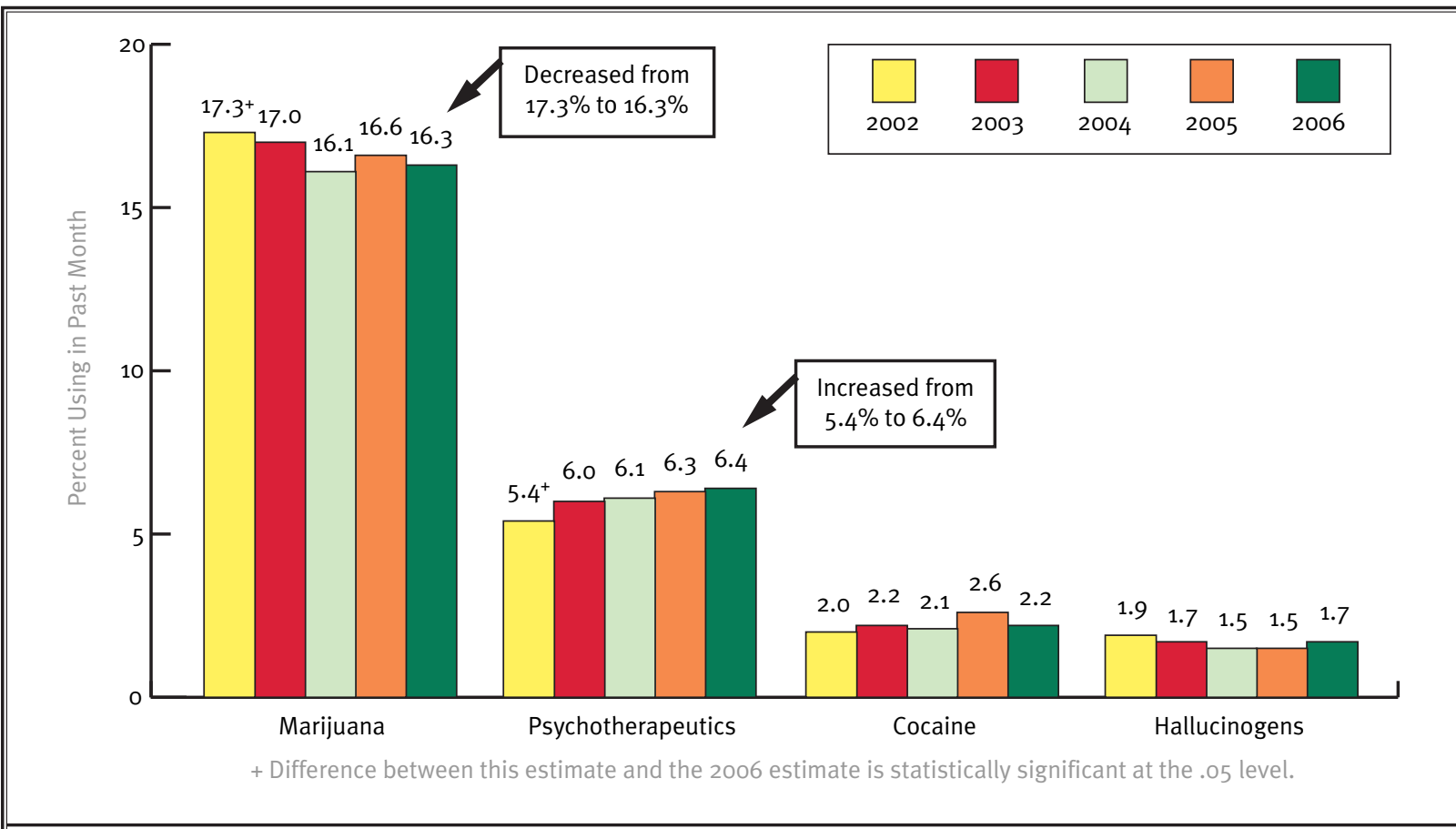

Fig. 3. Past month use of selected illicit drugs among young adults aged 18 to 25: 2002 - 2006 (1). 
$22.8 \%$, respectively. In 2002 , opioid analgesic poisoning was listed in 5,528 deaths - more than either heroin or cocaine. The follow-up evaluation in 2007 (200) revealed that unintentional drug poisoning was second only to motor vehicle crashes as a cause of death from unintentional injury in the United States. This updated study showed the number of unintentional poisoning deaths increased from 12,186 in 1999 to 20,950 in 2004, with an increase of age-adjusted rate of $62.5 \%$ from 4.4 per 100,000 population in 1990 to 7.1 in 2004. The highest rate of deaths (59.6) in 2004 were among persons aged 35 to 54 years. Among the opioids, methadone has been implicated in more unintentional poisoning deaths than any other opioid (176, 177,204-207).

Methadone-related deaths from 1999 to 2004 increased $390 \%$, whereas the number of all poisoning deaths increased $54 \%$ (203). In addition, methadone mentions in poisoning deaths increased from $4 \%$ of all poisoning deaths to $13 \%$ of all poisoning deaths. The increase in methadone deaths was $29 \%$ from 2002 to 2004 , in contrast to all poisoning deaths of $6 \%$ during the same period (Table 8). Further, persons aged 15 to 24 years contributed to the largest increases of deaths with a rate of 11 times to that of 99 in 2004, even though most methadone deaths were in persons aged 35 to 44 and 45 to 54 years of age. However, reassessment of methadone mortality in 2007 also showed increasing use, misuse, diversion, and abuse $(208,209)$. This led to a stricter warnings about methadone by the FDA (210).

\subsection{Substance Abuse in Chronic Pain}

The central question when prescribing opioids for chronic, non-cancer pain is how best to balance the risk of opioid abuse with the pain relief provided by these medications $(7,159)$.

A prospective cohort study of 196 opioid treated, chronic, non-cancer pain patients identified predictors of opioid misuse (160). Misuse was defined as having: negative urine toxicologic screen (UTS) for prescribed opioids, UTS positive for controlled substances not prescribed, procurement of opioids from multiple providers, diversion of opioids, prescription forgery, or, UTS positive for stimulants. The strongest predictors of misuse were the self-reported histories of previous alcohol or cocaine abuse, or previous criminal drug or alcohol-related convictions. Demographics such as gender, race, literacy, disability, and socioeconomic status were not associated with misuse.

The Veterans Administration looked at longitudinal administrative data from 2000 to 2005 (15,000 patients), and found that nonopioid substance abuse (such as alcohol) was the strongest predictor of opioid abuse (211). Mental health disorders were moderately strong predictors; the incidence of mental health disorders was much higher than the prevalence of nonopioid substance abuse ( $45.3 \%$ vs $7.6 \%$ ), suggesting that mental health disorders were indicative of a higher risk. Males, younger adults, and individuals with greater days supply of prescription opioids were more likely to develop opioid abuse. To look at the issue from the other side, a representative sample of

Table 8. Number of poisoning deaths in which specific narcotic substances are mentioned, 1999 to 2004.

\begin{tabular}{|l|c|c|c|c|c|c|c|c|}
\hline \multicolumn{1}{|c|}{ Substance } & $\mathbf{1 9 9 9}$ & $\mathbf{2 0 0 0}$ & $\mathbf{2 0 0 1}$ & $\mathbf{2 0 0 2}$ & $\mathbf{2 0 0 3}$ & $\mathbf{2 0 0 4}$ & $\begin{array}{c}\text { 1999-2004 } \\
\text { \% change }\end{array}$ & $\begin{array}{c}\mathbf{2 0 0 3 - 2 0 0 4} \\
\text { \% change }\end{array}$ \\
\hline $\begin{array}{l}\text { Poisoning by all Narcotics and } \\
\text { Psychodysleptics }\end{array}$ & 9,995 & 10,173 & 11,480 & 14,247 & 15,731 & 16,735 & 68.1 & 6.4 \\
\hline Opium & 4 & 2 & 5 & 3 & 4 & 1 & -75.0 & -75.0 \\
\hline Heroin & 1,964 & 1,846 & 1,782 & 2,091 & 2,080 & 1,881 & -4.2 & -9.6 \\
\hline Other Opioids & 2,757 & 2,932 & 3,484 & 4,431 & 4,877 & 5,242 & 90.1 & 7.5 \\
\hline Methadone & 786 & 988 & 1,456 & 2,360 & 2,974 & 3,849 & 389.7 & 29.4 \\
\hline Other Synthetic Narcotics & 732 & 784 & 962 & 1,301 & 1,406 & 1,668 & 127.9 & 18.6 \\
\hline Cocaine & 3,832 & 3,565 & 3,840 & 4,612 & 5,212 & 5,461 & 42.5 & 4.8 \\
\hline Other Narcotics & 2,902 & 2,880 & 2,881 & 3,143 & 3,117 & 2,761 & -4.9 & -11.4 \\
\hline Cannabis & 37 & 41 & 37 & 50 & 61 & 99 & 167.6 & 62.3 \\
\hline LSD & 3 & 3 & 2 & 0 & 1 & 1 & -66.7 & 0.0 \\
\hline Other & 9 & 8 & 7 & 5 & 6 & 5 & -44.4 & -16.7 \\
\hline
\end{tabular}

Note: Substance-specific data are not additive because of death.

Source: National Center for Health Statistics, National Vital Statistics System 
390 patients from 2 methadone maintenance treatment programs (MMTP) reveled that 37\% of these patients suffered from severe, chronic pain (212). Correlates of chronic pain included age (odds ratio [OR] 2.08), chronic illness (OR 1.88), and lifetime psychiatric illness (OR 1.77).

Fleming et al (189) in a sample of primary care patients found that the frequency of opioid use disorders was 4 times higher in patients receiving opioid therapy compared to nonopioid therapy patients. They also showed that DSM-IV evidence of opioid use disorder was seen in $9.7 \%$ of patients, 4 times higher than the reported general population, and $24 \%$ of urine drug testings were positive for illicit drugs.

Even though occasional studies (213) and proponents claim extremely low levels of opioid abuse, opioids are by far the most abused drugs, especially in chronic pain management settings. Numerous investigations have illustrated drug abuse in $18 \%$ to $41 \%$ in patients receiving opioids for chronic pain (1-5, 10,146-163,214-216).

Martell et al (10) in a systematic review of opioid treatment for chronic back pain, estimated the prevalence of lifetime substance use disorders to range from $36 \%$ to $56 \%$, with a $43 \%$ current substance use disorder rate. Further, aberrant medication-taking behaviors ranged from $5 \%$ to $24 \%$.

The abuse of drugs in chronic pain patients may also include illicit drugs in conjunction with controlled substances. Multiple investigators have studied the issue of illicit drug use in chronic pain patients receiving controlled substances $(146,158,160-163)$. The results showed that illicit drug use in patients without controlled substance abuse was found in $14 \%$ to $16 \%$ of patients and illicit drug use in patients with controlled substance abuse was present in $34 \%$ of the patients $(148,150,151)$. Illicit drug use was significant in chronic pain patients in general, but illicit drug use was similar in patients using either long-acting or short-acting opioids (161). In other evaluations, it was shown that adherence monitoring will in fact decrease controlled substance abuse and illicit drug use $(158,163)$.

Along with the increase of prescriptions for controlled drugs from 1992 to 2002 of $154 \%$ (173175,215-218), there was also a $90 \%$ increase in the number of people who admitted abusing controlled prescription drugs (219). Studies also evaluated opioid abuse in the insured population of the United States (218). Opioid abuse was determined to be present in 6.7 to 8 per 10,000 persons insured however, opioid abusers presented with multiple comorbidities and expenses 8 times higher than for non-abusers $(\$ 15,884$ vs $\$ 1,830$ ).

\subsection{Economic Impact}

The cost of opioid abuse is enormous ranging as high as $\$ 300$ billion a year as per the estimates of the White House Budge Office. The White House Office of National Drug Control Policy, a component of the Executive Office of the President, established by the Anti-Drug Abuse Act of 1990, has been spending $\$ 12$ to $\$ 13$ billion each year (2).

A study by the Office of Management and Budget estimated drug abuse costs to the United States at $\$ 300$ billion a year, including government anti-drug programs and the costs of crime, healthcare, accidents, and lost productivity. In the Aid to Family with Dependent Children (AFDC), Medicaid and food stamp programs, the incidence of drug abuse varies from $9.4 \%$ to $16.4 \%(218)$.

\subsection{Drug Diversion}

Drugs can be diverted from their lawful purpose to illicit use at any point in the pharmaceutical manufacturing and distribution process. The diversion of prescription drugs among adults is typically described to occur through one of the following: doctor shopping, illegal internet pharmacies, drug theft, prescription forgery, and illicit prescriptions by physicians. Youths typically acquire drugs by stealing from their relatives or buying from classmates who sell their legitimate prescriptions.

For the SAMHSA surveys $(190,191)$, nonmedical users of prescription-type psychotherapeutic drugs were asked questions regarding how they obtained the drugs they recently used nonmedically. In both 2005 and 2006, over half of the nonmedical users of prescription-type pain relievers, tranquilizers, stimulants, and sedatives said they obtained the drugs they used most recently "from a friend or relative for free." A follow-up question added in 2006 asked these respondents where their friend or relative had obtained the drugs. In $80.7 \%$ of the cases, the individuals indicated that their friend or relative had obtained the drugs from just one doctor. Only $1.6 \%$ reported that the friend or relative had bought the drug from a drug dealer or other stranger (Fig. 4).

As long as long-acting forms of opioids can be converted into rapid-onset drugs, there will be a push to divert and abuse these medications (221). In 
the wake of the OxyContin abuse scandals, the FDA has added warning labels to extended release formulations, admonishing against crushing and chewing tablets, which may have led to increased experimentation and abuse (222). The ease with which an active ingredient can be extracted form the parent medication has been seen as related to the medication's abuse potential; unfortunately, the pharmacy industry currently lacks standards to assess the tamper-resistance of a formulation, which makes it difficult to compare different formulations from different manufacturers. Katz and colleagues (223) have proposed 4 components of extractability: ease of extraction, purity of extract, efficiency of extraction, and potency of extract. They then developed a rating system, but concluded that more work needed to be done on the system before it could be used as an industry standard.

Doctor shopping by drug abusers is one of the most common ways of getting illegal controlled substances (224). Generally, this term refers to the visit by an individual — who may or may not have legitimate medical needs-to several doctors, each of whom writes a prescription for a controlled substance. The individual will visit several pharmacies, receiving more of the drug than intended by any single physician, typically for the purpose of feeding an addiction. Other illegal activities may include forged prescriptions and "pill mills" (facilities that prescribe large volumes of opioids without legitimate purpose, often for cash).

Illegal internet pharmacies have been available since about 1999. MarkMonitor, a company that analyzes online brands, estimates that consumers may be spending $\$ 4$ billion annually on prescription medicines at uncertified online websites linked to spam emails (225). Of the 3,160 sites identified in the report, a third are ranked by the Alexa website tracking service as high volume sites and had an average of 32,000 visitors a day. MarkMonitor estimated that if just $0.5 \%$ of customers purchased on average $\$ 70$ worth of medications, these ranked sites alone would earn $\$ 4$ billion a year.

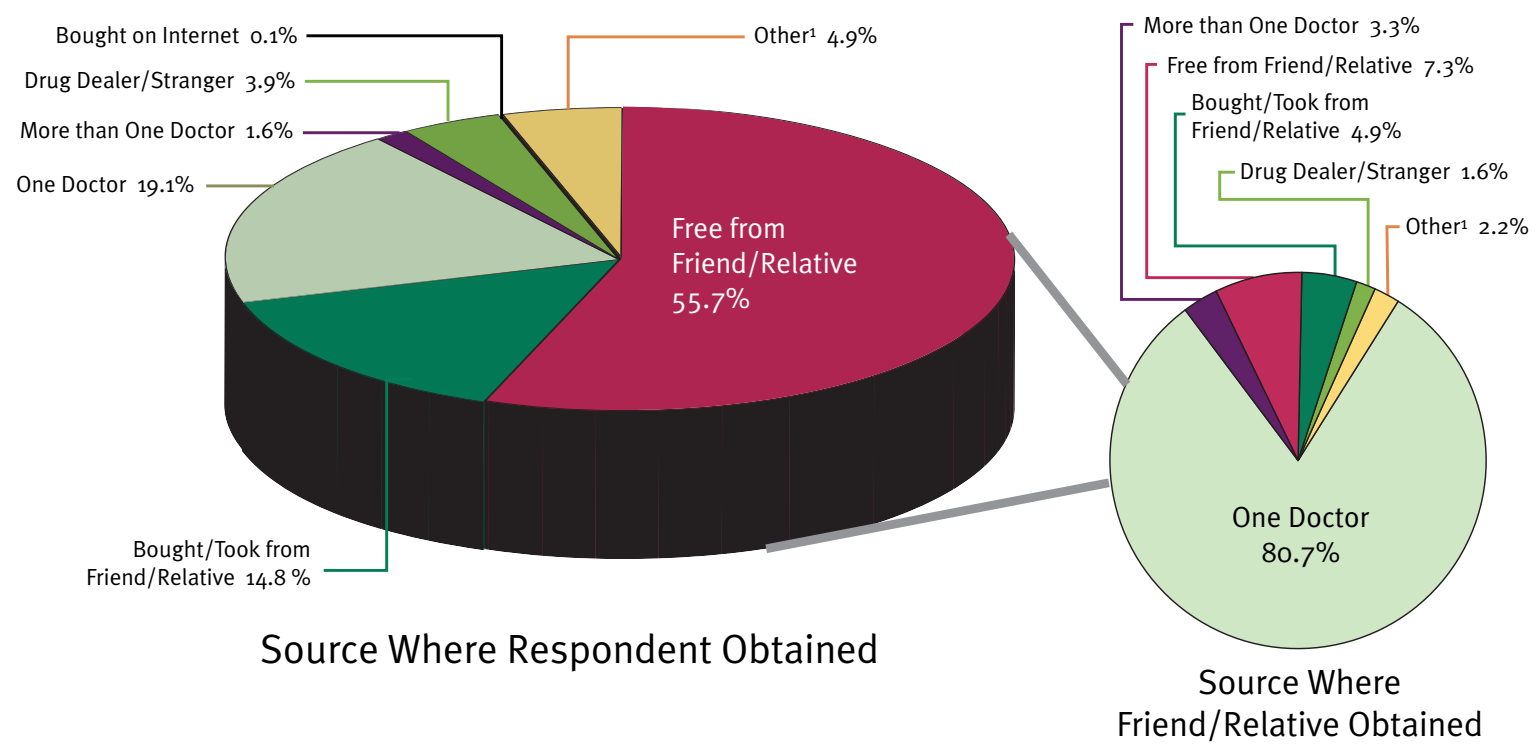

Note: Totals may not total to $100 \%$ because of rounding or because suppressed estimates are not shown.

'The Other category includes the sources: "Wrote Fake Prescription," "Stole from Doctor's Office/Clinic/Hospital/Pharmacy," and "Some Other Way."

Fig.4. Where pain relievers were obtained for most recent nonmedical use among past year users aged 12 or older: 2006 (1). Source: Abuse and Mental Health Services Administration (2007) (190). Results from the 2006 National Survey on Drug Use and Health: National Findings. 


\subsection{Controlling Diversion and Abuse}

For nearly 100 years, the laws governing the prescribing of medications with addictive potential (as described in the Harrison Narcotics Act of 1914) worked relatively well to control the access of these medicines while at the same time controlling their misuse. However, recent technologic developments, such as internet prescribing, have loosened the controls and increased the rate of diversion and abuse (226).

\subsubsection{Drug Enforcement Administration}

The Drug Enforcement Adminstration (DEA), as an agency within the United States Department of Justice, is the lead federal law enforcement agency responsible for enforcing the Controlled Substance Act (CSA). In cooperation with state authorities and other federal agencies, the DEA is responsible for preventing the diversion of controlled substances for illicit purposes. However, the DEA must comply with international treaties to the extent that they are not in conflict with constitutional provisions; it must also work closely with foreign, state, and local governments. The DEA has increased its monitoring of internet prescription drug sales. DEA investigations, enforcement, and intelligence programs have started to work more closely with other federal, state, and local agencies to target individuals and organizations involved in diversion and abuse of controlled prescription drugs.

High-profile arrests and prosecutions focus physicians' attention on the risks entailed in prescribing controlled substances in general, and have the specific effect of increasing physicians' and pharmacists' reluctance to prescribe, stock, or dispense opioid analgesics (227). However, a study published in 2006 looked at DEA arrest records in an effort to gauge the actual risk of DEA action (228). The review of the arrests and administrative actions of the DEA during fiscal year 2003 and 2004 showed that of the 963,385 physician registrants, there were 557 investigations with 6 civil fines, 22 letters of admonition, 21 administrative hearings, 34 license revocations, and 45 arrests.

\subsubsection{State Laws and Regulations}

Neither the DEA nor the federal government has the authority to regulate medical practice; this is the sole responsibility of the state government. States can require that a drug prescription be filled within a specified amount of time after it is written, and they can classify drugs at a higher level of abuse risk than the CSA schedule or place the drug on a state controlled substance list if not on the CSA list. State policies may conflict with or hamper the implementation of current treatment guidelines for the management of pain by limiting the amounts of opioid medications that can be prescribed, requiring special governmentissued prescription forms, using outdated terminology, considering opioids only as the treatment of last resort, and suggesting incorrectly that the therapeutic use of opioids hastens death (229). State medical boards can address physician concerns about regulatory scrutiny and promote the balance between opioid benefits and risks. Before 1989, only a few state medical boards developed policies governing the use of controlled substances (230). Since then, 41 states have adopted such policies, which include regulations that have the force of law, as well as guidelines and policy statements.

\subsubsection{Prescription Drug Monitoring Programs}

States began to address the misuse and abuse of prescription medications in the 1940 s by creating programs to monitor the dispensing of prescription drugs (3). These early programs required physicians to use special multiple-copy, 2- or 3-part prescription order forms, with a copy sent to a state monitoring program, and they only monitored Schedule II drugs. By 1999, 15 states had adopted prescription drug monitoring programs; but they were quite diverse. By the 1990s some programs were able to initiate electronic reporting, but, paper or electronic, most still used a variety of triggers such as number of prescriptions written or volume of medications prescribed to "flag" physicians or patients for further investigation. Kentucky established the Kentucky All Scheduled Prescription Electronic Reporting program (KASPER), an effective program that was limited by the 7 border states that surround Kentucky, allowing patients to take their prescriptions across state lines to thwart the program.

President Bush signed the National All Scheduled Prescription Electronic Reporting (NASPER) Act on August 11, 2005, making it the only statutorily authorized program to assist states in combating prescription drug abuse of controlled substances through a PDMP, and authorizing the U.S. Department of Health and Human Services (HHS) to award grants to States to construct prescription drug monitoring programs (PDMPs) and enhance communications between existing ones. Unfortunately, funding has not been provided for this activity (3).

A review of monitoring opioid adherence in chronic pain patients describes PDMPs (159). However, the effect and effectiveness of PDMPs is difficult to ascertain. The Medical Expenditure Panel survey showed 
an effect from prescription drug monitoring programs on opioid prescriptions with $3 \%$ of people in a nonPDMP state purchased at least one Schedule II analgesic, compared to $1.6 \%$ in states that had a PDMP. A number of techniques, instruments, and tools have been described to monitor controlled substance use and abuse (159). Even though multiple factors may be involved in drug misuse and abuse, no single instrument or assessment method has universal evaluative or predictive utility. Thus, multiple techniques and tools are available, and have been used to monitor adherence. These include various screening tests, urine drug testing, and prescription monitoring programs. Each of these methods have some relative validity and utility in assessing patterns of drug use, misuse, abuse, and/or the potential occurrence of addiction. Consequently, it is important for the clinician to determine whether to assess compliance, misuse, abuse, and/or addiction, so that the appropriate evaluative methods can be employed.

\subsection{Pharmacological Considerations}

Opioids are analgesics compounds that attach to and modulate ascending and descending pain related pathways (231). Opioids may be classified by their function as agonists, mixed agonists-antagonists, or antagonists, and by their actions at opioid receptors, mu, kappa, and delta $(231,232)$. Compounds can have differing degrees of affinity and efficacy at these various receptors (233).

\subsection{Opioid Pharmacology}

Opiates are naturally occurring alkaloids, such as morphine from the opium poppy seed. Opioid is the term used broadly to describe all compounds that exert activity at the opioid receptor. The term narcotic derives from the Greek word for stupor (227).

\subsubsection{Opioid Receptors}

There are opioid receptors within the central nervous system as well as throughout the peripheral tissues. These receptors are normally stimulated by endogenous peptides (endorphins, enkephalins, and dynorphins) produced in response to noxious stimulation. In addition, peripherally acting opioids (234) and combination of opioid analgesics have been described (235). Table 9 provides opioid receptors, related indigenous peptides, agonists, agonist/antagonist, and antagonists.

The opioid receptors were discovered in 1972, and the first endogenous opioid (enkephalin) was discovered in 1975. Their location in the CNS allows them to function as neurotransmitters, altering hormone secretion, thermoregulation, and cardiovascular control.

Opioids are classified by their action. These agents exhibit varying degrees of receptor affinity and efficacy, and can be pure agonist, agonist/antagonist, or antagonist.

Pure opioid agonists (e.g., morphine, hydromorphone, fentanyl) stimulate mu receptors and are the most potent analgesics. As the dose is increased, analgesia occurs in a log linear fashion; the degree of analgesia induced is limited only by intolerable doserelated adverse effects. Partial agonists and agonist/ antagonists (example, nalorphine) exhibit a ceiling effect on the degree of analgesia that they can produce. Antagonists, as the name implies, counteracts effects at the opioid receptor.

\subsubsection{Opioid Categories}

The DEA classifies opioids into schedules related to potential abuse, and not potency (Table 10).

There has been concern that the lower scheduled opioids (Schedule III and IV) might have a higher addictive potential than some of the higher scheduled opioids (Schedule II). In a recent study (236), it was suggested that shorter-acting opioids had a lower potential for abuse. They looked at 140 patients on longacting opioids (Schedule II) compared to 687 patients on short-acting opioids and 225 patients on nonopioids. More of the long-acting opioid patients (38\%) were discharged from the practice for non-compliance compared to the short-acting opioid patients (32\%) or the nonopioid patients (30\%). In another study (161) in an interventional pain management setting evaluating the abuse of prescription and illicit drugs in chronic pain patients receiving either short-acting (hydrocodone) or long-acting (methadone), they concluded that prescription drug abuse as well as illicit drug use was similar in both groups of patients.

\subsubsection{Opioid Metabolism}

Many of the side effects of opioids, as well as their effects, may be related to the opioid metabolites. Most of the metabolism of opioids occurs in the liver. The CYP450 enzymes are a super-family of heme-containing, microsomal drug-metabolizing enzymes that are important in the biosynthesis and degradation of a wide variety of endogenous compounds, chemicals, toxins, and medications. More than 2,700 individual members of the CYP450 super-family have been identified, and 57 cytochrome P450 enzymes are recognized in humans (237). CYP3A4 is the isoenzyme most frequently involved in drug metabolism, and accounts 
Table 9. Illustration of activity of opioid receptors.

\begin{tabular}{|c|c|c|c|}
\hline & Mu $(\mu)$ & $\operatorname{Delta}(\Delta)$ & Kappa (к) \\
\hline & $\begin{array}{l}\bullet \text { Mu } 1 \text { - Analgesia } \\
\text { • Mu } 2 \text { - Sedation, vomiting, } \\
\text { respiratory depression, pruritus, } \\
\text { euphoria, anorexia, urinary retention, } \\
\text { physical dependence }\end{array}$ & - Analgesia, spinal analgesia & $\begin{array}{l}\text { - Analgesia, sedation, dyspnea, } \\
\text { psychomimetic effects, miosis, } \\
\text { respiratory depression, euphoria, } \\
\text { dysphoria, dyspnea }\end{array}$ \\
\hline \multicolumn{4}{|l|}{ Endogenous Peptides } \\
\hline Enkephalins & Agonist & Agonist & \\
\hline$\beta$-Endorphin & Agonist & Agonist & \\
\hline Dynorphin A & Agonist & & Agonist \\
\hline \multicolumn{4}{|l|}{ Agonists } \\
\hline Morphine & Agonist & & Weak agonist \\
\hline Codeine & Weak agonist & Weak agonist & \\
\hline Fentanyl, sufentanil, & Agonist & & \\
\hline Meperidine & Agonist & Agonist & \\
\hline Methadone & Agonist & & \\
\hline \multicolumn{4}{|l|}{ Agonist-antagonists } \\
\hline Nalorphine & Antagonist & & Agonist \\
\hline \multicolumn{4}{|l|}{ Antagonists } \\
\hline Naloxone & Antagonist & Weak Antagonist & Antagonist \\
\hline Naltrexone & Antagonist & Weak Antagonist & Antagonist \\
\hline
\end{tabular}

Table 10. DEA schedules of controlled drugs.

\begin{tabular}{|c|l|l||}
\hline \hline Schedule & Criteria & Examples \\
\hline I & No medical use; high addiction potential & Heroin, marijuana, PCP \\
\hline II & Medical use; high addiction potential & Morphine, oxycodone, methadone, fentanyl, amphetamines \\
\hline III & Medical use; moderate addiction potential & Hydrocodone, codeine, anabolic steroids \\
\hline IV & Medical use; low abuse potential & Benzodiazepines, meprobamate, butorphanol, pentazocine, propoxyphene \\
\hline V & Medical use; low abuse potential & Buprenex, phenergan with codeine \\
\hline \hline
\end{tabular}

for approximately $50 \%$ of marketed drug metabolism, and levels of CYP3A4 may vary as much as 30-fold between individuals (238), leading to large variability in blood levels. The metabolism of more than $90 \%$ of the most clinically important medications can be accounted for by 7 CYP isozymes (3A4, 3A5, 1A2, 2C9, 2C19, 2D6, and 2E1) (239). CYP1A2, CYP2C8, and CYP2C9 make up about $10 \%$ of the enzymes, CYP2D6 and CYP2E1 each around 5\%, and CYP2C19 around $1 \%$. CYP2D6 is entirely absent in some populations; for example, 6-10\% of Caucasians are 2D6 deficient (240), while other persons have high levels of this enzyme, leading to rapid metabolism of the medicines.

\subsection{Adverse Effects}

Complications due to opioid administration concern all medical practitioners $(7,8)$. Commonly known side effects of opioids include constipation, pruritus, respiratory depression, nausea, vomiting, delayed gastric emptying, sexual dysfunction, muscle rigidity and myoclonus (may be present in 3 to $87 \%$ of cancer patients, may be mediated by glycine inhibition in the dorsal horn neurons, and may be treated by opioid reduction or rotation, as well as benzodiazepines and baclofen) $(241,242)$, sleep disturbance (243) (morphine has been shown to reduce REM sleep via inhibition of acetylcholine release in the reticular activating formation (244), pyrexia, diminished 
psychomotor performance (which appears to be more of a problem with acute rather than chronic use) (245), cognitive impairment (246), dizziness and sedation, all reflecting the effects of opioids at multiple organ systems (247). Psychostimulants may improve psychomotor performance scores and subjective drowsiness (248). An imbalance in the cholinergic/dopaminergic CNS system is felt to be the mechanism of opioid-induced delirium (244). Hyperalgesia is a gradual increase in neural response to repeated stimulation (249).

Adverse events, in general, appear to fall into 2 broad categories: non-life threatening and life threatening. Hydrocodone may cause sensorineural hearing loss due to possible genetic polymorphisms. More serious adverse events such as respiratory depression and death have been seen with the use of fentanyl buccal tablets for breakthrough pain. Drug deaths from opioids are a serious and increasing issue. Strong patient compliance with medical treatment programs is needed to prevent rare but life-threatening adverse events.

\subsection{Drug Interactions}

A drug interaction occurs when the amount or the action of a drug is altered by the administration of another drug or multiple drugs. Multiple hepatic drug interactions may influence opioid drug levels $(8,231,232)$ as illustrated in Table 11.

\subsection{Drug Conversions}

While there have been multiple opioid conversion charts developed, none are reliable and none take into consideration the vast individual differences in effect and metabolism between patients and within medications. Brand name and generic medications may have significant differences in bioavailability, and metabolism of medications may be influenced by genetic polymorphism and dug interactions. It is therefore important to recognize that "equipotent" doses of medications may have very different degrees of analgesia and side effects. In general, to switch between medications, the clinician must calculate a rough equiva-

Table 11. Drug interactions of opioids.

\begin{tabular}{|c|c|}
\hline Tricyclic antidepressants & $\begin{array}{l}\text { Inhibit morphine glucuronidation leading to } \Uparrow \text { blood levels } \\
\text {--- Nortriptyline inhibits noncompetitively } \\
\text {--- Amitriptyline and clomipramine inhibit competitively }\end{array}$ \\
\hline Methadone and morphine & $\Downarrow$ metabolism of TCAs, leading to toxicity \\
\hline Quinine & $\Downarrow$ conversion of codeine to morphine leading to $\bigotimes$ analgesia \\
\hline Metoclopramide & Earlier peak plasma levels with controlled-released opioids \\
\hline Meperidine & MAO inhibitors trigger hyperpyrexia \\
\hline Propoxyphene & $\begin{array}{l}\Uparrow \text { carbamazepine, doxepin, metoprolol, propranolol levels } \\
\Downarrow \text { excretion of benzodiazepines, leading to accumulation and overdose }\end{array}$ \\
\hline Erythromycin & $\Uparrow$ opioid effects \\
\hline Venlafaxine & $\Uparrow$ methadone levels \\
\hline $\begin{array}{l}\text { Rifampin } \\
\text { Phenytoin } \\
\text { Carbamazepine }\end{array}$ & $\Downarrow$ methadone levels \\
\hline $\begin{array}{l}\text { Phenytoin } \\
\text { Phenobarbital }\end{array}$ & $\Downarrow$ meperidine levels \\
\hline CY2D6 inhibitors & $\begin{array}{l}\Uparrow \text { tramadol levels } \\
\Downarrow \text { analgesia from hydrocodone/codeine }\end{array}$ \\
\hline CY2D6 substrates & $\Uparrow$ tramadol levels because of competition for metabolism \\
\hline CYP3A4 inhibitors & $\Uparrow$ methadone levels \\
\hline CYP3A4 inducers & $\Downarrow$ methadone levels \\
\hline Methadone and morphine & $\Downarrow$ metabolism of desipramine, leading to toxicity \\
\hline
\end{tabular}


lent 24-hour dose, divide by the dosing schedule, and then "under-dose," especially with methadone, with subsequent titration to effect.

\subsection{Opioid Therapy and Side Effects}

Multiple reviews $(231-235,250)$ described opioid pharmacology of agonists, antagonists, partial agonists, agonists and antagonists, peripherally-acting opioids, combination opioid analgesics, and variations in opioid responsiveness. Implications and side effects of long-term opioid therapy include opioid-induced immunologic effects, hormonal changes, hyperalgesia, sedation, sleep disturbances, psychomotor disturbances, constipation, bladder dysfunction, and cardiac effects (8). Opioid complications and side effects in detail along with appropriate management of these side effects were described (8).

\subsection{Terminology of Abuse and Adpiction}

\subsection{Introduction}

The terminology related to abuse and addiction of opioids and other controlled substances is considered confusing and reflects lack of understanding of multiple issues related to abuse and addiction. There are 3 fundamental concepts related to addiction:

1) the determination of addiction rests with the user even though some drugs produce pleasurable reward:

2) addiction is a multidimensional disease with neurobiological and psychosocial dimensions: and

3) addiction is a phenomenon distinct from physical dependence and tolerance.

Addiction is related to the "reward center" located within the mesocorticolimbic dopamine systems in the brain (251). Up-regulation of cAMP pathways in the brain (locus coeruleus) and spinal cord leads to acute physical withdrawal symptoms when the administered opioid is reduced or stopped, resulting in excessive central norepinephrine release, and its manifestations (252). Addiction is therefore a physiologic response, influenced by a variety of psychosocial issues (such as depression and anxiety) as well as genetic issues (family history of addiction).

\subsection{History}

More than a century ago, the debate over how best to address the misuse and abuse of prescription medications began, at a time when the most com- monly abused drugs were freely available (253). As an example, heroin (diacetyl morphine) was developed to help morphine addicts; "heroin was sold over the counter as a soothing syrup for colicky babies and cocaine was the reason a then-new beverage invented in an Atlanta pharmacy was called 'Coke' (254)."

\subsection{Terminology}

Despite significant growth in understanding of the scientific basis of addiction, definitions and diagnostic criteria based on obsolete conceptualization of addiction persist. The following terms have been defined by World Health Organization (WHO), DSM-IV, and United States Federal and State policies, and other organizations by means of consensus statements.

There continues to be confusion and misunderstanding concerning the term "addiction." The Controlled Substance Act defined addiction as a term meaning any individual who habitually uses any narcotic drug so as to endanger the public morals, health, safety, or welfare or who is so far addicted to the use of narcotic drugs as to have lost the power of self-control with reference to his or her addiction (255).

\subsubsection{Substance Abuse}

DSM-IV defines substance abuse as a maladaptive pattern of substance use leading to significant impairment or distress in the last 12 months with one (or more) events such as failure to fulfill major role obligations, using inappropriate substances, participating in hazardous situations, being involved in recurrent substance related legal problems, and/or continuing use in the face of adverse consequences.

\subsubsection{Substance Dependence}

DSM-IV defines substance dependence as a maladaptive pattern of substance use leading to significant impairment or distress in the last 12 months meeting the criteria for substance abuse plus 3 or more of the following 7 criteria during the same 12-month period: tolerance, withdrawal, inability to control use, unsuccessful attempts to decrease or discontinue use, a great deal of time lost in obtaining the substance, using the substance, or recovering from its effects, important activities are given up because of use, continued use despite physical or psychological problems caused by use, and continued use of a substance.

\subsubsection{Tolerance}

The need for an increased dosage of a drug to produce the same level of analgesia that previously existed is defined as tolerance. Tolerance also suspect- 


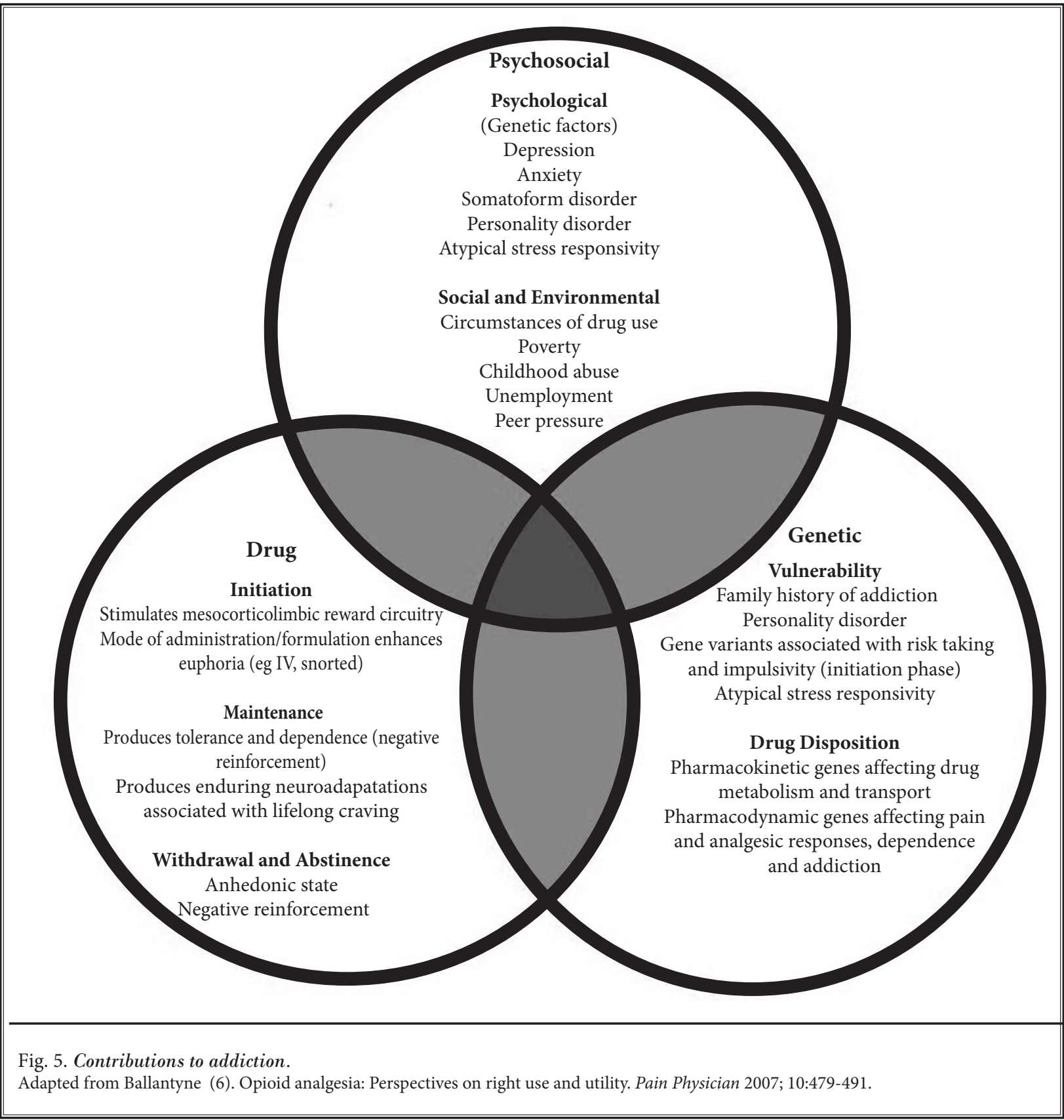

ed when a reduced physiologic effect is observed with constant dosing. Analgesic tolerance is not always evident during opioid treatment, and is not to be confused with addiction, which occurs as a dysfunctional craving of a drug action by physiologic action and psychologically driven factors.

\subsubsection{Withdrawal}

Withdrawal describes a characteristic set of symp- toms that occur when a substance is withdrawn, and those symptoms disappear when the substance is reintroduced.

\subsubsection{Physical Dependence}

Physical dependence is a state of adaptation that is manifested by a drug class specific withdrawal syndrome that can be produced by a drug cessation, rapid dose reduction, decreasing blood level of the 
drug, and/or administration of an antagonist. Physical dependence is a normal adaptation to the drug, reinforced by continued use. Physical dependence is most commonly associated with withdrawal symptoms when the substance is abruptly discontinued, and is seen in many classes of medication not associated with addiction, such as beta blockers.

\subsubsection{Addiction}

In contrast to tolerance, withdrawal, and physical dependence, addiction is compulsive use of a drug despite physical harm, and the terms tolerance and addiction are not interchangeable. The terminology may share similar characteristics, as many addicts do become tolerant of their chosen drug, which can be expected with regular use. Addiction is a dysfunctional use behavior that includes one or more of the following: impaired control over drug use, compulsive use, continued use despite harm and craving, while tolerance is a physiologic alteration of metabolism.

In a chronic pain state, a patient may be exposed to a controlled substance for a prolonged period of time, developing tolerance and physical dependence. Addiction may occur, but is an unlikely event. Dependence does not foreshadow harm, or intent at self-destructive behavior. It is therefore, incumbent upon the pain management physician to determine that these definitions and their physiologic undertones are well understood, and that the overlap of these definitions does not necessarily define a controlled substance risk or an inappropriate patient. In other words, tolerance and dependence share many common physiologic characteristics, and addiction may be associated with, but not defined by, either or both. Physical dependence, addiction, and tolerance are physiologic, social, and psychological considerations with prolonged substance management.

\subsection{Opioid Agonist Therapy}

Opioid agonist therapy (OAT) is a term used when a prescribed drug is given to occupy the receptor sites that otherwise would respond to an illicit agent such as heroin (229). OAT is a widely accepted medical treatment for opioid addiction, with efficacy that has been documented in many studies over many years (256). The best-known and most widely used form of OAT involves methadone maintenance treatment (MMT), though a second and newer form of OAT employs buprenorphine (a partial agonist), which is able to block the effects of morphine and other opioids, while offering mild opioid-like effects $(232,257)$.

\subsection{Clinical Effectiveness}

\subsection{Introduction}

Considerable controversy over the prescription of opioids for chronic non-cancer pain continues despite the growing acceptance of this practice and claims that pain is undertreated. WHO developed a step-ladder approach to the management of pain. It recommends nonopioid analgesics initially, and then suggests the addition of mild opioids (e.g., hydrocodone) for mild to moderate pain, reserving strong opioids such as morphine for severe pain (258). In addition, opioids have been endorsed by multiple societies and advocacy organizations as appropriate treatment for refractory chronic non-cancer pain in the general population, when used judiciously and according to guidelines similar to those used for cancer patients. The DEA has also taken the position that clinicians should be knowledgeable about using opioids to treat pain, and should not hesitate to prescribe them when opioids are the best clinical choice of treatment (255). However, these endorsements of opioids in chronic noncancer pain vary widely based on the philosophy of organizations, advocacy, ethical, and financial interests. Variations are evident with regards to the selection criteria, documentation, drug dosages, frequency, duration, and break through pain management. While all agree that opioids are indicated in cancer pain, numerous questions continue to arise about opioid usage in non-cancer pain on a long-term basis. Consequently, there is wide disagreement on who should be treated, how much should be provided, and who should be monitoring the controlled substances, their abuse, diversion, and side effects.

The clinical effectiveness of opioid medications for non-cancer pain in humans is difficult to measure. Since the publication of the ASIPP Opioid Guidelines by Trescot et al (1) in 2006, several new studies, including systematic reviews, observational studies, and controlled trials, evaluated the clinical effectiveness of medications.

\subsection{Systematic Reviews}

As illustrated in Table 3 and Fig. 1, from 1997 to 2006 the use of methadone increased exponentially followed by oxycodone, fentanyl base, hydromorphone, hydrocodone, morphine, and codeine. However, the highest use of per milligram per person in the United States for 2006 was methadone followed by oxycodone, fentanyl, hydrocodone, and morphine (Table 4). 
Further, the proportion of the highest use of opioids is oxycodone, followed by hydrocodone, whereas the highest growth is in methadone with an increase of 1,129\% from 1997 to 2006 (Table 4) (5).

The available evidence is highly variable. There is literature support for long-term use of opioids in chronic non-cancer pain with improvement in function and reduction in pain for longer than 6 months for transdermal fentanyl and sustained-release morphine (albeit weak) $(9,19)$. However, the evidence is limited for the most commonly used opioid, i.e., oxycodone, in the United States. Further, for the second most commonly used opioid in the United States, hydrocodone, the evidence is non-existent. The evidence for methadone and other drugs is also non-existent. This lack of evidence for the most commonly used opioids and weak evidence for morphine and transdermal fentan$\mathrm{yl}$ are insurmountable factors in the synthesis of evidence-based guidelines for opioid use for long-term management of chronic non-cancer pain.

Noble et al (9) in a systematic review and metaanalysis of efficacy and safety of long-term opioid therapy for chronic non-cancer pain, published in 2008, reviewed the clinical evidence on patients treated with opioids for chronic non-cancer pain for at least 6 months. They identified 115 studies from 11 databases until April 7, 2007. Of these, 17 studies met the inclusion criteria. Seven studies of 1,504 patients evaluated oral opioids (259-265), whereas 3 studies with 1,993 patients $(259,266,267)$ evaluated transdermal opioids. Table 12 illustrates characteristics of the included studies in the evaluation of long-term ef-

Table 12. Characteristics of included studies in evaluation of the long-term effectiveness by Noble et al (9).

\begin{tabular}{|c|c|c|c|c|c|c|c|}
\hline \multirow{3}{*}{ Reference } & \multirow{3}{*}{ Opioid } & \multirow{3}{*}{$\begin{array}{c}\text { Type of } \\
\text { Predominant } \\
\text { Pain }\end{array}$} & \multirow{3}{*}{$\begin{array}{c}\text { Number } \\
\text { of } \\
\text { Patients } \\
\text { Enrolled }\end{array}$} & \multicolumn{4}{|c|}{ Outcomes Used in Evidence Synthesis } \\
\hline & & & & \multirow{2}{*}{$\begin{array}{c}\text { Withdrawal } \\
\text { Due to } \\
\text { Adverse } \\
\text { Events }\end{array}$} & \multirow{2}{*}{$\begin{array}{l}\text { Withdrawal } \\
\text { Due to } \\
\text { Insufficient } \\
\text { Pain Relief }\end{array}$} & \multicolumn{2}{|c|}{ Pain } \\
\hline & & & & & & $\begin{array}{l}\text { Continuous/ } \\
\text { Categorical }\end{array}$ & $\begin{array}{l}>\mathbf{5 0} \% \\
\text { Relief }\end{array}$ \\
\hline \multicolumn{8}{|c|}{ Oral Administration } \\
\hline Allan et al (259) & Morphinea & Low back pain & 342 & $\checkmark$ & $\checkmark$ & $\mathrm{b}$ & $\checkmark$ \\
\hline $\begin{array}{l}\text { Caldwell et al } \\
\text { (260) }\end{array}$ & Morphinea & Osteoarthritis & $(295)^{c} 181$ & $\checkmark$ & $\checkmark$ & $\mathrm{d}$ & \\
\hline Harati et al (261) & Tramadol & $\begin{array}{c}\text { Diabetic } \\
\text { neuropathy }\end{array}$ & $(131)^{c} 117$ & $\checkmark$ & $\checkmark$ & $\checkmark$ & \\
\hline $\begin{array}{l}\text { Fredheim et al } \\
\text { (262) }\end{array}$ & Methadone & Low back pain & 12 & $\checkmark$ & $\checkmark$ & e & \\
\hline $\begin{array}{l}\text { Mcllwain and } \\
\text { Ahdieh (263) }\end{array}$ & $\begin{array}{c}\text { Extended-release } \\
\text { oxymorphone }\end{array}$ & Osteoarthritis & $(491)^{c} 153$ & $\checkmark$ & $\checkmark$ & $\checkmark$ & \\
\hline Roth et al (264) & $\begin{array}{c}\text { Controlled-release } \\
\text { oxycodone }\end{array}$ & Osteoarthritis & $(133)^{c} 106$ & $\checkmark$ & $\checkmark$ & $\checkmark$ & \\
\hline Zenz et al (265) & $\begin{array}{c}\text { Dihydrocodeine, a } \\
\text { buprenorphine, or } \\
\text { morphinea }\end{array}$ & $\begin{array}{c}\text { Neuropathic or } \\
\text { back pain }\end{array}$ & 100 & & $\checkmark$ & & $\checkmark$ \\
\hline \multicolumn{8}{|c|}{ Transdermal Administration } \\
\hline Allan et al (259) & Fentanyl & Low back pain & 338 & $\checkmark$ & $\checkmark$ & $\mathrm{b}$ & \\
\hline $\begin{array}{c}\text { Milligan et al } \\
(266)\end{array}$ & Fentanyl & Unspecified & 532 & $\checkmark$ & $\checkmark$ & $\mathrm{f}$ & \\
\hline $\begin{array}{c}\text { Mystakidou et al } \\
\text { (267) }\end{array}$ & Fentanyl & Unspecified & 529 & $\checkmark$ & $\checkmark$ & $\checkmark$ & \\
\hline
\end{tabular}

a Sustained release.

b Not analyzed because of number of patients at follow-up times not reported.

c N in parentheses denotes number of patients randomized in original RCT; second number is that enrolled in open-label extension.

$\mathrm{d}$ Not meta-analyzed because reported units are statistically incompatible with the 3 other studies meeting inclusion criteria.

e Not analyzed because data were reported for fewer than 10 patients at follow-up times.

$\mathrm{f}$ Not analyzed because instrument used not validated.

Adapted and modified from Noble et al (9). Long-term opioid therapy for chronic noncancer pain: A systematic review and meta-analysis of efficacy and safety. J Pain Symptom Manage 2008; 35:214-228. 
fectiveness of morphine and transdermal fentanyl by Noble et al (9). Trescot et al (19) evaluated specifically the role long-term opioid therapy.
Tables 13 and 14 illustrate effectiveness of longterm sustained-release morphine and transdermal fentanyl. They concluded that sustained-released morphine and transdermal fentanyl provided weak

Table 13. Results of studies evaluating the long-term effectiveness of morphine.

\begin{tabular}{|c|c|c|c|c|c|c|}
\hline Study/ methods & Participants & Opioids studied & Outcome(s) & Result(s) & Conclusion(s) & Complications \\
\hline $\begin{array}{l}\text { Allan et al (259) } \\
\text { Open, randomized, } \\
\text { parallel group } \\
\text { multicenter study } \\
13 \text { months }\end{array}$ & $\begin{array}{l}\text { Chronic low } \\
\text { back pain } \\
N=680\end{array}$ & $\begin{array}{l}\text { Sustained release } \\
\text { oral morphine } \\
\text { versus transdermal } \\
\text { fentanyl }\end{array}$ & $\begin{array}{l}\text { Pain relief; bowel } \\
\text { function, quality } \\
\text { of life, disease } \\
\text { progression, and } \\
\text { side effects }\end{array}$ & $\begin{array}{l}\text { Significant } \\
\text { proportion of } \\
\text { patients on } \\
\text { sustained release } \\
\text { morphine } \\
\text { experienced pain } \\
\text { relief }\end{array}$ & $\begin{array}{l}\text { Sustained release } \\
\text { strong opioids } \\
\text { can safely be used } \\
\text { in opioid naïve } \\
\text { patients }\end{array}$ & $\begin{array}{l}\text { Most common } \\
\text { adverse events } \\
\text { leading to } \\
\text { discontinuation } \\
\text { were nausea ( } 37 \%) \text {, } \\
\text { vomiting and } \\
\text { constipation. }\end{array}$ \\
\hline $\begin{array}{l}\text { Caldwell et al (260) } \\
\text { Double-blind trial, } \\
\text { followed by open- } \\
\text { label extension trial }\end{array}$ & $\begin{array}{l}\begin{array}{l}184 \text { with } \\
\text { chronic } \\
\text { osteoarthritis }\end{array} \\
181 \text { patients } \\
\text { entered the } \\
\text { open-label } \\
\text { trial }\end{array}$ & $\begin{array}{l}\text { Placebo, Avinza, } \\
\text { or MS Contin in } \\
\text { double-blind trial }\end{array}$ & $\begin{array}{l}\text { Pain relief; } \\
\text { physical } \\
\text { functioning; } \\
\text { stiffness }\end{array}$ & $\begin{array}{l}\text { Significant } \\
\text { improvement in } \\
\text { pain relief and } \\
\text { sleep measures }\end{array}$ & $\begin{array}{l}\text { Efficacy was } \\
\text { comparable } \\
\text { between two modes } \\
\text { of administration. }\end{array}$ & $\begin{array}{l}\text { Most common } \\
\text { adverse effects were } \\
\text { constipation and } \\
\text { nausea }\end{array}$ \\
\hline $\begin{array}{l}\text { Zenz et al (265) } \\
\text { Narrative descriptive } \\
\text { report }\end{array}$ & $\begin{array}{l}100 \text { patients } \\
\text { who were } \\
\text { chronically } \\
\text { given } \\
\text { opioids for } \\
\text { treatment of } \\
\text { nonmalignant } \\
\text { pain, with } \\
23 \text { patients } \\
\text { receiving } \\
\text { morphine SR }\end{array}$ & $\begin{array}{l}\text { Sustained release } \\
\text { morphine, } \\
\text { sustained release } \\
\text { dihydrocodeine, } \\
\text { buprenorphine }\end{array}$ & $\begin{array}{l}\text { VAS, Karnofsky } \\
\text { Performance } \\
\text { Status Scale } \\
\text { used to assess } \\
\text { function }\end{array}$ & $\begin{array}{l}\text { Good pain relief } \\
\text { was obtained in } \\
51 \text { patients and } \\
\text { partial pain relief } \\
\text { was reported by } \\
28 \text { patients. Only } \\
21 \text { patients had } \\
\text { no beneficial } \\
\text { effect from } \\
\text { opioid therapy }\end{array}$ & $\begin{array}{l}\text { Results indicate } \\
\text { that opioids can be } \\
\text { effective in chronic } \\
\text { nonmalignant pain, } \\
\text { with side effects } \\
\text { that are comparable } \\
\text { to those that } \\
\text { complicate the } \\
\text { treatment of cancer } \\
\text { pain }\end{array}$ & $\begin{array}{l}\text { Common side } \\
\text { effects were } \\
\text { constipation and } \\
\text { nausea }\end{array}$ \\
\hline $\begin{array}{l}\text { Maier et al (296) } \\
\text { Narrative descriptive } \\
\text { report }\end{array}$ & $\begin{array}{l}121 \text { patients } \\
\text { with chronic } \\
\text { non-cancer } \\
\text { pain }\end{array}$ & $\begin{array}{l}\text { Sustained release } \\
\text { morphine }\end{array}$ & $\begin{array}{l}\text { Pain relief and } \\
\text { quality of life }\end{array}$ & $\begin{array}{l}\text { Significantly } \\
\text { lower pain } \\
\text { intensity and } \\
\text { improved } \\
\text { physical state } \\
\text { and quality of life }\end{array}$ & $\begin{array}{l}\text { Pain relief } \\
\text { correlated with } \\
\text { improvement in } \\
\text { functional status }\end{array}$ & $\begin{array}{l}\text { There was no } \\
\text { development of } \\
\text { tolerance }\end{array}$ \\
\hline $\begin{array}{l}\text { Tassain et al (297) } \\
\text { Long-term } \\
\text { prospective study }\end{array}$ & $\begin{array}{l}28 \text { chronic } \\
\text { non-cancer } \\
\text { pain patients, } \\
18 \text { received } \\
\text { oral sustained } \\
\text { morphine, } \\
10 \text { patients } \\
\text { stopped } \\
\text { morphine due } \\
\text { to side effects } \\
\text { and were } \\
\text { followed as } \\
\text { control group }\end{array}$ & $\begin{array}{l}\text { Oral sustained } \\
\text { morphine }\end{array}$ & $\begin{array}{l}\text { Pain relief } \\
\text { and cognitive } \\
\text { functioning } \\
\text { Follow-up period } \\
\text { of } 12 \text { months }\end{array}$ & $\begin{array}{l}\text { Morphine } \\
\text { produced } \\
\text { persistent } \\
\text { pain relief and } \\
\text { improved quality } \\
\text { of life and mood }\end{array}$ & $\begin{array}{l}\text { There was no } \\
\text { impairment of any } \\
\text { neuropsychological } \\
\text { variables over time }\end{array}$ & $\begin{array}{l}\text { Side effects } \\
\text { included } \\
\text { constipation, } \\
\text { loss of appetite, } \\
\text { nausea, dry mouth, } \\
\text { drowsiness, } \\
\text { somnolence, } \\
\text { fatigue, subjective } \\
\text { memory } \\
\text { impairment, } \\
\text { sweating, and } \\
\text { pruritus }\end{array}$ \\
\hline
\end{tabular}

Adapted from Trescot et al (19). Effectiveness of opioids in the treatment of chronic non-cancer pain. Pain Physician 2008; 11:S181-S200. 
Table 14. Results of studies evaluating long-term effectiveness of transdermal fentanyl.

\begin{tabular}{|c|c|c|c|c|c|c|}
\hline Study/ methods & Participants & Opioids studied & Outcome(s) & Result(s) & Conclusion(s) & Complications \\
\hline $\begin{array}{l}\text { Allan et al (259) } \\
\text { Open, } \\
\text { randomized, } \\
\text { parallel group } \\
\text { multicenter } \\
\text { study } \\
13 \text { months }\end{array}$ & $\begin{array}{l}338 \text { patients } \\
\text { were } \\
\text { studied with } \\
\text { transdermal } \\
\text { fentanyl with } \\
\text { chronic low } \\
\text { back pain }\end{array}$ & $\begin{array}{l}\text { Evaluation of } \\
\text { transdermal } \\
\text { fentanyl in } \\
\text { strong-opioid } \\
\text { naïve patients } \\
\text { with chronic low } \\
\text { back pain }\end{array}$ & $\begin{array}{l}\text { Pain relief, } \\
\text { bowel } \\
\text { function, } \\
\text { quality of } \\
\text { life, disease } \\
\text { progression, } \\
\text { and side } \\
\text { effects }\end{array}$ & $\begin{array}{l}\text { Transdermal } \\
\text { fentanyl provided } \\
\text { significant pain } \\
\text { relief }\end{array}$ & $\begin{array}{l}\text { Transdermal } \\
\text { fentanyl can } \\
\text { safely be used } \\
\text { in opioid naïve } \\
\text { patients }\end{array}$ & $\begin{array}{l}\text { Most common } \\
\text { side effects } \\
\text { included } \\
\text { constipation, } \\
\text { nausea, and } \\
\text { vomiting }\end{array}$ \\
\hline $\begin{array}{l}\text { Milligan et al } \\
\text { (266) } \\
\text { International, } \\
\text { multicenter, } \\
\text { open label trial }\end{array}$ & $\begin{array}{l}532 \text { pts w/ } \\
\text { chronic non- } \\
\text { cancer pain } \\
\text { studied over } \\
12 \text { months } \\
51 \% \\
\text { completed } \\
\text { trial. } 25 \% \\
\text { withdrew } \\
\text { because of } \\
\text { adverse events }\end{array}$ & $\begin{array}{l}\text { Transdermal } \\
\text { fentanyl } \\
\text { compared } \\
\text { to previous } \\
\text { medication (over } \\
40 \text { different } \\
\text { opioids) }\end{array}$ & $\begin{array}{l}\text { Preference of } \\
\text { medication, } \\
\text { pain control, } \\
\text { SF-36, global } \\
\text { satisfaction, } \\
\text { requirement } \\
\text { for break- } \\
\text { through pain }\end{array}$ & $\begin{array}{l}67 \% \text { rated pain } \\
\text { relief as very } \\
\text { good to moderate } \\
\text { on transdermal } \\
\text { fentanyl, } 86 \% \\
\text { preferred } \\
\text { transdermal } \\
\text { fentanyl, SF- } \\
36 \text { showed } \\
\text { improvement for } \\
\text { body pain only }\end{array}$ & $\begin{array}{l}\text { Long-term } \\
\text { treatment with } \\
\text { transdermal } \\
\text { fentanyl offered } \\
\text { majority of } \\
\text { patients at least } \\
\text { moderate relief }\end{array}$ & $\begin{array}{l}\text { Nausea 31\%; } \\
\text { constipation } \\
19 \% ; \\
\text { somnolence } \\
18 \% ; \\
\text { respiratory } \\
\text { depression, } \\
\text { abuse, or } \\
\text { less } 1 \% \text {; } \\
\text { withdrawal } 3 \%\end{array}$ \\
\hline $\begin{array}{l}\text { Mystakidou et } \\
\text { al (267) } \\
\text { Prospective } \\
\text { open-label study }\end{array}$ & $\begin{array}{l}529 \text { patients } \\
\text { being treated } \\
\text { with oral } \\
\text { codeine or oral } \\
\text { morphine }\end{array}$ & $\begin{array}{l}\text { Transdermal } \\
\text { therapeutic } \\
\text { system fentanyl }\end{array}$ & $\begin{array}{l}\text { Quality of } \\
\text { Life-Short } \\
\text { Form } 12\end{array}$ & $\begin{array}{l}\text { Transdermal } \\
\text { therapeutic } \\
\text { system-fentanyl } \\
\text { significantly } \\
\text { improves quality } \\
\text { of life within } 28 \\
\text { days, and pain } \\
\text { management } \\
\text { within } 48 \text { hours }\end{array}$ & $\begin{array}{l}\text { Transdermal } \\
\text { therapeutic } \\
\text { system-fentanyl } \\
\text { is a safe and } \\
\text { effective pain } \\
\text { management }\end{array}$ & $\begin{array}{l}\text { Side effects, } \\
\text { with } \\
\text { constipation } \\
\text { (range } 4.6 \% \text { - } \\
23.1 \% \text { ) and } \\
\text { nausea were } \\
\text { the most } \\
\text { frequent }\end{array}$ \\
\hline
\end{tabular}

Adapted from Trescot et al (19). Effectiveness of opioids in the treatment of chronic non-cancer pain. Pain Physician 2008; 11:S181-S200.

evidence for improvement in physical status and decrease in pain on a long-term basis, whereas, tramadol provided weak evidence in osteoarthritis patients. However, the most commonly used, oxycodone, provided only limited evidence, while, the second most commonly used, hydrocodone, had no published evidence. Similarly, other commonly used opioids had no published evidence of effectiveness with long-term therapy.

Overall, many patients withdrew from the clinical trials due to adverse effects with $32.5 \%$ with oral therapy and $17.5 \%$ with transdermal therapy; $11.9 \%$ in the oral therapy group and $5.8 \%$ in the transdermal group withdrew due to insufficient pain relief. They concluded that there was an insufficient amount of data on transdermal opioids to quantify pain relief. For patients able to maintain on oral or intrathecal opioids for at least 6 months, pain scores were reduced long-term with a $38 \%$ mean reduction in pain scores in the intrathecal group and $63.4 \%$ mean reduction in pain scores in oral opioid group when treatment lasted 6-18 months. However, there was substantial heterogenicity in the oral studies, which could not be resolved using meta-regression by follow-up time. Further, the summary effect estimate of pain relief from oral opiates was not robust to sensitivity analysis. Consequently, due to lack of robustness upon sensitivity analysis and unexplained heterogenicity, the quantitative estimates of the amount of pain relief associated with opioid therapy may be unstable. Even then, 
long-term opioids were associated with some degree of pain relief. Many patients in the included studies were so dissatisfied with adverse events or insufficient pain relief from opioids that they withdrew from the studies. Even then, for patients able to continue on opioids, evidence (albeit weak) suggested that their pain scores were lower than before therapy began and that this relief would be maintained long-term over 6 months. The data describing long-term safety and efficacy of opioids was insufficient, providing only weak evidence. The evaluations shown for oral opioids (259265) studied the effectiveness of morphine in 2 studies $(259,260)$, tramadol in one study $(261)$, methadone in one study (262), extended-release oxymorphone in one study (263), controlled-release oxycodone in one study (264), and dihydrocodeine, buprenorphine and morphine in one study (265). Thus, overall morphine was studied in 2 studies and all others in one; however, hydrocodone was not studied. Transdermal studies included only fentanyl $(259,266,267)$.

The first systematic review of comparative efficacy and safety of long-acting oral opioids for chronic non-cancer pain was published by Chou et al (11), the Oregon Health Resources Commission (OHRC). A total of 16 randomized trials evaluating comparative efficacy and adverse events, enrolling 1,427 patients, and 8 observational studies of adverse events of 1,190 patients were included in this review through October 2002. They were unable to rate any randomized trial as good quality, whereas observational studies were generally of poorer quality than randomized trials. They concluded that there was insufficient evidence to prove that different long-acting opioids are associated with different efficacy or safety profiles. Further, there was also insufficient evidence to determine whether long-acting as a class are more effective or safer than short-acting opioids. They found a subgroup of 3 studies on long-acting versus short-acting oxycodone was more homogenous and provided fair evidence that these formulations were equally effective for pain control (268-270). They included studies with evaluation for as early as 6 days and the longest in randomized trials was 16 weeks. In this study, 2 of the 16 trials compared one long-acting opioid to another one $(260,271)$, one of the trials $(271)$ compared transdermal fentanyl to long-acting morphine, whereas the second trial (260) compared a once daily morphine preparation to a twice daily morphine preparation. Seven trials compared a long-acting opioid to a short-acting opioid (268-270,272-275), and 7 com- pared a long-acting opioid to a nonopioid or placebo (264,276-281). They identified trials on long-acting oxycodone (264,268-270,281), long-acting morphine $(260,271,274,277-279)$, long-acting dihydrocodeine $(273,275)$, long-acting codeine $(272,276,280)$, and transdermal fentanyl (271). The authors did not identify any trials on methadone, levorphanol, and hydrocodone. The average of enrollment in these trials was 79 , which ranged from 12 (278) to 295 (260). Only 3 trials evaluated heterogenous chronic non-cancer pain $(271,276,279)$, whereas 5 trials focused on back pain $(269,270,273,274)$. Two trials focused on neuropathic pain $(277,281)$ and 5 trials focused on osteoarthritis $(260,263,268,275,280)$ with only one study focusing on phantom limb pain (278). All of the trials were of relatively short duration, ranging from 5 days (272) to 16 weeks (274). Thus, these results may not even be applied to chronic pain management settings. Even then, withdrawal rates ranged from $0 \%$ to $45 \%$.

In a systematic review of opioid treatment for chronic back pain evaluating prevalence, efficacy, and association with addiction, Martell et al (10) evaluated multiple studies through 2005 and concluded that opioids are commonly prescribed for chronic back pain and maybe efficacious for short-term pain relief. However, long-term efficacy of more than 16 weeks was reported to be unclear. They also reported substance use disorders were common in patients taking opioids for back pain, and aberrant medication-taking behaviors occur in up to $24 \%$ of cases. Thus, this systematic review also has not provided any long-term evidence for opioid therapy of longer than 6 months.

Kalso et al (12) analyzed available randomized, placebo-controlled trials of the WHO step 3 opioids for efficacy and safety in chronic non-cancer pain through September 2003. Among the 15 randomized placebocontrolled trials they identified, 11 studies with 1,025 patients compared oral opioids with placebo for 4 days to 8 weeks. However, 8 of the 14 included trials had an open-label follow-up, 4 of oral morphine, 3 of oral oxycodone, and 1 of fentanyl (282-289). The mean decrease in pain intensity in most studies was at least $30 \%$ with opioids and was comparable in neuropathic and musculoskeletal pain. About $80 \%$ of patients experienced at least one adverse event with constipation $(41 \%)$, nausea $(32 \%)$, and somnolence $(29 \%)$ being most common. Only $44 \%$ of the 388 patients on openlabel treatment were still on opioids after therapy for between 7 and 24 months. They concluded that the short-term efficacy of opioids was good in both neuro- 
pathic and musculoskeletal pain conditions, whereas, only a minority of patients in these studies were onto long-term management with opioids, precluding any conclusion with regards to effectiveness on a longterm basis. Overall, they concluded that the mean relief with opioid was about $30 \%$. The lowest maximum doses, morphine $30 \mathrm{mg}$ and oxycodone $20 \mathrm{mg}$ daily were used in musculoskeletal pain and were not effective. Only 3 of the 8 studies found improvement in function or disability.

Furlan et al (13) also performed a meta-analysis of effectiveness and side effects of opioids with the inclusion of 41 randomized trials involving 6,019 patients with $80 \%$ of the patients suffering with nociceptive pain of osteoarthritis, rheumatoid arthritis, or back pain; $12 \%$ with neuropathic pain of post herpetic neuralgia, diabetic neuropathy, or phantom limb pain; $7 \%$ fibromyalgia; and $1 \%$ with mixed pain. They reported methodological quality of $87 \%$ of the studies as high. They also classified opioids as weak, which included tramadol, propoxyphene, and codeine or strong, which included morphine and oxycodone. However, hydrocodone was not included in either category. In this meta-analysis, they found that dropout rates averaged $33 \%$ in the opioid groups and $38 \%$ in the placebo group with average duration of treatment of 5 weeks, ranging from 1 to 16 weeks.

Ballantyne (6) and Ballantyne and Mao (14) performed a review of opioid therapy for chronic pain. In their review, they included 8 studies evaluating for 4 weeks or less, 7 studies for 12 weeks or less, and only 2 studies evaluated for a period of 14 weeks or longer with the longest duration being 24 weeks. They concluded that the only knowledge of long-term analgesic efficacy comes from surveys, case series, open-label follow-up studies in association with some RCTs, and epidemiological studies. Further, they concluded that surprisingly, only a few of the existing opioid studies have focused on function and quality of life.

Sandoval et al (18) performed a systematic review of methadone involving 21 papers with 545 patients with multiple non-cancer pain conditions. The methadone starting dose ranged from $0.2 \mathrm{mg}$ to $80 \mathrm{mg}$ per day with maximum doses of $20 \mathrm{mg}$ to $930 \mathrm{mg}$ per day. They reported statistical improvement in pain for methadone with $20 \mathrm{mg}$ per day compared to placebo in $59 \%$ of the cases, side effects in 225 patients with nausea and/or vomiting in $23 \%$, sedation in $18 \%$, itching and/or rash in $13 \%$, and constipation in $11 \%$ The results of oral methadone for chronic non-cancer pain are illustrated in Table 15 (18,290-294).

Cepeda et al (17) performed a systematic review and meta-analysis of 11 RCTs to determine the analgesic effectiveness, effect on physical function, the duration of benefit and safety of oral tramadol in patients with osteoarthritis. The study only included RCTs that evaluated the effect of tramadol or tramadol plus acetaminophen on pain levels in patients with opioid addiction (OA). Studies that evaluated other types of arthritis (e.g., rheumatoid arthritis), non-osteoarthritic joint pain, or back pain were excluded. The study concluded that tramadol is more effective than placebo for the treatment of OA when pain is moderate. However, when OA pain is severe, there is only a small benefit to the patient. The study also notes that tramadol tolerability is increased when a slow titration regimen is implemented (e.g. $100 \mathrm{mg} /$ day for 7-10 days, then $200 \mathrm{mg} /$ day). The study found this approach halves the proportion of people who interrupt therapy because of adverse events. Since only 2 studies evaluated tramadol for more than 8 weeks, the authors were unable to determine whether the clinical effectiveness of tramadol decreases with chronic use. Finally, another noted limitation was that only one of the 11 systematic reviews included in this study was not industry funded. Thus, it is possible for an overestimation of treatment effects of tramadol in patients with osteoarthritis.

Eisenberg et al (15) in a systematic review of opioids for neuropathic pain included 23 trials with 267 patients for short-term and 460 patients for intermediate term defining short-term as less than 8 days and intermediate term as 8 days to 10 weeks. They evaluated short-term trials of morphine, alfentanil, fentanyl, meperidine, and codeine, whereas, intermediate trial studies included morphine, oxycodone, methadone, and levorphanol. They reported mixed results with short-term trials of less than 8 days, whereas intermediate trials of 8 days to 10 weeks showing consistent opioid analgesic efficacy. They also reported nausea in $33 \%$, constipation in $33 \%$, drowsiness in $29 \%$, dizziness in $21 \%$, and vomiting in $15 \%$ with withdrawals in $11 \%$ of the patients.

Based on the information available from an extensive review of the literature, it appears that it is necessary to utilize less rigorous forms of evidence to evaluate long-term effectiveness, since it is not feasible to conduct RCTs over prolonged periods. Even in the open studies of long-term effectiveness, as many as $56 \%$ of patients abandon the treatment because 
Table 15. Characteristics of case series evaluating the effectiveness of methadone over 6 months.

\begin{tabular}{|c|c|c|c|c|}
\hline Study & Participants & Intervention & Outcomes & $\begin{array}{l}\text { Effectiveness } \\
\text { (no. Patients) }\end{array}$ \\
\hline $\begin{array}{l}\text { Robbins (290) } \\
\text { Ambulatory setting }\end{array}$ & $\begin{array}{l}66 \text { patients }(53 \mathrm{~F}, 13 \mathrm{M}) \text {, ages } \\
26 \text { to } 58 \text { y/o, with chronic } \\
\text { headaches. Indication for } \\
\text { methadone was ineffective } \\
\text { pain relief with previous } \\
\text { treatments: NSAIDs, } \\
\text { calcium channel blockers, } \\
\text { beta-blockers, valproate, and } \\
\text { antidepressants }\end{array}$ & $\begin{array}{l}\text { Average dose was } 10 \\
\text { mg/day. } \\
\text { Co-interventions: not } \\
\text { described. Time: } 6 \text { months } \\
\text { Side effects: fatigue, } \\
\text { confusion nausea, } \\
\text { constipation, profuse } \\
\text { sweating, lightheaded/ } \\
\text { dizziness, and rash }\end{array}$ & $\begin{array}{l}\text { Pain relief scale: } 1-25 \%=\text { no } \\
\text { relief: } 27 \text { patients }(41 \%) \\
25-50 \%=\text { mild relief }: 5 \\
\text { patients }(8 \%) 50-75 \%= \\
\text { moderate relief: } 16 \text { patients } \\
\text { (24\%) } 75-100 \%=\text { excellent } \\
\text { relief: } 18 \text { patients }(27 \%)\end{array}$ & $\begin{array}{l}\text { Meaningful }=34 \\
\text { Non-meaningful } \\
=32 \\
\text { Unclassifiable }=0\end{array}$ \\
\hline $\begin{array}{l}\text { Robbins (291) } \\
\text { Ambulatory setting }\end{array}$ & $\begin{array}{l}148 \text { patients. Only } 42 \\
\text { remained on methadone } \\
\text { after } 6 \text {-mos period ( } 33 \mathrm{~F} \text {, } \\
9 \mathrm{M}) \text {. With chronic daily } \\
\text { headache refractory to } \\
\text { standard therapies such as } \\
\text { NSAIDs, calcium channel } \\
\text { blockers, divalproex, } \\
\text { antidepressants, and } \\
\text { methysergide }\end{array}$ & $\begin{array}{l}\text { Average dose was } 10 \\
\text { mg/day. } \\
\text { Co-interventions: not } \\
\text { described. } \\
\text { Time: } 6 \text { months } \\
\text { Complications and side } \\
\text { effects: not described }\end{array}$ & $\begin{array}{l}42 \text { reported moderate or } \\
\text { excellent relief. Quality } \\
\text { of work and home life in } \\
\text { these } 42 \text { patients: } 86 \% \text { of } \\
\text { patients had improvement } \\
\text { in work performance; } 71 \% \\
\text { improvement in relationship } \\
\text { with partner; } 81 \% \\
\text { improvement in relationship } \\
\text { with } \\
\text { children and friends; } 60 \% \\
\text { improvement in sexuality }\end{array}$ & $\begin{array}{l}\text { Meaningful }=42 \\
\text { Non-meaningful } \\
=106 \\
\text { Unclassifiable }=0\end{array}$ \\
\hline $\begin{array}{l}\text { Mironer et al (292) } \\
\text { Ambulatory setting }\end{array}$ & $\begin{array}{l}47 \text { patients ( } 18 \mathrm{~F}, 29 \mathrm{M}), 57 \\
\text { y/o on average (from } 29 \text { to } \\
88 \text { ), with neuropathic pain. } \\
\text { Indication for methadone } \\
\text { was ineffectiveness with } \\
\text { previous treatments: } \\
\text { opioids, anticonvulsants, } \\
\text { antidepressants, calcium } \\
\text { channel blockers, } \\
\text { intravenous and oral } \\
\text { lidocaine, etc. }\end{array}$ & $\begin{array}{l}\text { Average daily intake of } \\
\text { methadone was } 27 \mathrm{mg} / \text { day } \\
\text { (range } 10-60 \mathrm{mg} / \text { day) } \\
\text { The most common co- } \\
\text { intervention: gabapentin } \\
\text { (12 patients). Duration of } \\
\text { treatment varied from } 6 \text { to } \\
37 \text { months }\end{array}$ & $\begin{array}{l}\text { Patients reported on average } \\
30 \% \text { to } 90 \% \text { pain relief, with } \\
34 \text { out of } 47 \text { having more } \\
\text { than } 50 \% \text { improvement } \\
\text { in their pain scores. Side } \\
\text { effects: not significant }\end{array}$ & $\begin{array}{l}\text { Meaningful }=47 \\
\text { Non-meaningful }=0 \\
\text { Unclassifiable }=0\end{array}$ \\
\hline $\begin{array}{l}\text { Quang-Cantagrel et al (293) } \\
\text { Ambulatory setting }\end{array}$ & $\begin{array}{l}\text { Methadone was given to } 29 \\
\text { patients out of } 86(50 \mathrm{~F}, 36 \\
\text { M) with various non-cancer } \\
\text { pain syndromes (back } \\
\text { pain neuropathy: joint } \\
\text { pain, visceral pain, reflex } \\
\text { sympathetic dystrophy, } \\
\text { headache, and fibromyalgia } \\
\text { Indication for methadone } \\
\text { was ineffectiveness with } \\
\text { previous treatments }\end{array}$ & $\begin{array}{l}\text { Doses of methadone were } \\
39.0617 .0 \mathrm{mg} / \text { day. } \\
\text { Co-interventions: not } \\
\text { described. } \\
\text { Duration of the treatment } \\
\text { was an average of } 49.4 \text { wks }\end{array}$ & $\begin{array}{l}\text { There was } 1 \text { case of } \\
\text { addiction and no case of } \\
\text { tolerance } \\
\text { Complications and side } \\
\text { effects (52\%) included: } \\
\text { nausea, vomiting, sedation, } \\
\text { itching, and kidney } \\
\text { alterations }\end{array}$ & $\begin{array}{l}\text { Meaningful }=8 \\
\text { Non-meaningful } \\
=21 \\
\text { Unclassifiable }=0\end{array}$ \\
\hline $\begin{array}{l}\text { Moulin et al (294) } \\
\text { Ambulatory setting }\end{array}$ & $\begin{array}{l}50 \text { patients }(22 \mathrm{~F}, 28 \mathrm{M}) \\
\text { with mean age of } 52.7 \text { and } \\
\text { a variety of intractable } \\
\text { neuropathic pains. } \\
\text { The indications were } \\
\text { ineffectiveness of previous } \\
\text { medications and side effects }\end{array}$ & $\begin{array}{l}\text { Initial dose of } 20 \mathrm{mg} \text { /day. } \\
\text { Maximum dose } 160 \mathrm{mg} / \\
\text { day Maintenance dose } 121 \\
\text { mg/day. } \\
\text { Co-interventions: tricyclic } \\
\text { antidepressants, NSAIDs, } \\
\text { SSRI, benzodiazepines, and } \\
\text { anticonvulsants. } \\
\text { Mean duration of } \\
\text { treatment: } 17.3 \text { months }\end{array}$ & $\begin{array}{l}26(52 \%) \text { improved with } \\
\text { methadone: } 3 \text { mild, } 16 \\
\text { moderate, } 6 \text { marked, and } \\
1 \text { complete pain relief } 16 \\
\text { patients ( } 32 \%) \text { reported } \\
\text { improvement in function } \\
\text { Complications and side } \\
\text { effects: not described }\end{array}$ & $\begin{array}{l}\text { Meaningful }=23 \\
\text { Non-meaningful } \\
=27 \\
\text { Unclassifiable }=0\end{array}$ \\
\hline
\end{tabular}

Adapted from Trescot et al (19). Effectiveness of opioids in the treatment of chronic non-cancer pain. Pain Physician 2008; 11:S181-S200. 
of lack of efficacy or side effects $(9,12)$. In addition, it has been described that many opioid trials utilize enrichment in their protocols with removal of patients who do not respond, also known as selecting out during the pre-trial phase with an additional unusually high drop-out rate across opioid trials during enrichment, compromising the internal validity of these trials $(6,295)$. Further, functional status improvement has been studied meagerly and the results have been poor.

\subsubsection{Effectiveness of Individual Drugs}

In the United States, the most commonly used therapeutic opioids in the order of maximum use are as follows: oxycodone, hydrocodone, codeine, morphine, and methadone. Transdermal fentanyl is the least used opioid behind meperidine and hydromorphone. However, the available evidence is better for sustained-release morphine and transdermal fentanyl, compared to all other drugs, though weak.

\section{Morphine}

Allan et al (259) evaluated sustained release oral morphine in 342 strong-opioid naïve patients with chronic low back pain with assessment of pain relief, quality of life, disease progression, and side effects, including bowel function. Sustained release morphine provided significant improvement of mean VAS scores for patients who remained in the study for 56 weeks. However, use of concomitant, strong, short-acting opioids was frequent in $50 \%$ of the patients as rescue medication. While quality of life scores showed improvement in physical health, there was no significant difference with mental health. They concluded that strong opioids may be indicated for chronic low back pain that is not relieved by other forms of analgesia

Caldwell et al (260), in an open-label extension trial evaluated Avinza $\otimes$ an extended-release morphine formulation, in 181 patients during the 26-week openlabel extension trial. Significant reductions in pain intensity and improved sleep measures were observed. However, improvements were not observed in physical function. Twenty-eight or $15 \%$ of patients were excluded entirely from the subset analysis due to concomitant therapy with NSAIDs and/or acetaminophen use. Constipation and nausea were the most frequent adverse effects reported in over $80 \%$ of the patients.

Zenz et al (265) evaluated long-term oral opioid therapy in 100 patients with chronic non-cancer pain, utilizing either sustained-release morphine, dihydrocodeine, or buprenorphine, with 23 patients in the morphine group. Good pain relief was obtained in 51 patients, partial pain relief was reported by 28 patients, and 21 patients reported no beneficial effect from opioid therapy. The most common side effects were constipation and nausea.

Maier et al (296) evaluated long-term efficacy of morphine in 121 patients with chronic non-cancer pain, 5 years after the onset of medical treatment. Frequency of withdrawal was $14.8 \%$ mainly due to lack of efficacy with an average treatment time of 66 months (37-105 months with $87 \%$ more than 5 years). The study showed that patients with long-term opioid intake exhibited significantly lower pain intensity and higher contentment with the pain management and improvement in physical status and quality of life. There were inconsistent changes in opioid dosages over the period of 5 years, without any change in $33 \%$ of the patients, with decrease in $16 \%$, slight increase in $27 \%$, and high increase in $19 \%$. The survey demonstrated a very low frequency of withdrawal in patients with long-term opioid medication after initial response without evidence for tolerance development, especially if their treatment was controlled in a pain center.

Tassian et al (297) evaluated the long-term effects of sustained release morphine on neuropsychological performance in patients with chronic non-cancer pain. Of the 28 patients initially included in the study, 18 patients received oral sustained morphine on a longterm basis with significant improvement in pain, function, and mood. Morphine induced persisting effects on pain, and to a lesser extent on quality of life and mood at 12 months, with no disruption of cognitive function.

Table 13 illustrates results of multiple studies evaluating the long-term effectiveness of morphine.

\section{Transdermal Fentanyl}

Allan et al (259) evaluated 338 patients with chronic low back pain with transdermal fentanyl for a period of 13 months. The proportion of patients experiencing a $50 \%$ or greater improvement in back pain was observed to be $40 \%$ in the patients with rest, $47 \%$ on movement and during the day, and $53 \%$ in patients at night. Concomitant medication with possible analgesic effect and rescue medication during the trial was seen in greater than $80 \%$ of the patients with $52 \%$ using strong opioids.

Milligan et al (266) evaluated long-term efficacy and safety of transdermal fentanyl in the treatment of chronic non-cancer pain in an international, multicenter, open-label trial over a period of 12 months, 
with completion of the trial by $301(57 \%)$ of the patients. An average of $67 \%$ of patients within the efficacy analysis group ( $n=524)$ reported very good, good, or moderate pain control, with global satisfaction reported in $42 \%$ of the patients. The majority ( $86 \%$ ) of patients reported a preference for transdermal fentanyl over their previous treatment. There was significant improvement in the bodily pain scores of Short Form 36. The most frequent treatment-related adverse events were nausea (31\%), constipation (19\%), and somnolence (18\%).

Mystakidou et al (267) evaluated the effectiveness of transdermal fentanyl in the long-term management of non-cancer pain, in 529 patients in a prospective open-label study. The mean duration of therapy for effective pain management was 10 months, and $90 \%$ of patients sustained effectiveness with improvement in quality of life scores and pain. Further, the improvements were not influenced by pain type or etiology.

Table 14 illustrates the results of studies evaluating long-term effectiveness of transdermal fentanyl.

\section{Oxycodone}

The effectiveness of oxycodone was evaluated in multiple studies $(286,298-300)$.

Portenoy et al (300) looked at sustained release oxycodone use over a 3-year period in 233 non-cancer patients who had participated earlier in clinical trials regarding the same medication. At study's end, pain was the same or improved in $70 \%$ to $80 \%$ of the patients. They noted that approximately $50 \%$ of the patients stopped the opioids due to side effects in the first 6 months. Adverse effects were seen in $88 \%$ of the patients on sustained release oxycodone.

Rauck et al (298), in a randomized, open-label, multicenter trial, studied the effectiveness of sustained release oxycodone comparing it with sustained release morphine in 266 patients up to 8 months. Both groups showed significant improvement. The concluded that compared to twice daily sustained release oxycodone, once daily sustained release morphine resulted in significantly better physical function and quality of life.

Roth et al (264) studied 133 patients with osteoarthritis with follow-up lasting up to 6 months. Fifty-eight patients completed 6 months of treatment and 41 completed 12 months of follow-up, whereas 15 completed 18-month follow-up. They concluded that sustained release oxycodone provided sustained analgesia.

Hermos et al (299) in an observational review reported the results of 47,000 veterans receiving opioids through the VA system of which 2,200 received oxycodone for over 9 months however, $31 \%$ of these patients were diagnosed with cancer with mean daily doses of 3.9 tablets per day with a range of 0.5 to 13 with minimum change over time.

Table 16 illustrates the results of studies evaluating oxycodone.

\section{Hydrocodone}

There were no studies evaluating the effectiveness of hydrocodone even though this is the most commonly used drug.

\section{Methadone}

Fredheim et al (262) studied 8 chronic non-cancer patients experiencing insufficient pain control or intolerable side effects during treatment with oral morphine who switched to oral methadone. They showed that opioid switching from low doses of oral morphine to an equi-analgesic oral methadone causes a small but statistically significant increase in QTc time.

Fredheim et al (301) showed that, after switching 12 patients from morphine to methadone, their blood levels and metabolite levels remained steady for the 9-month study period, contradicting the hypothesis of metabolic tolerance and auto-induction of hepatic enzymes during long-term methadone therapy. However, they noted that the oral dose had a poor correlation with serum blood levels, confirming a large inter-individual variability of metabolism.

Sandoval et al (18), in a systematic review of oral methadone for chronic non-cancer pain described the effectiveness of methadone in multiple observational studies as shown in Table 15.

\section{Tramadol}

Cepeda et al (17) performed a systematic review and meta-analysis of multiple randomized trials.

Controlled-release tramadol was evaluated by Beaulieu et al (302) in a multi-center, randomized, double blind, double dummy, 8-week crossover study, comparing it to immediate release tramadol. Overall pain scores were significantly better with the controlled release formulation. Since tramadol has a serotonin and norepinephrine reuptake inhibition action, continuous dosing (such as seen with extended release formulations) would be expected to be more effective than intermittent dosing (since the intermediate dosing does not allow for accumulation of serotonin and norepinephrine).

Adams et al (303), in a study funded by OrthoMcNeil, performed a double blind, 12-month crossover trial, looking at 3 different treatment arms: tramadol alone, tramadol randomized against 
Table 16. Results of studies evaluating long-term effectiveness of oxycodone.

\begin{tabular}{|c|c|c|c|c|c|c|}
\hline Study/ methods & Participants & Opioids studied & Outcome(s) & Result(s) & Conclusion(s) & Complications \\
\hline $\begin{array}{l}\text { Rauck et al (298) } \\
\text { Randomized, open- } \\
\text { label, multicenter } \\
\text { trial }\end{array}$ & $\begin{array}{l}\text { Chronic, severe } \\
\text { low back pain } \\
(\mathrm{n}=266) \\
\text { Sustained release } \\
\text { morphine vs. } \\
\text { sustained release } \\
\text { oxycodone } \\
\text { Up to } 8 \text { months }\end{array}$ & $\begin{array}{l}\text { Randomized to } \\
\text { sustained release } \\
\text { morphine (Avinza) } \\
\text { or sustained } \\
\text { release oxycodone } \\
\text { (Oxycontin) } \\
\text { period of dose } \\
\text { titration, then } 8 \\
\text { week evaluation } \\
\text { and optional } 4 \\
\text { month extension } \\
\text { (n=174) }\end{array}$ & $\begin{array}{l}\text { Short Form- } \\
\text { 12, Work } \\
\text { Limitation } \\
\text { Questionnaire }\end{array}$ & $\begin{array}{l}\text { Improvements seen } \\
\text { in both groups ( }> \\
\text { in sustained release } \\
\text { morphine) }\end{array}$ & $\begin{array}{l}\text { Compared to } \\
\text { twice a day } \\
\text { sustained release } \\
\text { oxycodone, once } \\
\text { daily sustained } \\
\text { release morphine } \\
\text { resulted in } \\
\text { significantly better } \\
\text { physical function } \\
\text { and quality of life } \\
\text { activities. }\end{array}$ & None described \\
\hline $\begin{array}{l}\text { Roth et al (264) } \\
\text { Randomized, } \\
\text { double blind, } \\
\text { placebo controlled }\end{array}$ & $\begin{array}{l}133 \text { patients with } \\
\text { osteoarthritis } \\
6 \text { to } 12 \text { months } \\
58 \text { patients } \\
\text { completed } \\
6 \text { months } \\
\text { treatments, } \\
41 \text { completed } \\
12 \text { months, } 15 \\
\text { completed } 18 \\
\text { months }\end{array}$ & $\begin{array}{l}\text { Sustained release } \\
\text { oxycodone bid } \\
10 \mathrm{mg}(\mathrm{n}=44) \\
20 \mathrm{~m}(\mathrm{n}=44) \\
\text { vs placebo }(\mathrm{n}=45)\end{array}$ & $\begin{array}{l}\text { VAS, mood, } \\
\text { sleep, quality } \\
\text { of life }\end{array}$ & $\begin{array}{l}\text { Mood and quality } \\
\text { of life improved. } \\
\text { Analgesia was } \\
\text { maintained and } \\
\text { dose was stable }\end{array}$ & $\begin{array}{l}\text { Sustained release } \\
\text { oxycodone } \\
\text { provided sustained } \\
\text { analgesia }\end{array}$ & $\begin{array}{l}\text { Typical opioid } \\
\text { side effects } \\
\text { were noted and } \\
\text { decreased over } \\
\text { time }\end{array}$ \\
\hline $\begin{array}{l}\text { Hermos et al (299) } \\
\text { Observational } \\
\text { review }\end{array}$ & $\begin{array}{l}47,000 \text { veterans } \\
\text { receiving opioids } \\
\text { through the VA } \\
\text { system }\end{array}$ & $\begin{array}{l}\text { Oxycodone with } \\
\text { APAP; } \\
\text { concurrent use } \\
\text { of long acting } \\
\text { narcotics, } \\
\text { benzodiazepines, } \\
\text { tricyclic } \\
\text { antidepressants, } \\
\text { and anti-epileptic } \\
\text { drugs }\end{array}$ & $\begin{array}{l}\text { Number of } \\
\text { doses }\end{array}$ & $\begin{array}{l}\text { About } 2,200 \\
\text { received oxycodone } \\
\text { with APAP for }> \\
9 \text { months ( } 31 \% \\
\text { with diagnosis of } \\
\text { cancer); mean daily } \\
\text { dose } 3.9 \text { tabs/day } \\
\text { (0.5-13.0) with } \\
\text { minimal change } \\
\text { over time }\end{array}$ & $\begin{array}{l}\text { Among patients } \\
\text { without cancer, } \\
\text { patients with } \\
\text { concurrent } \\
\text { benzodiazepines, } \\
\text { psychogenic pain, } \\
\text { alcohol abuse, and } \\
\text { HIV/AIDS had } \\
\text { more prescription } \\
\text { management } \\
\text { problems }\end{array}$ & None described \\
\hline $\begin{array}{l}\text { Portenoy et al (300) } \\
\text { Open label, } \\
\text { uncontrolled } \\
\text { registry }\end{array}$ & $\begin{array}{l}233 \text { patients } \\
\text { non-cancer pain } \\
\begin{array}{l}\text { Low back pain ( } 68 \\
\text { patients) }\end{array} \\
\begin{array}{l}\text { Neuropathic ( } 67 \\
\text { patients) }\end{array} \\
\begin{array}{l}\text { Osteoarthritis ( } 84 \\
\text { patients) }\end{array}\end{array}$ & $\begin{array}{l}\text { Sustained release } \\
\text { oxycodone } \\
1 \text { yr (141 pts) } \\
2 \text { yrs ( } 86 \text { pts) } \\
3 \text { yrs (39 pts) }\end{array}$ & $\begin{array}{l}\text { Brief Pain } \\
\text { Inventory } \\
\text { Short Form, } \\
\text { VAS, med } \\
\text { acceptability, } \\
\text { adverse events, } \\
\text { aberrant drug } \\
\text { behavior } \\
\text { (abuse, misuse, } \\
\text { withdrawal) }\end{array}$ & $\begin{array}{l}\text { Brief Pain } \\
\text { Inventory Short } \\
\text { Form scores } \\
\text { decreased after } \\
\text { starting oxycodone. } \\
\text { Pain scores } \\
\text { improved in } \\
\text { approximately } 70 \text { to } \\
80 \% \text { thru month } 33 \\
\text { and } 54 \% \text { at month } \\
36 \text {. }\end{array}$ & $\begin{array}{l}\text { There need to } \\
\text { be more data } \\
\text { regarding efficacy } \\
\text { of long-term } \\
\text { opioids }\end{array}$ & $\begin{array}{l}\text { Adverse events } \\
\text { seen in } 88 \% \\
\text { sustained release } \\
\text { oxycodone. } \\
\text { Constipation } \\
(15 \%) \text {, nausea } \\
(12 \%) \text {, } \\
\text { somnolence } \\
(8 \%) \text {, vomiting } \\
(7 \%) \text {, depression } \\
(2 \%) .7 \\
\text { patients died, } \\
\text { presumably } \\
\text { not related to } \\
\text { medication. }\end{array}$ \\
\hline
\end{tabular}

Adapted from Trescot et al (19). Effectiveness of opioids in the treatment of chronic non-cancer pain. Pain Physician 2008; 11:S181-S200. 
NSAIDs, and tramadol randomized against hydrocodone. They looked at pain scores, SF-36, and what they called an "abuse index." They found that the prevalence of abuse/dependence over the 12-month period was equal for the tramadol and NSAIDs, but, as expected, the hydrocodone had twice as much abuse.

Table 17 illustrates results of studies of tramadol.

Table 17. Results of studies evaluating long-term effectiveness of tramadol.

\begin{tabular}{|c|c|c|c|c|c|c|}
\hline Study/methods & Participants & Opioids studied & Outcome(s) & Result(s) & Conclusion(s) & Complications \\
\hline $\begin{array}{l}\text { Harati et al (261) } \\
\text { 6-month open } \\
\text { extension followed } \\
\text { a 6-week double- } \\
\text { blind randomized } \\
\text { trial }\end{array}$ & 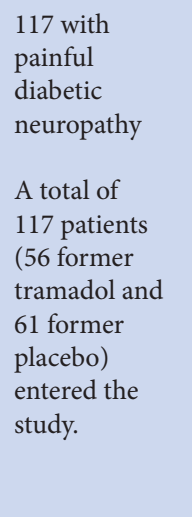 & Tramadol & $\begin{array}{l}\text { Self-administered } \\
\text { pain intensity } \\
\text { scores (scale } 0-4 \text {; } \\
\text { none to extreme } \\
\text { pain) and pain } \\
\text { relief scores (scale } \\
\text {-1-4; worse to } \\
\text { complete relief) } \\
\text { were recorded the } \\
\text { first day of the } \\
\text { open extension } \\
\text { (last day of the } \\
\text { double-blind } \\
\text { phase) and at } 30 \text {, } \\
90 \text {, and } 180 \text { days. }\end{array}$ & $\begin{array}{l}\text { Tramadol } \\
\text { reduced } \\
\text { mean pain } \\
\text { scores } \\
\text { which were } \\
\text { maintained } \\
\text { throughout } \\
\text { the study }\end{array}$ & $\begin{array}{l}\text { Tramadol } \\
\text { provides long- } \\
\text { term relief of the } \\
\text { pain of diabetic } \\
\text { neuropathy }\end{array}$ & $\begin{array}{l}\text { The most common } \\
\text { adverse events } \\
\text { were constipation, } \\
\text { nausea, and } \\
\text { headache }\end{array}$ \\
\hline $\begin{array}{l}\text { Adams et al (213) } \\
\text { Prospective }\end{array}$ & $\begin{array}{l}\text { A total of } \\
11,352 \text { subjects } \\
\text { were enrolled }\end{array}$ & $\begin{array}{l}\text { NSAIDs, } \\
\text { tramadol, } \\
\text { hydrocodone }\end{array}$ & Abuse & $\begin{array}{l}\text { Tramadol was } \\
\text { effective with } \\
\text { less abuse } \\
\text { potential than } \\
\text { hydrocodone }\end{array}$ & $\begin{array}{l}\text { These results } \\
\text { support the } \\
\text { hypothesis that } \\
\text { the rate of abuse } \\
\text { identified with } \\
\text { tramadol is less } \\
\text { than the rate } \\
\text { associated with } \\
\text { hydrocodone }\end{array}$ & None described \\
\hline $\begin{array}{l}\text { Beaulieu et al (302) } \\
\text { Multicenter } \\
\text { randomized double } \\
\text { blind, double } \\
\text { dummy, cross over } \\
\text { trial of tramadol } \\
\text { controlled-release } \\
\text { and tramadol } \\
\text { immediate-release }\end{array}$ & $\begin{array}{l}\text { Chronic non } \\
\text { cancer pain } \\
\text { patients: }(\mathrm{n}= \\
\text { 122) } \\
\text { Completed } \\
\text { study: } \mathrm{n}=65 \\
8 \text { weeks }\end{array}$ & $\begin{array}{l}\text { Pts randomized } \\
\text { to } 2 \text { groups: } \\
\text { active tramadol } \\
\text { controlled- } \\
\text { release + placebo } \\
4-6 \text { hours prn } \\
\text { or placebo plus } \\
\text { active tramadol } \\
\text { immediate-release } \\
4-6 \text { hours prn } \\
\text { for } 4 \text { weeks and } \\
\text { then switched } \\
\text { to alternate } \\
\text { treatment for } \\
\text { another } 4 \text { weeks }\end{array}$ & $\begin{array}{l}\text { Pain intensity; pain } \\
\text { disability index; } \\
\text { sleep quality and } \\
\text { quantity; analgesic } \\
\text { effectiveness; } \\
\text { adverse events at } \\
\text { each visit }\end{array}$ & $\begin{array}{l}\text { Overall pain } \\
\text { intensity } \\
\text { scores } \\
\text { significantly } \\
\text { better with } \\
\text { controlled- } \\
\text { release } \\
\text { tramadol. } \\
\text { No } \\
\text { differences } \\
\text { in total pain } \\
\text { disability } \\
\text { index, or } \\
\text { overall pain } \\
\text { and sleep } \\
\text { scores }\end{array}$ & $\begin{array}{l}\text { Significantly } \\
\text { better pain } \\
\text { control in chronic } \\
\text { benign pain } \\
\text { with tramadol } \\
\text { controlled-release } \\
\text { every } 24 \text { hours } \\
\text { vs. Tramadol } \\
\text { immediate-release } \\
\text { every } 4-6 \text { hours } \\
\text { prn } \\
\text { Funded by Purdue } \\
\text { Pharma }\end{array}$ & $\begin{array}{l}3 \text { patients } \\
\text { experienced serious } \\
\text { adverse events. } \\
\text { The only difference } \\
\text { in adverse events } \\
\text { was nausea seen } \\
\text { more often in } \\
\text { the tramadol } \\
\text { controlled-release } \\
\text { ( }<0.021 \text { ). } \\
2 \text { patients } \\
\text { hospitalized with } \\
\text { vomiting from } \\
\text { the immediate- } \\
\text { release group; one } \\
\text { hospitalized for } \\
\text { asthenia in the } \\
\text { controlled-release } \\
\text { group }\end{array}$ \\
\hline
\end{tabular}

Adapted from Trescot et al (19). Effectiveness of opioids in the treatment of chronic non-cancer pain. Pain Physician 2008; 11:S181-S200. 


\section{Oxymorphone}

Rauck et al (304) studied oxymorphone in an open-label 6-month study looking at efficacy and side effects. They reported $75 \%$ of patients could be stabilized on a dose of oxymorphone that provided effective pain relief with tolerable side effects.

Mcllwain and Ahdieh (263), in a 52-week, multicenter open-label extension study of 153 patients with moderate to severe chronic osteoarthritis-related pain, showed improvement in pain. They found that oxymorphone ER provides a new 12-hour analgesic for the treatment of moderate to severe, chronic osteoarthritis-related pain in patients who may require longterm opioid therapy.

\subsection{Summary of Evidence}

Based on the review of multiple systematic reviews and the available literature, the evidence for the effectiveness of long-term opioids in reducing pain and improving the functional status for 6 months or longer is variable. The evidence for transdermal fentanyl and sustained-release morphine is Level II-2 based on the quality of evidence criteria described by the U.S. Preventive Services Task Force as illustrated in Table 1 (26). For oxycodone, the level of evidence is II-3, however, for hydrocodone and methadone, the level of evidence is III.

\subsection{Recommendation}

Based on the review of multiple systematic reviews and the available literature, the recommendation is $2 \mathrm{~A}$ - weak recommendation, high-quality evidence with benefits closely balanced with risks and burden; derived from RCTs without important limitations or overwhelming evidence from observational studies; with the implication that with a weak recommendation, best action may differ depending on circumstances or patients' or societal values.

\subsection{Adherence Monitoring}

\subsection{Introduction}

Important issues in opioid therapy in chronic pain revolve around appropriate use of prescription opioids. Patients that describe symptoms of pain, and lack of relief, are one of the most common patient populations in the primary care community. Perceived interference of activities of daily living creates the perception of a need of drugs, and sometimes these patients are divulging signs and symptoms that may threaten the patient-physician relationship that is built on trust. The primary care physician is ill equipped to handle these patients, they rapidly lose control, and then they often are referred to the pain management physician as a "risk shift." These patients expect something to be done, and are often promised that the pain clinic will maintain the same level of care. It is the pain physician's responsibility to define their personal risk tolerance. Many times the primary care physician will not engage in opioid agreements and not fully explore non-narcotic medication alternatives. Adherence monitoring is crucial to avoid abuse of the drugs and at the same time to encourage appropriate use, and involves the initiation of drug screening, pill counts, and patient care agreements, with the motto of "trust but verify."

A high-risk practice, such as a pain management practice, will readily activate an adherence monitoring program, utilize advanced documentation, have a strong office policy, a threshold policy, and will define how many patients of this nature will be treated in the practice. If available, a second opinion from an addictionologist or psychologist may be advised, and a high-risk practice should understand that these charts should be readily available for the Board of Medical Examiners to review for legitimate need. Frequent functional assessments are mandatory. The risk environment is increased with Medicaid and disabled patients, patients with a previous history of substance abuse, and psychiatric disorders, particularly bipolar personalities, borderline personalities, history of alcohol abuse, and chaotic home environment. Boundary violations, which unfortunately do occur in this patient population, are never acceptable, and a difficult patient is best chaperoned at each visit.

The high-risk patient may have an abnormal pill count or drug screen. The patient that is discharged from a previous practice will have a documented historical reason, and records from this previous practice are recommended. High risk includes discharge from a previous practice, chaotic lifestyle, recent arrival to the area, poor response to multimodality approach to pain, sedentary lifestyle, cigarette smoker, and possibly obesity. Also patients that are litigating, disabled, and on Medicaid may also be at higher risk and may require more adherence monitoring. Patients should be expected to take a proactive role in their own healthcare. The risk/reward of the relationship is constantly reassessed. The patient should understand that pills kill, pain does not. The concept of legitimate 
medical need is reviewed with the patient, and function, adherence, compliance, and comanaging physicians are sometimes called upon.

Confusion surrounding a specific operational definition of opioid misuse among chronic pain patients has complicated the process of effectively assessing and predicting its occurrence (159). The typical elements of drug diversion involve theft, forgery, counterfeit prescriptions, fraud imposed against physician/pharmacy for other patients, and promoting pill mills (1-4).

There is a need for better tamper-proof opioids. As long as long-acting opioids can be easily converted into a rapidly absorbed form, there will be a effort to divert these medications for illicit use.

\subsection{Screening for Opioid Abuse}

The decision to use opioids for chronic pain patients, like all medical decisions, is based on a balance between risk and potential benefit. Screening for opioid misuse and abuse is an exercise to strengthen the patient-physician relationship. This should not be confrontational, and the patient has to understand that this is like any other lab test. A physician would respond to abnormal liver functions or anemia, just as a pain physician responds to a screening questionnaire, urine drug screen, or pill count.

Even though several investigators have described multiple screening instruments in detecting opioid abuse or misuse in chronic pain patients, there is no widely used screening instrument in the current practice. Most look at problematic behaviors such as focusing on opioids, escalation of opioid use, multiple phone calls and visits, lack of improvement with increased medications, multiple prescription problems (lost or stolen scripts), and opioids from multiple providers (159).

\subsection{Urine Drug Testing (UDT)}

Although drug testing may be performed by testing the urine, serum, or hair, urine is considered as the best biologic specimen for detecting the presence or absence of certain drugs due to specificity, sensitivity, ease of administration, and the cost. However, controversies exist regarding the clinical value of UDT, partly because most current methods were designed for, or adapted from, forensic or occupational deterrent-based testing for illicit drug use and are not necessarily optimized for clinical applications in chronic pain management. In chronic pain management, UDT should be used with an appropriate level of understanding (which can improve a physician's professional ability to manage therapeutic prescription drugs with controlled substance), and to diagnose substance abuse or appropriate intake of drugs, thereby leading to proper treatment. They should be random, well organized, and synchronized with a well-understood testing lab. The lab understands you, and you understand what they are testing. False-positives, negatives, and the scope of testing should also be understood.

It is also critical to understand the metabolism of opioids, to avoid falsely accusing patients of abuse. For instance, codeine is metabolized to morphine, and hydrocodone to hydromorphone. However, it has only been recognized recently that morphine (in high doses) can be metabolized to hydromorphone (305). The hydromorphone is usually about $2 \%$ of the morphine dose (which can be determined by quantitative testing), and is usually seen in patients taking at least 100 to $200 \mathrm{mg}$ morphine per day. In a retrospective case-control study (306), $66 \%$ of patients on morphine showed evidence of hydromorphone in the UDT; this was seen more commonly in females, despite the fact that the females were taking lower doses of morphine.

In principle, UDTs can detect the parent drug and/or its metabolite(s) and, therefore, demonstrate recent use of prescription medications and illegal substances. For most clinical applications, initial testing is done with class-specific immunoassay drug panels, which typically do not identify individual drugs within a class. However, this may, and perhaps should, be followed by a more specific technique such as a gas chromatography/mass spectrometry (GC/MS) to identify or confirm the presence or absence of a specific drug and/or its metabolite(s). Numerous differences between various tests and even among the laboratories and manufacturers of various rapid drug screen tests include the number of drugs tested, cross-reactivity patterns, cut-off concentrations, and drug interferences. Clinicians should remember that the cut-off concentrations used for drugs in federally regulated testing, particularly opioids, are too high to be of value in clinical practice. Federally regulated testing includes 5 drugs or drug classes that are tested for in federal employees and federally regulated industries, including marijuana, cocaine, opiates, PCP, and amphetamines/methamphetamines, with pre-determined cut-off levels with mandatory reconfirmation with the results by GC/MS, along with split sample in chain of custody requirements. In contrast, nonregulated testing is used for many purposes, including monitoring pain patients clinically. 
In clinical practice, UDT is used for accurate record keeping, to identify use of undisclosed substances, to uncover diversion or trafficking, and to determine appropriate intake of prescribed substances. There are typically 2 types of UDT. These approaches used in proper combination can reduce cost, ensure accuracy, and improve efficiency. The 2 main types of UDT methods are:

1) Immunoassay drug testing, either laboratory based or by rapid drug testing ("site of service").

2) Laboratory-based specific drug identification with GC/MS, high-performance liquid chromatography (HPLC), etc.

Immunoassays, which are based on the principle of competitive binding, use antibodies to detect the presence of a particular drug or metabolite in a urine sample. Immunoassay drug testing is provided either in the laboratory or by means of rapid drug testing at the point of service. An immunoassay's ability to detect drugs will vary according to the drug concentration in the urine and the assay's cut-off concentration. Any response above the cut-off is deemed positive and any response below the cutoff is negative. Further, immu- noassays are subject to cross-reactivity. For example, tests for cocaine are highly predictive of cocaine use. In contrast, tests for amphetamine/methamphetamine are highly cross-reactive and unreliable. They may detect other sympathomimetic amines such as ephedrine and pseudoephedrine and, therefore, are not very predictive for amphetamine/methamphetamine use. Further, standard tests for opiates are very responsive for morphine and codeine (but do not distinguish the difference), but show a lower sensitivity for semisynthetic/synthetic opioids such as oxycodone, fentanyl, methadone, and buprenorphine, such that a negative response does not exclude use of these opioids. Specific immunoassay tests for semisynthetic/synthetic opioids are available.

Table 18 illustrates cut-off levels for various drugs detected by urine analysis. Ideally, a panel in chronic pain management settings for rapid drug screening should include not only opiates, but also oxycodone and methadone. In addition, the panel should include cocaine, marijuana, amphetamines and methamphetamines for illicit drugs and benzodiazepines and barbiturates for other controlled substances. If

Table 18. Urine drug testing: Typical screening and confirmation cutoff concentrations and detection times for drugs of abuse.

\begin{tabular}{|c|c|c|c|c|c|}
\hline Drug & $\begin{array}{l}\text { Screening } \\
\text { cutoff } \\
\text { concentrations } \\
\text { ng/mL urine }\end{array}$ & $\begin{array}{l}\text { Analyte tested in } \\
\text { confirmation }\end{array}$ & $\begin{array}{c}\text { Confirmation } \\
\text { cutoff } \\
\text { concentrations } \\
\text { ng/mL } \\
\text { (non-regulated) }\end{array}$ & $\begin{array}{c}\text { Confirmation } \\
\text { cutoff } \\
\text { concentrations } \\
\text { ng/mL } \\
\text { (federally } \\
\text { regulated) } \\
\end{array}$ & Urine detection time \\
\hline Amphetamine & 1,000 & Amphetamine & 500 & 1,000 & 2-4 days \\
\hline Barbiturates & 200 & $\begin{array}{l}\text { Amobarbital, } \\
\text { secobarbital, other } \\
\text { barbiturates }\end{array}$ & 200 & 300 & $\begin{array}{l}2-4 \text { days for short acting; up } \\
\text { to } 30 \text { days for long acting }\end{array}$ \\
\hline Benzodiazepines & 200 & $\begin{array}{l}\text { Oxazepam, diazepam, } \\
\text { other benzodiazepines }\end{array}$ & 200 & 300 & Up to 30 days \\
\hline Cocaine & 300 & Benzoylecgonine & 150 & 300 & $1-3$ days \\
\hline Codeine & 300 & Codeine, morphine & $300 ; 300$ & 2,$000 ; 300$ & 1-3 days \\
\hline Heroin & 300 & $\begin{array}{l}\text { Morphine, } \\
\text { 6-acetylmorphine }\end{array}$ & $300 ; 10$ & 2,$000 ; 300$ & 1-3 days \\
\hline Marijuana & $100 ; 50 ; 20$ & Tetrahydrocannabinol & 15 & 50 & $\begin{array}{l}1-3 \text { days for casual use; up to } \\
30 \text { days for chronic use }\end{array}$ \\
\hline Methadone & 300 & Methadone & 300 & 300 & 2-4 days \\
\hline Methamphetamine & 1000 & $\begin{array}{l}\text { Methamphetamine, } \\
\text { amphetamine }\end{array}$ & $500 ; 200$ & $1 ; 000 ; 50$ & 2-4 days \\
\hline Phencyclidine & 25 & Phencyclidine & 25 & 25 & $\begin{array}{l}2-7 \text { days for casual use; up to } \\
30 \text { days for chronic use }\end{array}$ \\
\hline
\end{tabular}


a custom panel is not available, multiple tests may have to be performed as rapid drug screening.

Cross-reactants with cannabinoids include Orudis KT, Aleve, Sustiva, Protonix, Marinol, ibuprofen, promethazine, and riboflavin. Opioid cross-reactivity includes poppy seeds, chlorpromazine, rifampin, dextromethorphan, and quinine. Cross-reactants to amphetamines include ephedrine, methylphenidate, pseudoephedrine, trazodone, desipramine, bupropion, fenfluramine, propranolol, labetalol, mexiletine, selegiline, tyramine, amantadine, ranitidine, phenylephrine, and Vicks Vapor Spray. PCP cross-reactants include chlorpromazine, thioridazine, dextromethorphan, diphenhydramine (Benadryl), and venlafaxine (Effexor). Benzodiazepine cross-reactants include oxaprozin (Daypro) and sertraline (Zoloft) and some herbal agents, while opioid cross-reactants include ofloxacin (Floxin), papaverine, and rifampin, as well as the oft-described poppy seeds. ETOH crossreactants sometimes include asthma inhalers. Since false-negatives and false-positives are possible, when questions arise, prior to taking any actions, a confirmatory test or no threshold test must be performed in the laboratory.

Urine is sometimes adulterated. Collected within 4 minutes, the temperature range should be between $90^{\circ}$ and $100^{\circ} \mathrm{F}$. The $\mathrm{pH}$ should be between 4.5 and 8 , and creatinine norm is $20 \mathrm{mg} / \mathrm{dl}$ and up. Dilute urine creatinine is $<20 \mathrm{mg} / \mathrm{dl}$ and adulterated urine is $<5$ $\mathrm{mg} / \mathrm{dl}$. Urine testing has difficulty identifying LSD, hallucinogens, inhalants, and anabolic steroids. A new emerging therapy for fibromyalgia, flunitrazepam (Rohypnol), is the "date-rape" drug that is utilized sometimes for sleep; it may show up on urine screening as a benzodiazepine. Urine can be adulterated with glutaraldehyde detergent, potassium nitrate acid, and Pyridium chlorochromate, which are readily available over the internet.

Physicians may establish zero or low tolerance, but this should be discussed with the patient on the initial visit, and should be part of the written clinic policy. This may include referral to an addictionologist or psychologist, or may result in the refusal to prescribe opioids. However, it usually does not warrant dismissal of the patient. The practice limits for presence of cocaine and marijuana may range from only one positive screen (zero tolerance) to 3 positive screens and appropriate action later. Improper use of prescription drugs and doctor shopping should be dealt in the same manner.

\subsection{Periodic Review and Monitoring}

\subsubsection{Periodic Review}

Periodic reviews should assess the medical diagnosis, psychological diagnosis, informed consent, treatment agreement, appropriate opioid therapy with or without adjuvant medications or with or without interventional techniques, pre- and post-intervention assessment of pain level, and function and reassessment of pain score and level of function.

Regular assessment of the patient along with periodic review of the diagnosis is extremely important. Routine assessment of the " 4 As" (analgesia, activity, aberrant behavior and adverse effects) will help to direct therapy and support pharmacologic actions taken (PASSIK reference add here).

Further assessment should be performed by periodic monitoring, pill counts, and UDT (see below).

\subsubsection{Periodic Monitoring}

At reasonable intervals depending on specific circumstances of a given patient, the physician should review the course of treatment and any new information about the etiology of the pain. Continuation or modification of therapy should depend on the physician's evaluation of progress towards the stated treatment goals, such as a reduction in a patient's pain scores and improved physical and/or psychosocial function (i.e., ability to work, utilization of healthcare resources, activities of daily living, and quality of social life). If treatment goals are not being achieved despite medication adjustments, the physician should reevaluate the appropriateness of continued treatment with the current medications. The physician should monitor patient compliance in medication usage and related treatment plans.

Some physicians have long embraced long-term opioid therapy, sometimes naïve of the consequences. Even the term pseudoaddiction involved only one case and one patient, and from there evolved into the philosophy of pseudoaddiction which took on its own meaning: "I think, therefore it is." Patients are becoming more demanding and the question is raised whether the detection of aberrant use is contradictory to the physician's goal, which is developing a sacred relationship.

\subsubsection{Prescription Drug Monitoring}

Prescription drug monitoring programs collect information to assist state law enforcement and regulatory agents in identifying and investigating illegal practices related to controlled substances. However, some of the existing prescription programs and the 
recently passed NASPER should also assist physicians and pharmacists in identifying controlled substance abuse. The purpose of NASPER is to ensure access to care, delegate the appropriate use of opioids to those in the most need, and identify potential abusers that misuse, divert, or doctor shop.

\subsubsection{Periodic Education}

Drug education for the physicians, providers, and patients is crucial. While it appears that certain medications have revolutionized the treatment of chronic pain in the United States, physicians must balance the medical need with the possibility of abuse and diversion, as well as the necessity to comply with the state and federal regulations. It is obvious that healthcare practitioners are not only expected to prescribe medications when there is medical need and document appropriately, but also they are expected to prevent illegal diversion and identify drug abuse. Consequently, education is a critical component of any program to control the diversion of prescription drugs.

\subsubsection{Pill Counts}

Random pill counts, along with UDT and prescription monitoring, would greatly reduce controlled substance abuse. Pill counts are essential in patients with suspicion of abuse. However, these can also be performed randomly on high-risk patients.

A pill count is performed by notifying the patient a day before or on the day of the appointment of the patient, requesting the patient to bring with them their unused pills. The inability to provide pills or providing a reduced number will indicate use beyond the prescription. Pill counts above the expected ranges would indicate inappropriate low intake (suggesting that the medications are being over-prescribed). Recently, it has been reported that some unsuspected elderly patients may be selling controlled substances to supplement their income.

\subsection{Principles of Opioid Usage}

\subsection{Introduction}

In interventional pain management, patients may receive not only opioid analgesics, but also other controlled or noncontrolled drugs. Further, patients may be receiving controlled substances as an adjunct to interventional techniques, as well as to manage comorbid psychiatric and psychological disorders. Thus, the effectiveness studies published thus far may not apply in the majority of interventional pain management patients. Indeed, in an interventional pain practice, controlled substances may be prescribed at lower doses, particularly opioid analgesics, in conjunction with interventional techniques. It has also been shown that interventional techniques reduce psychological distress and improve functional status (307-330). More likely than not, the requirement for opioids and adjuvant drugs may be reduced or at least become stable. Hence, interventional pain physicians probably should not compare patients in their settings undergoing interventional techniques with others receiving drug therapy as mainstay. Monotherapy, particularly with opioids, may be appropriate for only a small subgroup of those with chronic pain.

The concept of "universal precautions," first seen in medicine with the explosion of HIV and hepatitis tainted blood, was introduced to counter the misconception that a provider would be able to predict "by looking" who might have a communicable bloodborne disease. This led to the use of "precautions" (gloves, etc.) for all patients, regardless of their age or socieoeconomic class. A rational approach to the treatment of chronic pain with opioids has been described using a pain and addiction continuum and a substance use assessment in a pain patient leading to the implementation of "universal precautions" in pain medicine (331).

\subsection{Recommendation}

Based on the grading recommendations provided by Guyatt et al (37) and illustrated in Table 2, the recommendation is $2 \mathrm{~A}$ - weak recommendation, high-quality evidence: with benefits closely balanced with risks and burden; derived from RCTs without important limitations or overwhelming evidence from observational studies, with the implication that with a weak recommendation, best action may differ depending on circumstances or patients' or societal values.

\subsection{Basic Philosophy}

Principles for prescribing opioids must require a comprehensive evaluation (mandatory physical and optional psychological), appropriate documentation at regular intervals to assess the efficacy of therapy, with specific evaluation of the impact on functional status, degree of pain relief, identification and treatment of undesirable side effects, and monitoring for abuse behaviors. In addition, there must be adherence to a controlled substance agreement and with 
regulatory guidelines promulgated by various agencies. Fig. 6 shows an algorithmic approach to patient evaluation and management. Table 19 shows an algorithmic approach for chronic opioid therapy.

\subsection{Evaluation}

Appropriate history, physical examination, and medical decision-making based on the initial evaluation of a patient's presenting symptoms are essential. The guidelines of the Centers for Medicare and Medicaid Services (CMS) provide various criteria for 5 levels of evaluation and management services (E\&M) (332-335), with 3 crucial components: history, physical examination, and medical decision-making. Other components include counseling, coordination of care, nature of presenting problem, and time required for face-to-face evaluation. While there are numerous techniques to evaluate a chronic pain patient, which vary from physician to physician, institution to institution, and textbook to textbook, following the guidelines established by CMS will assist a physician in performing a comprehensive and complete evaluation complying with regulations.

Some of the aspects specific in controlled substance abuse and chronic pain include evaluation of the effect of pain on physical and psychological function, such as activities of daily living $(336,337)$.

\subsubsection{Diagnostic and Therapeutic Injections}

Diagnostic interventional techniques will assist in making the proper diagnosis by following an algorithmic approach (338-345). It has been shown that in approximately $70 \%$ to $85 \%$ of the patients with spinal pain an accurate diagnosis may not be provided in spite of the available history, physical examination, EMG nerve conduction studies, and radiological evaluation. With precise diagnostic interventional

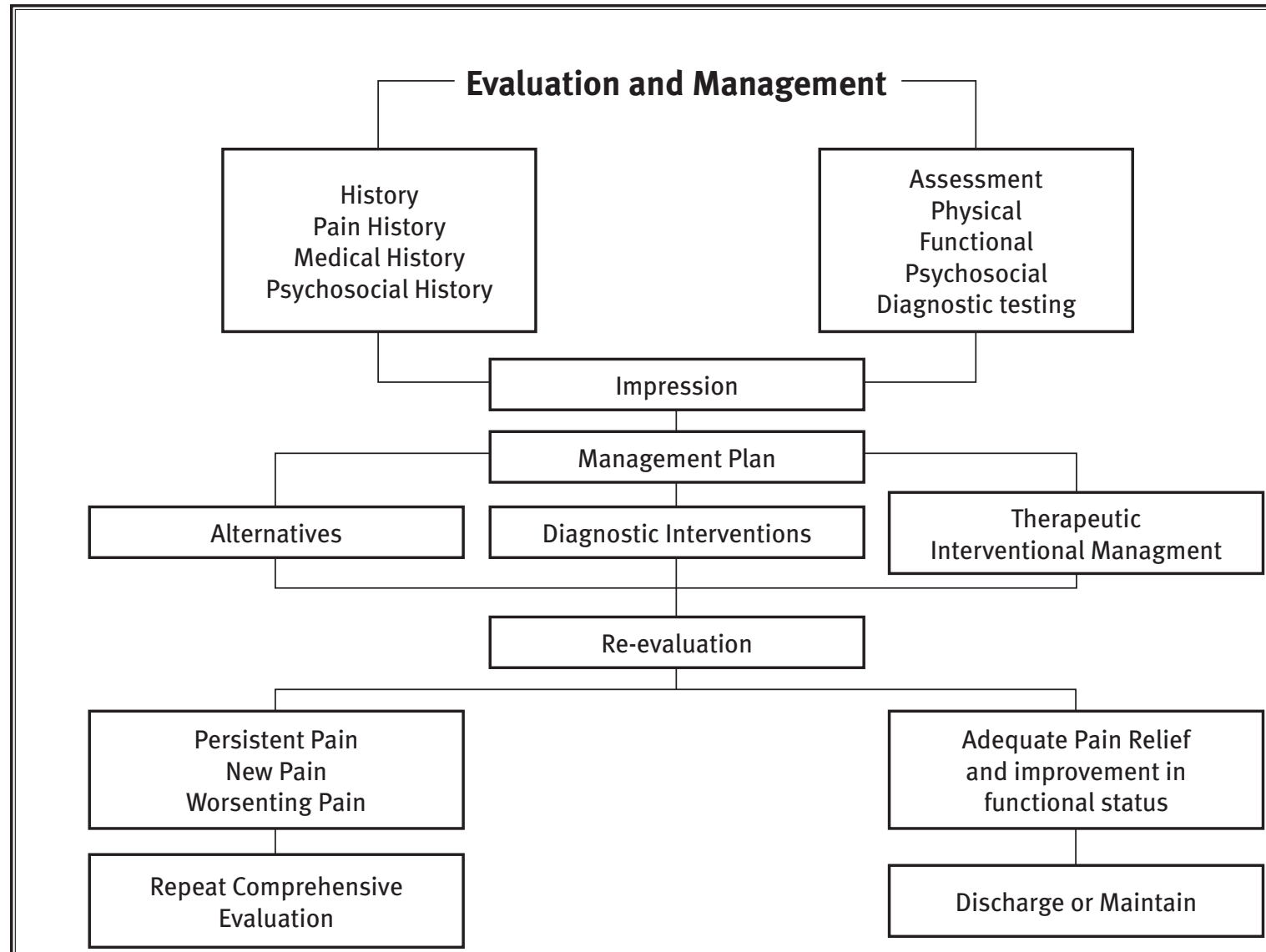

Fig. 6. Suggested algorithm for comprehensive evaluation and management of chronic pain. 
techniques, the chances of correct diagnosis may be improved substantially, and proper treatment may be offered (346-350).

Therapeutic interventional techniques also may be used in a monotherapeutic way rather than using opioids for pain management and functional improvement. The effectiveness of various interventional techniques has been evaluated in systematic reviews (307-330).

A written treatment plan should document objectives that will be used to evaluate treatment success, including pain relief and improved physical and psychosocial function, and should indicate if additional diagnostic tests, consultations, or treatments are planned. After starting treatment, the physician should adjust with care the drug therapy to the individual medical needs of each patient. In the continuum of treatment, other modalities, including interventional techniques, rehabilitation, and psychological therapy may be necessary depending on the etiology of the pain and the extent to which pain is associated with physical, functional, and psychosocial impairment.

\subsubsection{Consultation}

Physicians should be willing to refer a patient as clinically indicated for additional evaluation to achieve treatment objectives. Special attention should be given to those patients who are at risk of misusing their medications and those whose living arrangements create a risk for medication misuse or diversion. The management of patients with a history of substance abuse or with a coexisting psychiatric disorder may require extra care, monitoring, documentation, and consultation with, or referral to, an addictionologist. The lack of well-trained psychologists and psychiatrists in many regions of the country may make this referral difficult to obtain. Likewise in many locations there are no clinically trained addiction specialists with whom to collaborate. 8.4.3 Informed Consent and Controlled Substance Agreement

At the initial visit, the physician should discuss the risks and benefits of the use of controlled substances with the patient or surrogate, including the risk of tolerance and drug dependence. It is advisable to employ the use of a written agreement between physician and patient outlining patient responsibilities. Agreements are helpful, specifically if the patient is determined to be at high risk for medication abuse or have a history of substance abuse. Possible items of a controlled substance agreement between a physician and patient include:

1. One prescribing doctor and one designated pharmacy.
Table 19. Ten-step process: An algorithmic approach for longterm opioid therapy in chronic pain.

\begin{tabular}{|c|c|}
\hline STEP I & Comprehensive initial evaluation \\
\hline STEP II & $\begin{array}{l}\text { Establish diagnosis } \\
\text { - X-rays, MRI, CT, neuro-physiologic studies } \\
\text { - Psychological evaluation } \\
\text { - Precision diagnostic interventions }\end{array}$ \\
\hline STEP III & $\begin{array}{l}\text { Establish medical necessity (lack of progress or as } \\
\text { supplemental therapy) } \\
\text { - Physical diagnosis } \\
\text { Therapeutic interventional pain management } \\
\text { Physical modalities } \\
\text { Behavior therapy }\end{array}$ \\
\hline STEP IV & $\begin{array}{l}\text { Assess risk-benefit ratio } \\
\text { Treatment is beneficial }\end{array}$ \\
\hline STEP V & Establish treatment goals \\
\hline STEP VI & Obtain informed consent and agreement \\
\hline STEP VII & $\begin{array}{l}\text { Initial dose adjustment phase (up to 8-12 weeks) } \\
\text { Start low dose } \\
\text { Utilize opioids, NSAID's and adjuvants } \\
\text { Discontinue } \\
\text { - Lack of analgesia } \\
\text { - Side effects } \\
\text { - Lack of functional improvement }\end{array}$ \\
\hline STEP VIII & $\begin{array}{l}\text { Stable phase (stable - moderate doses) } \\
\text { - Monthly refills } \\
\text { - Assess for four A's } \\
\text { - Activity } \\
\text { - Aberrant behavior } \\
\text { - Adverse effect } \\
\text { - Manage side effects }\end{array}$ \\
\hline STEP IX & $\begin{array}{l}\text { Adherence monitoring } \\
\text { - Prescription monitoring programs } \\
\text { - Random drug screens } \\
\text { - Pill counts }\end{array}$ \\
\hline STEP X & $\begin{array}{l}\text { Outcomes } \\
\text { - Successful - continue } \\
\text { - Stable doses } \\
\text { - Analgesia, activity } \\
\text { - No abuse, side effects } \\
\text { - Failed - discontinue } \\
\text { - Dose escalation } \\
\text { - No analgesia } \\
\text { - No activity } \\
\text { - Abuse } \\
\text { - Side effects } \\
\text { - Non-compliance }\end{array}$ \\
\hline
\end{tabular}

2. Urine/serum drug screening when requested.

3. No early refills and no medications called in.

4. If medications are lost or stolen, then a police report could be required before considering additional prescriptions. 
The reasons for which opioid drug therapy may be discontinued, such as violation of a documented doctor/patient agreement, should be delineated. Ad- ditional items to be included in an agreement are listed in Table 20.

Table 20. Sample Controlled Substance Agreement

We are committed to doing all we can to treat your chronic pain condition. In some cases, controlled substances are used as a therapeutic option in the management of chronic pain and related anxiety and depression, which is strictly regulated by both state and federal agencies. This agreement is a tool to protect both you and the physician by establishing guidelines, within the laws, for proper controlled substance use. The words "we" and "our" refer to the facility and the words "I", "you", "your", "me", or "my" refer to you, the patient.

1. i. I understand that chronic opioid therapy has been associated with not only addiction and abuse, but also multiple medical problems including the suppression of endocrine function resulting in low hormonal levels in men and women which may affect mood, stamina, sexual desire, and physical and sexual performance.

ii. For female patients, if I plan to become pregnant or believe that I have become pregnant while taking this medication, I am aware that, should I carry the baby to delivery while taking these medications; the baby will be physically dependent upon opioids. I will immediately call my obstetrician and this office to inform them of my pregnancy. I am also aware that opioids may cause a birth defect, even though it is extremely rare.

iii. I have been informed that long-term and/or high doses of pain medications may also cause increased levels of pain known as opioid induced hyperalgesia (pain medicine causing more pain) where simple touch will be predicted as pain and pain gradually increases in intensity and also the location with hurting all over the body. I understand that opioid-induced hyperalgesia is a normal, expected result of using these medicines for a long period of time. This is only treated with addition of non-steroidal anti-inflammatory drugs such as Advil, Ibuprofen, etc., or by reducing or stopping opioids.

iv. I understand that physical dependence is not the same as addiction. I am aware physical dependence means that if my pain medicine use is markedly decreased, stopped, or reversed by some of the agents mentioned above, I will experience a withdrawal syndrome. This means I may have any or all of the following: runny nose, yawning, large pupils, goose bumps, abdominal pain and cramping, diarrhea, irritability, aches throughout my body and a flu-like feeling. I am aware that opioid withdrawal is uncomfortable, but not life threatening.

v. I am aware that tolerance to analgesia means that I may require more medicine to get the same amount of pain relief. I am aware that tolerance to analgesia does not seem to be a big problem for most patients with chronic pain; however, it has been seen and may occur to me. If it occurs, increasing doses may not always help and may cause unacceptable side effects. Tolerance or failure to respond well to opioids may cause my doctor to choose another form of treatment, reduce the dose, or stop it.

2. i. All controlled substances must come from the physician whose signature appears below or during his/her absence, by the covering physician, unless specific authorization is obtained for an exception.

ii. I understand that I must tell the physician whose signature appears below or during his/her absence, the covering physician, all drugs that I am taking, have purchased, or have obtained, even over-the-counter medications. Failure to do so may result in drug interactions or overdoses that could result in harm to me, including death.

iii. I will not seek prescriptions for controlled substances from any other physician, health care provider, or dentist. I understand it is unlawful to be prescribed the same controlled medication by more than one physician at a time without each physician's knowledge.

iv. I also understand that it is unlawful to obtain or to attempt to obtain a prescription for a controlled substance by knowingly misrepresenting facts to a physician or his/her staff or knowingly withholding facts from a physician or his/her staff (including failure to inform the physician or his/her staff of all controlled substances that I have been prescribed). 
Table 20 (continued). Sample Controlled Substance Agreement

3. All controlled substances must be obtained at the same pharmacy where possible. Should the need arise to change pharmacies, our office must be informed. The pharmacy that you have selected is:

Phone:

4. i. You may not share, sell, or otherwise permit others, including your spouse or family members, to have access to any controlled substances that you have been prescribed.

ii. Early refills will not be given. Renewals are based upon keeping scheduled appointments. Please do not make excessive phone calls for prescriptions or early refills and do not phone for refills after hours or on weekends.

5. Unannounced pill counts, random urine or serum, or planned drug screening may be requested from you and your cooperation is required. Presence of unauthorized substances in urine or serum toxicology screens may result in your discharge from the facility and its physicians and staff.

6. I will not consume excessive amounts of alcohol in conjunction with controlled substances. I will not use, purchase, or otherwise obtain any other legal drugs except as specifically authorized by the physician whose signature appears below or during his/her absence, by the covering physician, as set forth in Section 2 above. I will not use, purchase, or otherwise obtain any illegal drugs, including marijuana, cocaine, etc. I understand that driving while under the influence of any substance, including a prescribed controlled substance or any combination of substances (e.g., alcohol and prescription drugs), which impairs my driving ability, may result in DUI charges.

7. Medications or written prescriptions may not be replaced if they are lost, stolen, get wet, are destroyed, left on an airplane, etc. If your medication has been stolen, it will not be replaced unless explicit proof is provided with direct evidence from authorities. A report narrating what you told the authorities is not enough.

8. In the event you are arrested or incarcerated related to legal or illegal drugs (including alcohol), refills on controlled substances will not be given.

9. I understand that failure to adhere to these policies may result in cessation of therapy with controlled substances prescribed by this physician and other physicians at the facility and that law enforcement officials may be contacted.

10. I also understand that the prescribing physician has permission to discuss all diagnostic and treatment details, including medications, with dispensing pharmacists, other professionals who provide your health care, or appropriate drug and law enforcement agencies for the purpose of maintaining accountability.

11. I affirm that I have full right and power to sign and to be bound by this agreement, that I have read it, and understand and accept all of its terms. A copy of this document has been given to me.

Patient's full name

Patient's signature

Date

Physician's signature

Date 


\subsection{Documentation and Medical Records}

The physician should keep accurate and complete medical records, which include all aspects of interventional pain management and medical care. These comprise, but are not limited to:

- The medical history and physical examination

- Diagnostic, therapeutic, and laboratory results

- Evaluations and consultations

- Treatment objectives

- Discussion of risks, benefits, and limitations of treatments

- Details of different treatments, medications, including date, type, dosage, and quantity prescribed

- Instructions to the patient

- Periodic reviews of outcomes, including documentation of functional status, preferably using validated tools

Records should remain current and be maintained in an accessible manner and readily available for review, not only for the physician and other members of the practice, but also for authorities.

To be in compliance with controlled substance laws and regulations required to prescribe, dispense, or administer controlled substances, the physician must have an active license in the state and comply with applicable federal and state regulations. Various boards have published regulations and recommendations for prescribing controlled substances. Physicians are advised to refer to those regulations for their respective state. Physicians should not prescribe scheduled drugs for themselves or immediate family except in emergency situations.

The following criteria should be considered carefully in providing controlled substances:

1. Complete initial evaluation, including history and physical examination

2. Psychological evaluation

3. Physiological and functional assessment, as necessary and feasible

4. Definition of indications and medical necessity:

- Pain of moderate-to-severe degree

- Suspected organic problem

- Documentation of failure to respond to noncontrolled substances, adjuvant agents, physical therapy, and interventional techniques

- For patients with interventional techniques as primary modality, controlled substance drugs may be used as a second line treatment.

- For nonopioid controlled substances, appropriate documentation of psychological disorders should be maintained.

- Continued opioid prescription requires monitoring of "the $4 \mathrm{As}$ ":

- Analgesia

- Activity

- Aberrant behavior

- Adverse effect

5. The use of the lowest possible dose to provide adequate analgesia with minimum side effects should be the goal of opioid therapy.

6. In general, do not combine opioids with sedativehypnotics, benzodiazepines, or barbiturates for chronic, non-cancer pain unless there is a specific medical indication for the combination.

7. Adherence to the controlled substance agreement with patients understanding the risks and benefits of controlled substances and the policy and regulations of the practitioner, including controlled substances being prescribed by only one practitioner and being obtained from only one pharmacy.

8. Monitoring for drug abuse or diversion should be routine and if confirmed, referral to rehabilitation centers may be made, with termination of prescriptions of controlled substances.

9. Use caution when prescribing acetaminophencontaining opioids, especially given the ubiquitousness of acetaminophen in over-the-counter medications. Short-term use ( $<10$ days) should be less than 4,000 mg/day, while chronic use should probably be limited to $2,500 \mathrm{mg} /$ day.

While there are no universally accepted tools to assess opioid responsiveness, it is important to use a tool that monitors both function and pain relief.

Although opioids may be useful for the treatment of chronic pain, aberrant behavior and/or no improvement in function and pain after an adequate trial of opioids should trigger a consideration to discontinue the opioids, tapered over a several week period to avoid withdrawal symptoms. Evidence of diversion or illegal use warrants an immediate discontinuation of the medication. Clonidine po or transdermal $0.1 \mathrm{mg}$ can be offered to counteract the majority of withdrawal symptoms. 


\subsection{Key Points}

1. These opioid guidelines for the treatment of chronic non-cancer pain were developed to improve the quality and appropriateness of care, improve patient access, improve patient quality of life, improve efficiency and effectiveness, and achieve cost containment by improving the costbenefit ratio.

2. Opioids are extensively used in managing chronic pain.

3. There is significant evidence of opioid abuse in conjunction with or without illicit drugs.

4. Abuse terminology is variable. This document attempts to standardize and provide a common sense definition.

5. Opioid pharmacology is variable and essential to understand for proper management of patients.

6. Among the rules of opioid administration, comprehensive evaluation and diagnostic assessment is crucial, including diagnosis by interventional techniques.

7. Establishing goals of treatment and using a controlled substance agreement are essential in the practice of pain management with opioids.

8. Periodic review of the patient on opioids is essen- tial, using appropriate adjustments, with routine assessment of analgesia, activity, aberrant behavior, and adverse effects.

9. Documentation, keeping accurate and complete medical records with all the essential elements to provide proper patient care and also meet regulatory and legal requirements, is essential.

10. The rationalization and importance of these guidelines lies in the fact that most available evidence documents a wide degree of variance in the prescribing patterns of opioids for chronic pain. The strength of available evidence in the use of opioids for chronic non-cancer pain is weak.

\section{Acknowledgements}

The authors wish to thank Leon McCallum, Department of Anesthesia, University of Florida, for his invaluable assistance in obtaining the articles for review and Tonie M. Hatton and Diane E. Neihoff, Transcriptionists; Vidyasagar Pampati, MSc, Statistician; Sekhar Edem, Research Assistant; Victoria Caldwell, Graphic Designer; and Ray Lane, Director of Education and Public Relations, for their assistance in the preparation of this manuscript.

\section{Author Affiliations}

Dr. Trescot is Director, Pain Fellowship, University of Florida, Gainesville, FL; and Director Malcolm Randal VA, Gainesville, FL

Dr. Helm II is with Pacific Coast Pain Management Center, Laguna Hills, CA

Dr. Hansen is Medical Director, The Pain Relief Centers, PA, Conover, NC

Dr. Benyamin is President and Medical Director, Millennium Pain Center, Bloomington, IL; and Clinical Assistant Professor, College of Medicine, University of Illinois, Urbana-

Champaign, IL

Dr. Glaser is with Pain Specialists of Greater Chicago, IL

Dr. Adlaka, MD is with Pain Control Associates, Munster IN
Dr. Patel is a Pain Fellow, University of Florida, Malcolm Randall VA, Gainesville, FL

Dr. Manchikanti is Chief Executive Officer, ASIPP; Medical Director, Pain Management Center of Paducah , Paducah, KY; and Associate Clinical Professor, Anesthesiology and Perioperative Medicine, University of Louisville, Kentucky

Dr. Datta is Director, Vanderbilt University, Interventional Pain Program, and Associate Professor, Dept. of Anesthesiology, Vanderbilt University Medical Center, Nashville TN

Dr. Sehgal is Associate Professor of Rehabilitation Medicine, Medical Director of Interventional Pain Program, University of Wisconsin School of Medicine and Public Health, Dept. of Orthopedics and Rehabilitation, Madison, WI
Dr. Colson is Assistant Professor of Anesthesiology, Department of Anesthesiology, Pain Medicine Service, West Virginia University Hospitals, Morgantown, WV

Dr. Jordan is with Coastal Interventional Pain Associates, Myrtle Beach, SC

Dr. Lee, Jr. is Director of Pain Center at Affinity Health Group, Tifton, GA 


\section{References}

1. Trescot AT, Boswell MV, Alturi SL, Hansen HC, Deer TR, Abdi S, Jasper JF, Singh $V$, Jordan AE, Johnson BW, Cicala RS, Dunbar EE, Helm S, Varley KG, Suchdev PK, Swicegood JR, Calodney AK, Ogoke BA, Minore WS, Manchikanti L. Opioid guidelines in the management of chronic non-cancer pain. Pain Physician 2006; 9:1-40.

2. Manchikanti L. National drug control policy and prescription drug abuse: Facts and fallacies. Pain Physician 2007; 10:399-424.

3. Manchikanti L, Whitfield E, Pallone F. Evolution of the National All Schedules Prescription Electronic Reporting Act (NASPER): A public law for balancing treatment of pain and drug abuse and diversion. Pain Physician 2005; 8:335347.

4. Manchikanti L. Prescription drug abuse: What is being done to address this new drug epidemic? Testimony before the Subcommittee on Criminal Justice, Drug Policy and Human Resources. Pain Physician 2006; 9:287-321.

5. Manchikanti L, Singh A. Therapeutic opioids: A ten-year perspective on the complexities and complications of the escalating use, abuse, and nonmedical use of opioids. Pain Physician 2008; 11: S63-S89.

6. Ballantyne JC. Opioid analgesia: Perspectives on right use and utility. Pain Physician 2007; 10:479-491.

7. Højsted J, Sjøgren P. Addiction to opioids in chronic pain patients: A literature review. Eur J Pain 2007; 11:490518.

8. Benyamin R, Trescot A, Datta S, Buenaventura R, Adlaka R, Sehgal N, Glaser SE, Vallejo R. Opioid complications and side effects. Pain Physician 2008; 11:S105-S120.

9. Noble M, Tregear SJ, Treadwell JR, Schoelles K. Long-term opioid therapy for chronic noncancer pain: A systematic review and meta-analysis of efficacy and safety. I Pain Symptom Manage 2008; 35:214-228.

10. Martell BA, O'Connor PG, Kerns RD, Beck WC, Morales KH, Kosten TR, Fiellen DA. Systematic review: Opioid treatment for chronic back pain: Prevalence, efficacy, and association with addiction. Ann Intern Med 2007; 146:116-127.

11. Chou R, Clark E, Helfand M. Comparative efficacy and safety of long-acting oral opioids for chronic non-cancer pain: A systematic review. J Pain Symp- tom Manage 2003; 26:1026-1048.

12. Kalso E, Edwards JE, Moore RA, McQuay HJ. Opioids in chronic non-cancer pain: Systematic review of efficacy and safety. Pain 2004; 112:372-380.

13. Furlan AD, Sandoval JA, Mailis-Gagnon A, Tunks E. Opioids for chronic noncancer pain: A meta-analysis of effectiveness and side effects. Can Med Assoc J 2006; 174:1589-1594.

14. Ballantyne JC, Mao J. Opioid therapy for chronic pain. N Engl J Med 2003; 349:1943-1953.

15. Eisenberg E, McNicol E, Carr DB. Opioids for neuropathic pain. Cochrane Database of Systematic Reviews 2006, Issue 3. Art. No.: CDoo6146. DOI: 10.1002/14651858.CDoo6146.

16. Deshpande A, Furlan A, Mailis-Gagnon A, Atlas S, Turk D. Opioids for chronic low-back pain. Cochrane Database of Systematic Reviews 2007, Issue 3. Art. No.: CDoo4959.DOI:10.1002/14651858. CDoo4959.pub3.

17. Cepeda MS, Camargo F, Zea C, Valencia L. Tramadol for osteoarthritis: A systematic review and metaanalysis. I Rheumatol 2007; 34:543-555.

18. Sandoval JA, Furlan AD, Mailis-Gagnon AM. Oral methadone for chronic noncancer pain: A systemic literature review of reasons for administration, prescription patterns, effectiveness, and side effects. Clin J Pain 2005; 21:503512.

19. Trescot AM, Glaser S, Hansen H, Benyamin R, Patel S, Manchikanti L. Effectiveness of opioids in the treatment of chronic non-cancer pain. Pain Physician 2008; 11:S181-S200.

20. Manchikanti L, Abdi S, Lucas LF. Evidence synthesis and development of guidelines in interventional pain management. Pain Physician 2005; 8:7386.

21. Manchikanti L, Heavner J, Racz GB, Mekhail NA, Schultz DM, Hansen HC, Singh V. Methods for evidence synthesis in interventional pain management. Pain Physician 2003; 6:89-111.

22. Manchikanti L, Boswell MV, Giordano J. Evidence-based interventional pain management: Principles, problems, potential and applications. Pain Physician 2007; 10:329-356.

23. Manchikanti L. Evidence-based medicine, systematic reviews, and guidelines in interventional pain management: Part 1: Introduction and general considerations. Pain Physician 2008; 11:161-186.

24. West S, King V, Carey TS, Lohr KN, McKoy N, Sutton SF, Lux L. Systems to Rate the Strength of Scientific Evidence. Evidence Report/Technology Assessment No. 47. AHRQ Publication No. 02E016. Rockville, MD: Agency for Healthcare Research and Quality, 2002. www. thecre.com/pdf/ahrq-system-strength. pdf

25. Atkins $D$, Best $D$, Briss PA, Eccles $M$, Falck-Ytter $Y$, Flottorp S, Guyatt GH, Harbour RT, Haugh MC, Henry D, Hill S, Jaeschke R, Leng G, Liberati A, Magrini N, Mason J, Middleton P, Mrukowicz J, O'Connell D, Oxman AD, Phillips B, Schünemann HJ, Edejer TT, Varonen $\mathrm{H}$, Vist GE, Williams JW Jr, Zaza S; GRADE Working Group. www.ncbi. nlm.nih.gov/pubmed15205295?ordin alpos $=10 \&$ itool=EntrezSystem 2. PEntrez.Pubmed.Pubmed_ResultsPanel. Pubmed_RVDocSumGrading quality of evidence and strength of recommendations. BMJ 2004; 328:1490.

26. U.S. Preventive Services Task Force. Guide to Clinical Preventive Services, 2nd Ed. International Medical Publishing, Inc., Alexandria, VA, 1996.

27. Guyatt GH, Sackett DL, Sinclair JC, Hayward R, Cook DJ, Cook RJ. Users' guides to the medical literature. IX. A method for grading health care recommendations. Evidence-Based Medicine Working Group. JAMA 1995; 274:1800-1804.

28. Gray JAM. Evidence-Based Healthcare. Churchill Livingstone, London, 1997.

29. van Tulder MW, Koes BW, Bouter LM. Conservative treatment of acute and chronic nonspecific low back pain. A systematic review of randomized controlled trials of the most common interventions. Spine 1997; 22:2128-2156.

30. Bril V, Allenby K, Midroni G, O'Connor PW, Vajsar J. IGIV in neurology-evidence and recommendations. Can J Neurol Sci 1999; 26:139-152.

31. Shekelle PG, Woolf SH, Eccles M, Grimshaw J. Clinical guidelines: Developing guidelines. BMJ 1999; 318:593-596.

32. Ariens GA, van Mechelen W, Bongers PM, Bouter LM, van der Wal G. Physical risk factors for neck pain. Scand J Work Environ Health 2000; 26:7-19.

33. National Health and Medical Research Council (NHMRC). How to Use the Evidence: Assessment and Application of Scientific Evidence. NHMRC, Canberra, 
Australia, 2000.

34. NHS Research and Development Centre of Evidence-Based Medicine. Levels of Evidence. http://cebm.jr2.ox.ac.uk

35. Sackett DL, Straus SE, Richardson WS, Rosenberg W, Haynes RB. EvidenceBased Medicine: How to Practice and Teach EBM. Second Ed. Churchill Livingstone, Edinburgh, 2000.

36. Harris RP, Helfand M, Woolf SH, Lohr KN, Mulrow CD, Teutsch SM, Atkins D; Methods Work Group, Third U.S. Preventive Services Task Force. Current methods of the U.S. Preventive Services Task Force: A review of the process. Am J Prev Med 2001; 20:21-35.

37. Guyatt G, Gutterman D, Baumann MH, Addrizzo-Harris D, Hylek EM, Phillips B, Raskob G, Lewis SZ, Schünemann $\mathrm{H}$. Grading strength of recommendations and quality of evidence in clinical guidelines. Report from an American College of Chest Physicians task force. Chest 2006; 129:174-181.

38. Clarke M, Oxman AD, editors. Cochrane Reviewers Handbook 4.1.4 (updated October 2001). In: The Cochrane Library, Issue 4, 2001. Oxford: Update Software. Updated quarterly.

39. Boswell MV, Trescot AM, Datta S, Schultz DM, Hansen HC, Abdi S, Sehgal N, Shah RV, Singh V, Benyamin RM, Patel VB, Buenaventura RM, Colson JD, Cordner HJ, Epter RS, Jasper JF, Dunbar EE, Atluri SL, Bowman RC, Deer TR, Swicegood JR, Staats PS, Smith HS, Burton AW, Kloth DS, Giordano J, Manchikanti L. Interventional techniques: Evidencebased practice guidelines in the management of chronic spinal pain. Pain Physician 2007; 10:7-111.

40. Field MJ, Lohr KN (eds). Clinical Practice Guidelines: Directions for a New Program. National Academies Press, Washington, 1990.

41. Sackett D, Richardson WS, Roseberg W, Haynes RB. Evidence Based Medicine. Churchill Livingstone, Philadelphia, 1996.

42. Sackett DL, Rosenberg WM, Gray JAM, Haynes RB, Richardson WS. Evidence based medicine: What it is and what it isn't. BMJ 1996; 312: 71-72.

43. Manchikanti L, Singh V, Bakhit CE, Fellows B. Interventional techniques in the management of chronic pain. Part 1.0. Pain Physician 2000; 3:7-42.

44. Manchikanti L, Singh V, Kloth DS, Slipman CW, Jasper JF, Trescot AM, Varley KG, Atluri SL, Giron C, Curran MJ, Rivera JJ, Baha A, Bakhit CE, Reuter M. In- terventional techniques in the management of chronic pain: Part 2.o. Pain Physician 2001; 4:24-96.

45. Manchikanti L, Staats P, Singh V, Schultz DM, Vilims BD, Jasper JF, Kloth DS, Trescot AM, Hansen HC, Falasca TD, Racz GB, Deer T, Burton AW, Helm S, Lou L, Bakhit CE, Dunbar EE, Atluri SL, Calodney AK, Hassenbusch S, Feler CA. Evidence-based practice guidelines for interventional techniques in the management of chronic spinal pain. Pain Physician 2003; 6:3-80.

46. Boswell MV, Shah RV, Everett CR, Sehgal N, Mckenzie-Brown AM, Abdi S, Bowman RC, Deer TR, Datta S, Colson JD, Spillane WF, Smith HS, LucasLevin LF, Burton AW, Chopra P, Staats PS, Wasserman RA, Manchikanti L. Interventional techniques in the management of chronic spinal pain: Evidencebased practice guidelines. Pain Physician 2005; 8:1-47.

47. Atluri $S$, Boswell MV, Hansen $H C$, Trescot AM, Singh V, Jordan AE. Guidelines for the use of controlled substances in the management of chronic pain. Pain Physician 2003; 6:233-257.

48. Airaksinen O, Brox JI, Cedraschi C, Hildebrandt J, Klaber-Moffett J, Kovacs F, Mannion AF, Reis S, Staal JB, Ursin H, Zanoli G. Chapter 4: European guidelines for the management of chronic nonspecific low back pain. Eur Spine J 2006; 15:S192-S300.

49. Dennison PL. Official Disability Guideline,. 13th Ed. Work Loss Data Institute, 2008.

50. American College of Occupational and Environmental Medicine, Glass LS. Occupational Medicine Practice Guidelines: Evaluation and Management of Common Health Problems and Functional Recovery of Workers. 2nd Ed. Beverly Farms, OEM Press, 2004.

51. Roper Starch Worldwide for the American Academy of Pain Medicine, American Pain Society, and Janssen Pharmaceutica. Chronic Pain in America: Roadblocks to Relief, 1999.

52. Verhaak PF, Kerssens JJ, Dekker J, Sorbi MJ, Bensing JM. Prevalence of chronic benign pain disorder among adults: A review of the literature. Pain 1998; 77:231-239.

53. Blyth FM, March LM, Brnabic AJ, Jorm LR, Williamson M, Cousins MJ. Chronic pain in Australia: A prevalence study. Pain 2001; 89:127-134.

54. Gureje O, Von Korff M, Simon GE, Gater R. Persistent pain and well-being: $A$
World Health Organization study in primary care. JAMA 1998; 280:147-151.

55. Harstall C, Ospina M. How prevalent is chronic pain? Pain Clin Updat 2003; 11:1-4.

56. Breivik H, Collett B, Ventafridda V, Cohen R, Gallacher D. Survey of chronic pain in Europe: Prevalence, impact on daily life, and treatment. Eur J Pain 2006; 10:287-333.

57. Clark JD. Chronic pain prevalence and analgesic prescribing in a general medical population. J Pain Symptom Manage 2002; 23:131-137.

58. Bressler HB, Keyes WJ, Rochon PA, Badley $E$. The prevalence of low back pain in the elderly. A systemic review of the literature. Spine 1999; 24:1813-1819.

59. Lawrence RC, Helmick CG, Arnett FC. Estimates of the prevalence of arthritis and selected musculoskeletal disorders in the United States. Arthritis Rheum 1998; 41:778-799.

60. Mallen C, Peat G, Thomas E, Croft P. Severely disabling chronic pain in young adults: Prevalence from a populationbased postal survey in North Staffordshire. BMC Musculoskeletal Disords 2005;, 6:42.

61. Jacobs JM, Hammerman-Rozenberg R, Cohen A, Stessman J. Chronic back pain among the elderly: Prevalence, associations, and predictors. Spine 2006; 31: E203-E207.

62. Bernstein RM, Cozen H. Evaluation of back pain in children and adolescents. Am Fam Physician 2007; 76:16691676.

63. Lynch AM, Kashikar-Zuck S, Goldschneider KR, Jones BA. Psychosocial risks for disability in children with chronic back pain. J Pain 2006; 7:244-251.

64. Helmick CG, Felson DT, Lawrence RC, Gabriel S, Hirsch R, Kwoh CK, Liang MH, Kremers HM, Mayes MD, Merkel PA, Pillemer SR, Reveille JD, Stone JH; National Arthritis Data Workgroup. Estimates of the prevalence of arthritis and other rheumatic conditions in the United States. Part I. Arthritis Rheum 2008; 58:15-25.

65. Lawrence RC, Felson DT, Helmick CG, Arnold LM, Choi H, Deyo RA, Gabriel S, Hirsch R, Hochberg MC, Hunder GG, Jordan JM, Katz JN, Kremers HM, Wolfe F; National Arthritis Data Workgroup. Estimates of the prevalence of arthritis and other rheumatic conditions in the United States. Part II. Arthritis Rheum 2008; 58:26-35. 
66. Bouhassira D, Lantéri-Minet $M$, Attal $\mathrm{N}$, Laurent B, Touboul C. Prevalence of chronic pain with neuropathic characteristics in the general population. Pain 2007 (Epub ahead of print).

67. Smith BH, Torrance N, Bennett MI, Lee A. Health and quality of life associated with chronic pain of predominantly neuropathic origin in the community. Clin J Pain 2007; 23:143-149.

68. Torrance N, Smith BH, Bennett MI, Lee A. The epidemiology of chronic pain of predominantly neuropathic origin. Results from a general population survey. J Pain 2006; 7:281-289.

69. Taylor RS. Epidemiology of refractory neuropathic pain. Pain Practice 2006; 6:22-26.

70. Argoff CE, Cole BE, Fishbain DA, Irving GA. Diabetic peripheral neuropathic pain: Clinical and quality-of-life issues. Mayo Clin Proc 2006; 81:S3-S11.

71. Maguire MF, Ravenscroft A, Beggs D, Duffy JP. A questionnaire study investigating the prevalence of the neuropathic component of the neuropathic component of chronic pain after thoracic surgery. Eur I Cardiothorac Surg 2006; 29:800-805.

72. Dijkstra PU, Rietman JS, Geertzen JHB Phantom breast sensations and phantom breast pain: A 2-year prospective study and methodological analysis of literature. Eur J Pain 2007; 11:1:99-108.

73. Elliott AM, Smith BH, Hannaford PC Smith WC, Chambers WA. The course of chronic pain in the community: Results of a 4-year follow-up study. Pain 2002; 99:299-307.

74. Yeung SS, Genaidy A, Deddens J, Alhe$\operatorname{mood} A$, Leung PC. Prevalence of musculoskeletal symptoms in single and multiple body regions and effects of perceived risk of injury among manual handling workers. Spine 2002; 27:2166-2172.

75. Loney PL, Stratford PW. The prevalence of low back pain in adults: A methodological review of the literature. Phys Ther 1999; 79:384-396.

76. Enthoven P, Skargren E, Oberg B. Clinical course in patients seeking primary care for back or neck pain: A prospective 5-year follow-up of outcome and health care consumption with subgroup analysis. Spine 2004; 29:24582465.

77. Sjolie AN. Persistence and change in nonspecific low back pain among adolescents: A 3-year prospective study. Spine 2004; 29:2452-2457.
78. Brattberg G. Do pain problems in young school children persist into early adulthood? A 13-year follow-up. Eur J Pain 2004; 8:187-199.

79. Elders LA, Burdorf A. Prevalence, incidence, and recurrence of low back pain in scaffolders during a 3-year follow-up study. Spine 2004; 29:E101-E106.

8o. Hoving JL, de Vet HC, Twisk JW, Deville WL, van der Windt D, Koes BW, Bouter LM. Prognostic factors for neck pain in general practice. Pain 2004; 110:639645.

81. Smith BH, Elliott AM, Hannaford PC, Chambers WA, Smith WC. Factors related to the onset and persistence of chronic back pain in the community: Results from a general population follow-up study. Spine 2004; 29:10321040.

82. Côté P, Cassidy JD, Carroll LJ, Kristman $V$. The annual incidence and course of neck pain in the general population: $A$ population-based cohort study. Pain 2004; 112:267-273.

83. Carroll LJ, Hogg-Johnson S, Côté P, van der Velde G, Holm LW, Carragee EJ, Hurwitz EL, Peloso PM, Cassidy JD, Guzman J, Nordin M, Haldeman S; Bone and Joint Decade 2000-2010 Task Force on Neck Pain and Its Associated Disorders. Course and prognostic factors for neck pain in workers: Results of the Bone and Joint Decade 2000-2010 Task Force on Neck Pain and Its Associated Disorders. Spine 2008; 33:S93-S100.

84. Luo X, Pietrobon R, Sun SX, Liu GG, Hey L. Estimates and patterns of direct health care expenditures among individuals with back pain in the United States. Spine 2004; 29:79-86.

85. Dionne CE, Chenard M. Back-related functional limitations among fulltime homemakers: A comparison with women employed full-time outside the home. Spine 2004; 29:1375-1382.

86. Reyes-Gibby CC, Aday L, Cleeland C. Impact of pain on self-rated health in the community-dwelling older adults. Pain 2002; 95:75-82.

87. Leigh JP, Markowitz SB, Fahs M, Shin C, Landrigan PJ. Occupational injury and illness in the United States. Estimates of costs, morbidity, and mortality. Arch Intern Med 1997; 157:1557-1568.

88. Freedman VA, Martin LG, Schoeni RF. Recent trends in disability and functioning among older adults in the United States. JAMA 2002; 288:3137-3146.

89. Turner JA, Franklin G, Heagerty PJ, Wu
R, Egan K, Fulton-Kehoe D, Gluck JV, Wickizer TM. The association between pain and disability. Pain 2004; 112:307314.

90. Walker BF, Muller R, Grant WD. Low back pain in Australian adults: The economic burden. Asia Pac J Public Health 2003; 15:79-87.

91. Hogg-Johnson S, van der Velde G, Carroll LJ, Holm LW, Cassidy JD, Guzman J, Côté P, Haldeman S, Ammendolia C, Carragee E, Hurwitz E, Nordin M, Peloso P; Bone and Joint Decade 2000-2010 Task Force on Neck Pain and Its Associated Disorders. www.ncbi.nlm.nih.gov/ pubmed 18204398 ? ordinalpos $=6 \&$ ito ol=EntrezSystem2.PEntrez.Pubmed. Pubmed_ResultsPanel.Pubmed_RVDocSum. The burden and determinants of neck pain in the general population: results of the Bone and Joint Decade 2000-2010 Task Force on Neck Pain and Its Associated Disorders. Spine 2008; 33:S39-S51.

92. Martin BI, Deyo RA, Mirza SK, Turner JA, Comstock BA, Hollingworth W, Sullivan SD. Expenditures and health status among adults with back and neck problems. JAMA 2008; 299:656-664.

93. Côté P, van der Velde G, Cassidy D, Carroll LJ, Hogg-Johnson S, Holm LW, Carragee EJ, Haldeman S, Nordin M, Hurwitz EL, Guzman J, Peloso PM; Bone and Joint Decade 2000-2010 Task Force on Neck Pain and Its Associated Disorders. The burden and determinants of neck pain in workers: Results of the Bone and Joint Decade 2000-2010 Task Force on Neck Pain and Its Associated Disorders. Spine 2008; 33:S60-S74.

94. Hough J. Estimating the health care utilization costs associated with people with disabilities: Data from the 1996 Medical Expenditure Panel Survey (MEPS). Annual Meeting of the Association for Health Services Research, Los Angeles, California, 2000.

95. Bell G, Kidd D, North R. Cost-effectiveness analysis of spinal cord stimulation in treatment of failed back surgery syndrome. J Pain Symp Manage 1997; 13:286-295.

96. de Lissovoy G, Brown RE, Halpern M, Hassenbusch SJ, Ross E. Cost-effectiveness of long-term intrathecal morphine therapy for pain associated with failed back surgery syndrome. Clin Ther 1997; 19:96-112.

97. Turk DC. Clinical effectiveness and cost-effectiveness of treatments for patients with chronic pain. Clin J Pain 
2002; 18:355-365.

98. Stewart WF, Ricci JA, Chee E, Morganstein $\mathrm{D}$, Lipton $\mathrm{R}$. Lost productive time and cost due to common pain conditions in the U.S. workforce. JAMA 2003; 290:2443-2454.

99. Turk DC. When is a person with chronic pain a patient? American Pain Society Bulletin Spring 2005; 15. www.ampainsoc.org

100. Vallerand AH, Fouladbakhsh JM, Templin T. The use of complementary/alternative medicine therapies for the selftreatment of pain among residents of urban, suburban, and rural communities. Am J Public Health 2003; 93:923925.

101. Blyth FM, March LM, Cousins MJ. Chronic pain-related disability and use of analgesia and health services in a Sydney community. Med J Aust 2003; 179:8487.

102. Birse TM, Lander J. Prevalence of chronic pain. Can J Public Health 1998; 89:129-131.

103. Mathias SD, Kuppermann M, Liberman RF, Lipschutz RC, Steege JF. Chronic pelvic pain: Prevalence, health-related quality of life, and economic correlates. Obstet Gynecol 1996; 87:321-327.

104. Smith BH, Elliott AM, Chambers WA, Smith WC, Hannaford PC, Penny K. The impact of chronic pain in the community. Fam Pract 2001; 18:292-299.

105. Strine TW, Hootman JM, Chapman DP, Okoro CA, Balluz L. Health-related quality of life, health risk behaviors, and disability among adults with painrelated activity difficulty. Am J Public Health 2005; 95:2042-2048.

106. Andersson HI, Ejlertsson G, Leden I, Rosenberg C. Chronic pain in a geographically defined general population: Studies of differences in age, gender, social class, and pain localization. Clin J Pain 1993; 9:174-182.

107. Zhu K, Devine A, Dick IM, Prince RL. As sociation of back pain frequency with mortality, coronary heart events, mobility, and quality of life in elderly women. Spine 2007; 32:2012-2018.

108. Mossey JM, Gallagher RM, Tirumalasetti F. The effects of pain and depression on physical functioning in elderly residents of a continuing care retirement community. Pain Med 2000; 4:340350.

109. Meyer T, Cooper J, Raspe H. Disabling low back pain and depressive symptoms in the community-dwelling elderly: A prospective study. Spine 2007;
32:2380-2386.

110. Boerlage AA, van Dijk M, Stronks DL, de Wit R, van der Rijt CC. Pain prevalence and characteristics in three Dutch residential homes. Eur J Pain 2008 Feb 9 [Epub ahead of print].

111. Klinger L, Spaulding SJ, Polatajko HJ, MacKinnon JR, Miller L. Chronic pain in the elderly: Occupational adaptation as a means of coping with osteoarthritis of the hip and/or knee. Clin J Pain 1999; 15:275-283.

112. Rudy TE, Weiner DK, Lieber SJ, Slaboda J, Boston JR. The impact of chronic low back pain on older adults: A comparative study of patients and controls. Pain 2007; 131:293-301.

113. Von Korff M, Crane P, Lane M, Miglioretti DL, Simon G, Saunders K, Stang P, Brandenburg N, Kessler R. Chronic spinal pain and physical-mental comorbidity in the United States: Results from the national comorbidity survey replication. Pain 2005; 113:331-339.

114. Gureje O, Akinpelu AO, Uwakwe R, Udofia $\mathrm{O}$, Wakil A. Comorbidity and impact of chronic spinal pain in Nigeria. Spine 2007; 32:E495-E500.

115. Saunders K, Merikangas K, Low NC, Von Korff M, Kessler RC. Impact of comorbidity on headache-related disability. Neurology 2008; 70:538-547.

116. Kroenke K, Shen J, Oxman TE, Williams JW Jr, Dietrich AJ. Impact of pain on the outcomes of depression treatment: Results from the RESPECT trial. Pain 2008; 134:209-215.

117. Becker C, Brobert GP, Almqvist PM, Johansson S, Jick SS, Meier CR. http:// www.ncbi.nlm.nih.gov/pubmed 17986 274 ? ordinalpos $=3$ \&itool $=$ EntrezSyste m2.PEntrez.Pubmed.Pubmed_ResultsPanel.Pubmed_RVDocSumMigraine incidence, comorbidity and health resource utilization in the UK. Cephalalgia 2008; 28:57-64.

118. Ashina S, Lipton RB, Bigal ME. Treatment of comorbidities of chronic daily headache. Curr Treat Options Neurol 2008; 10:36-43.

119. White LA, Birnbaum HG, Kaltenboeck A, Tang J, Mallett D, Robinson RL. Employees with fibromyalgia: Medical comorbidity, healthcare costs, and work loss. J Occup Environ Med 2008; 50:1324.

120. Manchikanti L, Giordano J, Boswell MV, Fellows B, Manchukonda R, Pampati V. Psychological factors as predictors of opioid abuse and illicit drug use in chronic pain patients. J Opioid Manage
2007; 3:89-100.

121. Manchikanti L. Role of psychology in interventional pain management. Pain Physician 2002; 5:440-444.

122. Manchikanti L, Pampati V, Damron KS, Beyer CD, Barnhill RC. Evaluation of psychological status in chronic low back pain: Comparison with general population. Pain Physician 2002; 5:149-155.

123. Manchikanti L, Fellows B, Singh V. Understanding psychological aspects of chronic pain in interventional pain management. Pain Physician 2002; 5:57-82.

124. Manchikanti L, Fellows B, Pampati V, Damron KS, Beyer CD, Barnhill RC. Comparison of psychological status of chronic pain patients with general population. Pain Physician 2002; 5:40-48.

125. Rivera JJ, Singh V, Fellows B, Pampati V, Damron KS, McManus CD. Reliability of psychological evaluation in chronic pain in an interventional pain management setting. Pain Physician 2005; 8:375-383.

126. Rush AJ, Polatin P, Gatchel RJ. Depression and chronic low back pain. Spine 2000; 25:2566-2571.

127. Giordano J. Pain as disease and illness: Part Two - Structure and function of the ethics of pain medicine. Prac Pain Manage 2006; 6:65-68.

128. Bair MJ, Robinson RL, Katon W, Kroenke K. Depression and pain comorbidity: A literature review. Arch Intern Med 2003; 163:2433-2445.

129. Epker J, Block AR. Presurgical psychological screening in back pain patients: A review. Clin J Pain 2001; 17:200-205.

130. Dersh J, Gatchel RJ, Mayer T, Polatin P, Temple OR. Prevalence of psychiatric disorders in patients with chronic disabling occupational spinal disorders. Spine 2006; 31:1156-1162.

131. Manchikanti L, Pampati V, Fellows B, Beyer CD, Damron KS, Barnhill RC, Burks T. Characteristics of chronic low back pain in patients in an interventional pain management setting: A prospective evaluation. Pain Physician 2001; 4:131-142.

132. Manchikanti L, Pampati V, Beyer CD, Damron KS. Do number of pain conditions influence emotional status? Pain Physician 2002; 5:200-205.

133. McWilliams LA, Goodwin RD, Cox BJ. Depression and anxiety associated with three pain conditions: Results from a nationally representative sample. Pain 2004; 111:77-83. 
134. Fleming DA. Relieving pain: What are today's ethical and legal risks? Mo Med 2002; 99:560-565.

135. Fishman SM, Papazian JS, Gonzalez S, Riches PS, Gilson A. Regulating opioid prescribing through prescription monitoring programs: Balancing drug diversion and treatment of pain. Pain Med 2004; 5:309-324.

136. Cowan DT, Wilson-Barnett J, Griffiths P, Allan LG. A survey of chronic noncancer pain patients prescribed opioid analgesics. Pain Med 2003; 4:340-351.

137. Drug Enforcement Administration. Practitioner's Manual: An informational outline of the Controlled Substances Act of 1970. U.S. Department of Justice, Office of Diversion Control, Washington, DC, 2006.

138. Model Policy for the Use of Controlled Substances for the Treatment of Pain. The Federation of State Medical Boards of the United States. Inc., May 2004.

139. Lucas CE, Vlahos AL, Ledgerwood AM. Kindness kills: The negative impact of pain and the fifth vital sign. I Am Coll Surg 2007; 205:101-107.

140. Vila H, Smith RA, Augustyniak MJ, Nagi PA, Soto RG, Ross TW, Cantor AB, Strickland JM, Miguel RV. The efficacy and safety of pain management before and after implementation of hospitalwide pain management standards: Is patient safety compromised by treatment based solely on numerical pain ratings? Anesth Analg 2005; 101:47480.

141. Frasco PE, Sprung J, Trentman TL. The impact of the Joint Commission for Accreditation of Healthcare Organizations pain initiative on perioperative opiate consumption and recovery room length of stay. Anesth Analg 2005;100:162168.

142. Mularski RA, White-Chu F, Overbay D, Miller L, Asch SM, Ganzini L. Measuring pain as the 5 th vital sign does not improve quality of pain management. I Gen Intern Med 2006; 21:607-612.

143. Lieban A, Gatchel RJ, Polatin PB, Stowell AW. Cost-utility analysis of chronic spinal pain treatment outcomes: Converting SF-36 data into quality-adjusted life years. Clin J Pain 2006; 22:700711.

144. Kehlet H, Dahl JB. Anaesthesia, surgery, and challenges in postoperative recov ery. Lancet 2003; 362:1921-1928.

145. Brennan TJ, Kehlet H. Preventive analgesia to reduce wound hyperalgesia and persistent postsurgical pain. Not an easy path. Anesthesiol 2005; 103:681-683.
146. Manchikanti L, Damron KS, McManus CD, Barnhill RC. Patterns of illicit drug use and opioid abuse in patients with chronic pain at initial evaluation: A prospective, observational study. Pain Physician 2004; 7:431-437.

147. Fishbain DA, Rosomoff HL, Rosomoff RS. Drug abuse, dependence, and addiction in chronic pain patients. Clin J Pain 1992; 8:77-85.

148. Manchikanti L, Pampati V, Damron KS, Beyer CD, Barnhill RC, Fellows B. Prevalence of prescription drug abuse and dependency in patients with chronic pain in western Kentucky. J KY Med As SOC 2003; 101:511-517.

149. Manchikanti L, Damron KS, Pampati V, McManus CD. Prevalence of illicit drug use among individuals with chronic pain in the Commonwealth of Kentucky: An evaluation of patterns and trends. J Ky Med Assoc 2005; 103:5562.

150. Manchikanti L, Damron KS, Beyer CD, Pampati V. A comparative evaluation of illicit drug use in patients with or without controlled substance abuse in interventional pain management. Pain Physician 2003; 6:281-285.

151. Manchikanti L, Pampati V, Damron KS, Beyer CD, Barnhill RC. Prevalence of illicit drug use in patients without controlled substance abuse in interventional pain management. Pain Physician 2003; 6:173-178.

152. Manchikanti L, Manchukonda R, Pampati V, Damron KS, Brandon DE, Cash KA, McManus CD. Does random urine drug testing reduce illicit drug use in chronic pain patients receiving opioids? Pain Physician 2006; 9:123-129.

153. Vaglienti RM, Huber SJ, Noel KR, Johnstone RE. Misuse of prescribed controlled substances defined by urinalysis. WV Med J 2003; 99:67-70.

154. Katz NP, Sherburne S, Beach M, Rose RJ, Vielguth J, Bradley J, Fanciullo GJ. Behavioral monitoring and urine toxicology testing in patients receiving long-term opioid therapy. Anesth Analg 2003; 97:1097-1102.

155. Passik SD, Kirsh KL, McDonald MV, Ahn S, Russak SM, Martin L, Rosenfeld B, Breitbart WS, Portenoy RK. A pilot survey of aberrant drug-taking attitudes and behaviors in samples of cancer and AIDS patients. J Pain Symptom Manage 2000; 19:274-286.

156. Michna E, Jamison RN, Pham LD, Ross EL, Nedeljkovic SS, Narang S, Palombi $D$, Wasan AD. Urine toxicology screening among chronic pain patients on opioid therapy: Frequency and predictability of abnormal findings. Clin J Pain 2007; 23:173-179.

157. Manchikanti L, Damron KS, Pampati V, McManus CD, Weaver SE. Prospective evaluation of patients with increasing opiate needs: Prescription opiate abuse and illicit drug use. Pain Physician 2004; 7:339-344.

158. Manchikanti L, Cash KA, Damron KS, Manchukonda R, Pampati V, McManus CD. Controlled substance abuse and illicit drug use in chronic pain patients: An evaluation of multiple variables. Pain Physician 2006; 9:215-226.

159. Manchikanti L, Atluri S, Trescot A, Giordano J. Monitoring opioid adherence in chronic pain patients: Tools, techniques and utility. Pain Physician 2008; 11:S155-S180.

160. Ives TJ, Chelminski PR, Hammett-Stabler CA, Malone RM, Perhac JS, Potisek NM, Shilliday BB, DeWalt DA, Pignone MP. Predictors of opioid misuse in patients with chronic pain: A prospective cohort study. BMC Health Serv Res 2006; 6:46.

161. Manchikanti L, Manchukonda R, Pampati V, Damron KS. Evaluation of abuse of prescription and illicit drugs in chronic pain patients receiving short-acting (hydrocodone) or long-acting (methadone) opioids. Pain Physician 2005; 8:257-261.

162. Manchikanti L, Pampati V, Damron KS, McManus CD. Evaluation of variables in illicit drug use: Does a controlled substance abuse screening tool identify illicit drug use? Pain Physician 2004; 7:71-75.

163. Manchikanti L, Manchukonda R, Damron KS, Brandon D, McManus CD, Cash $\mathrm{KA}$. Does adherence monitoring reduce controlled substance abuse in chronic pain patients? Pain Physician 2006; 9:57-60.

164. Substance Abuse and Mental Health Services Administration, Office of Applied Studies (April 6, 2007). The NSDUH Report: Patterns and Trends in Nonmedical Prescription Pain Reliever Use: 2002 to 2005. Rockville, MD. http://oas.samhsa.gov/2k7/pain/ pain.htm

165. Office of National Drug Control Policy Executive Office of the President. Teens and prescription drugs. An analysis of recent trends on the emerging drug threat. February 2007. www.theantidrug.com/pdfs/TEENS_AND_PRESCRIPTION_DRUGS.pdf

166. Monitoring the Future (MTF), National 
Institute on Drug Abuse (NIDA). 2006. www.monitoringthefuture.org/pubs/ monographs/overview2006.pdf

167. Partnership for a Drug-Free America, The Partnership Attitude Tracking Study (PATS): Teens in grades 7 through 12, 2005. May 16, 2006. www. drugfree.org/Files/Full_Teen_Report

168. Boyd CJ, McCabe SE, Cranford JA, Young A. Adolescents' motivations to abuse prescription medications. Pediatrics 2006; 118:2472-2480.

169. Friedman RA. The changing face of teenage drug abuse - the trend toward prescription drugs. N Engl J Med 2006; 354:1448-1450.

170. Ballantyne JC. Opioids for chronic pain: Taking stock. Pain 2006; 125:3-4.

171. www.deadiversion.usdoj.gov/arcos/ retail_drug_summary/index.htmo

172. Testimony of Nora D. Volkow, M.D., Director, National Institute on Drug Abuse, National Institutes of Health, U.S. Department of Health and Human Services, before the Subcommittee on Criminal Justice, Drug Policy, and Human Resources Committee, July 26, 2006.

173. Kraman P. Drug abuse in America - prescription drug diversion. The Council of State Governments. April 2004. www. csg.org

174. McCaskill C. Oversight Controls in the State's Medicaid Prescription Drug Program, 18 April 2002, Performance Audit Report No. 2002-29, 4.

175. National Committee Pharmacists Association, NCPA Position Statements, Medicare Reform: JCPP Statement, August 10, 1999. www.ncpanet.org/ about/ncpa_position_statements/ m.shtml

176. Methadone Mortality Working Group Drug Enforcement Administration, Office of Diversion Control, April 2007.

177. U.S. Department of Health and Human Services. Substance Abuse and Mental Health Services Administration (SAMH SA). Background Information for Methadone Mortality - A Reassessment. Sponsored by the Center for Substance Abuse Treatment, Substance Abuse, and Mental Health Services Administration. Washington, DC, July 20, 2007.

178. Califano JA. High Society: How Substance Abuse Ravages American and What to Do About It. Perseus Publishing, New York, 2007.

179. Kuehn BM. Opioid prescriptions soar: Increase in legitimate use as well as abuse. JAMA 2007; 297:249-251.
180. Bollinger LC, Bush C, Califano JA, Chenault KI, Curtis JL, Dimon J, Dolan PR, Ganzi VF, Fisher M, Kelmenson LA, Keough DR, Kessler DA, Malloy EA, Pacheco MT, Plumeri II JJ, Redstone SE, Rosenwald Jr EJ, Schulhof MP, Sullivan LW, Sweeney JJ, Wiener MA. The National Center on Addiction and Substance Abuse at Columbia University (CASA). Under the Counter. The Diversion and Abuse of Controlled Prescription Drugs in the U.S. July 2005.

181. United Nations Office on Drugs and Crime. 2007 World Drug Report.

182. Caudill-Slosberg MA, Schwartz LM, Woloshin S. Office visits and analgesic prescriptions for musculoskeletal pain in U.S.: 1980 vs. 2000. Pain 2004; 109:514-519.

183. Vogt MT, Kwoh CK, Cope DK, Osial TA, Culyba M, Starz TW. Analgesic usage for low back pain: Impact on health care costs and service use. Spine 2005; 30:1075-1081.

184. Mahmud MA, Webster BS, Courtney TK, Matz S, Tacci JA, Christiani DC. Clinical management and the duration of disability for work-related low back pain. J Occup Environ Med 2000; 42:1178. 1187.

185. Webster BS, Verma SK, Gatchel RJ. Relationship between early opioid prescribing for acute occupational low back pain and disability duration, medical costs, subsequent surgery, and late opioid use. Spine 2007; 32:2127-2132.

186. Zacny J, Bigelow G, Compton P, Foley K, Iguchi M, Sannerud C. College on Problems of Drug Dependence task force on prescription opioid non-medical use and abuse (position statement). Drug Alcohol Depend 2003; 69:215-232.

187. Fillingim RB, Doleys DM, Edwards RR, Lowery D. Clinical characteristics of chronic back pain as a function of gender and oral opioid use. Spine 2003; 28:143-150.

188. Eriksen J, Sjogren P, Bruera E, Ekholm 0 , Rasmussen NK. Critical issues on opioids in chronic non-cancer pain. An epidemiological study. Pain 2006; 125:172-179.

189. Fleming MF, Balousek SL, Klessig CL, Mundt MP, Brown DD. Substance use disorders in a primary care sample receiving daily opioid therapy. J Pain 2007; 8:573-582.

190. Substance Abuse and Mental Health Services Administration (2007). Results from the 2006 National Survey on Drug Use and Health: National Findings. Office of Applied Studies, NSDUH Series
H-32, DHHS Publication No. SMA 074293. Rockville, MD. www.oas.samhsa.gov/nsduh/2k6nsduh/2k6results. pdf

191. Substance Abuse and Mental Health Services Administration. 2006. Results from the 2005 National Survey on Drug Use and Health: National Findings. Office of Applied Studies, NSDUH Series H-30, DHHS Publication No. SMA 064194. Rockville, MD. www.oas.samhsa.gov/nsduh/2k5nsduh/2k5Results. pdf

192. USA Today/HBO drug addiction poll, May 2006.

193. National Survey of American Attitudes on Substance Abuse XII: Teens and Parents. Center on Addiction and Substance Abuse (CASA) 2007.

194. Bhamb B, Brown D, Hariharan J, Anderson J, Balousek S, Fleming M. Survey of select practice behaviors by primary care physicians on the use of opioids for chronic pain. Curr Med Res Opin 2006; 22:1859-1865.

195. Upshur CC, Luckmann RS, Savageau JA. Primary care provider concerns about management of chronic pain in community clinic populations. Gen Intern Med 2006; 21:652-655.

196. Hariharan J, Lamb GC, Neuner JM. Longterm opioid contract use for chronic pain management in primary care practice. A five year experience. J Gen Intern Med 2007; 22:485-490.

197. Bendson P, Hensing G, Ebeling C, Sche$\operatorname{din} \mathrm{A}$. What are the qualities of dilemmas experienced when prescribing opioids in general practice? Pain 1999; 82:89-96.

198. Donovan MI, Evers K, Jacobs P, Mandleblatt $\mathrm{S}$. When there is no benchmark: Designing a primary care-based chronic pain management program from the scientific basis up. J Pain Symptom Manage 1999; 18:38-48.

199. U.S. Department of Health and Human Services. Office of Applied Studies, Substance Abuse and Mental Health Services Administration (SAMHSA). Drug Abuse Warning Network. The DAWN Report. Opiate-related drug misuse deaths in six states: Issue 19, 2006. https://dawninfo.samhsa.gov/ default.asp

200. Office of Applied Studies, SAMHSA, DAWN, 2005 (2006 update).

201. Baca C, Grant K. Mortality from opioid analgesics must not be ignored. Pain 2007; 128:288.

202. Paulozzi LJ, Budnitz DS, Xi Y. Increas- 
ing deaths from opioid analgesics in the United States. Pharmacoepidemiol Drug Saf 2006; 15:618-627.

203. Paulozzi L. Unintentional poisoning deaths - United States, 1999 - 2004 Centers for Disease Control and Prevention. MMWR Morb Mortal Wkly Rep 2007; 56:93-96. www.cdc.gov/mmwr/ preview/mmwrhtml/mm5605a1.htm

204. Department of Health and Human Services. Substance Abuse and Mental Health Services Administration, Center for Substance Abuse Treatment, Division of Pharmacologic Therapies. Methadone-Associated Mortality: Report of a National Assessment. dpt. samhsa.gov/reports/index.htm.

205. Fingerhut LA. Increases in methadonerelated deaths: 1999 - 2004. Health EStats. Hyattsville, MD: National Center for Health Statistics; 2006. www. cdc.gov/nchs/products/pubs/pubd/ hestats/methadone1999-04/methadone1999-04.htm

206. Centers for Disease Control and Prevention Centers for Disease Control and Prevention (CDC). Unintentional and undetermined poisoning deaths - 11 states, $1990-2001$. MMWR Morb Mortal Wkly Rep 2004; 53:233-238.

207. Hughes AA, Bogdan GM, Dart RC. Active surveillance of abused and misused prescription opioids using poison center data: A pilot study and descriptive comparison. Clin Toxicol (Phila) 2007; 45:144-151.

208. Testimony of Leonard J. Paulozzi, Medical Epidemiologist, National Center for Injury Prevention and Control, Centers for Disease Control and Prevention on Trends in Unintentional Drug Poisoning Deaths. Before The House Energy and Commerce Oversight and Investigations United States House of Representatives. October 24, 2007.

209. Chugh SS, Socoteanu C, Reinier K, Waltz J, Jui J, Gunson K. A community-based evaluation of sudden death associated with therapeutic levels of methadone. Am / Med 2008; 121:6671.

210. U.S. Food and Drug Administration, Center for Drug Evaluation and Research. FDA Public Health Advisory. Methadone Use for Pain Control May Result in Death and Life-threatening Changes in Breathing and Heartbeat. November 27, 2006. www.fda.gov/ cder/drug/advisory/methadone.htm

211. Edlund MJ, Steffick D, Hudson T, Harris KM, Sullivan M. Risk factors for clinically recognized opioid abuse and depen- dence among veterans using opioids for chronic non-cancer pain. Pain 2007; 129:355-362.

212. Rosenblum A, Joseph H, Fong C, Kipnis S, Cleland C, Portenoy R. Prevalence and characteristics of chronic pain among chemically dependent patients in methadone maintenance and residential treatment facilities. JAMA 2003; 289:2370-2378.

213. Adams EH, Breiner S, Cicero TJ, Geller A, Inciardi JA, Schnoll SH, Senay EC, Woody GE. A comparison of the abuse liability of tramadol, NSAIDs, and hydrocodone in patients with chronic pain. I Pain Symptom Manage 2006; 31:465-476.

214. Davstad I, Stenbacka M, Leifman A, Beck O, Korkmaz S, Romelsjo A. Patterns of illicit drug use and retention in a methadone program: A longitudinal study. J Opioid Manag 2007; 3:27-34.

215. Havens JR, Oser CB, Leukefeld CG. Increasing prevalence of prescription opiate misuse over time among rural probationers. J Opioid Manage 2007; 3:107-112.

216. Wiedemer NL, Harden PS, Arndt IO, Gallagher RM. The opioid renewal clinic: A primary care, managed approach to opioid therapy in chronic pain patients at risk for substance abuse. Pain Med 2007; 8:573-584.

217. Mahowald ML, Singh JA, Majeski $P$. Opioid use by patients in an orthopedics spine clinic. Arthritis Rheum 2005; 52:312-321.

218. White AG, Birnbaum HG, Mareva MN, Daher M, Vallow S, Schein J, Katz N. Direct costs of opioid abuse in an insured population in the United States. J Manag Care Pharm 2005; 11:469-479.

219. Center on Addiction and Substance Abuse. Substance Abuse and Federal Entitlement Programs. Columbia University, New York, 1995.

220. Held G. Linkages between substance abuse prevention and other human services. Literature Review June 1998, Part A.

221. Katz NP, Adams EH, Chilcoat H, Colucci RD, Comer SD, Goliber P, Grudzinskas C, Jasinski D, Lande SD, Passik SD, Schnoll SH, Sellers E, Travers D, Weiss $R$. Challenges in the development of prescription opioid abuse-deterrent formulations. Clin J Pain 2007; 23:648660.

222. Katz NP, Adams EH, Benneyan JC, Bimbaum HG, Budman SH, Buzzeo RW, Carr DB, Cicero TJ, Gourlay D, Inciardi
JA. Foundations of opioid risk management. Clin J Pain 2007; 23:103-118.

223. Katz N, Buse DC, Budman SH, Wing Venuli S, Fernabdez KC, Benoit C, Bianchi R, Cooper D, Jasnski DR, Smith DE. Development and preliminary experience with an ease of extractability rating system for prescription opioids. Drug Dev Ind Pharm 2006; 32:727746.

224. Testimony of Joseph T. Rannazzisi, Deputy Assistant Administrator, Office of Diversion Control, Drug Enforcement Administration. Before The Subcommittee on Criminal Justice, Drug Policy and Human Resources, July 26, 2006.

225. Paul R. Illegal internet pharmacies pose growing threat. Drug Topics, Aug 20, 2007. www.drugtopics.com/drugtopics/Community+Pharmacy/Illegal-Internet-pharmacies-pose-growing-threat/ArticleStandard/Article/detail/450106

226. Dasgupta N, Kramer ED, Zalman MA, Carino S, Smith M, Haddox JD, Wright C. Association between non-medical and prescriptive usage of opioids. Drug Alcohol Depend 2006; 82:135-142.

227. Fishman SM. Pain and politics: DEA, Congress and the courts (editorial). Pain Med 2006; 7:87-88.

228. Jung B, Reidenberg MM. The risk of action by the DEA against physicians prescribing opioids for pain. Pain Med 2006; 7:353-357.

229. Joranson DE, Gilson AM, Dahl JL, Haddox JD. Pain management, controlled substances, and state medical board policy: A decade of change. I Pain Symptom Manage. 2002; 23:138-147.

230. Gilson AM, Joranson DE. Controlled substances and pain management: Changes in knowledge and attitudes of state medical regulators. I Pain Symptom Manage 2001; 21:227-237.

231. Trescot AM, Datta S, Lee M, Hansen H. Opioid pharmacology. Pain Physician 2008; 11; S1333-S154.

232. Helm S, Trescot AM, Colson J, Sehgal N, Silverman S. Opioid antagonists, partial agonists and agonists/antagonists: The role of office-based detoxification. Pain Physician 2008; 11:225-236.

233. Smith HS. Variations in opioid responsiveness. Pain Physician 2008; 11:237248.

234. Smith HS. Peripherally-acting opioids. Pain Physician 2008; 11:S121-S132.

235. Smith HS. Combination opioid analgesics. Pain Physician 2008; 11:201-214. 
236. Gilbert JW, Wheeler GR, Lingreen RA, Upadhyay SP. Compliance in chronic noncancer pain patients on long-acting opiates, short-acting opiates, or nonopiates. Am J Pain Manage 2007; 17:1117.

237. Lewis DF. 57 varieties: The human cytochromes P450. Pharmacogenomics 2004; 5:305-318.

238. Breimer DD. Genetic polymorphism in drug metabolism: Clinical implications and consequences in ADME studies. In Walker S, Lumley C, McAuslane N (eds). The Relevance of Ethnic Factors in the Clinical Evaluation of Medicine Kluwer Academic Publishers, Dordrecht/Boston, 1994, pp 13-26.

239. Shapiro LE, Shear NH. Drug interac tions: Proteins, pumps, and P-450s. $J$ Am Acad Dermatol 2002; 47:467-484.

240. Evans DA, Mahgoub A, Sloan TP, Idle JR, Smith RL. A family and population study of the genetic polymorphism of debrisoquine oxidation in a white British population. J Med Genet 1980; 17:102-105.

241. Mercadante S. Pathophysiology and treatment of opioid-related myoclonus in cancer patients. Pain 1998; 74:5-9.

242. Han PKJ, Arnold R, Bond G, Janson D, Abu-Elmagd K. Myoclonus secondary to withdrawal from transdermal fentanyl: Case report and literature review. J Pain Symptom Manage 2002; 23:6672.

243. Moore P, Dimsdale JE. Opioids, sleep, and cancer-related fatigue. Med Hypotheses 2002; 58:77-82.

244. Slatkin N, Rhiner M. Treatment of opioid-induced delirium with acetylcholinesterase inhibitors: A case report. J Pain Symptom Manage 2004; 27:268273.

245. Fishbain DA, Cutler B, Rosomoff HL, Rosomoff RS. Are opioid-dependent/tolerant patients impaired in driving-related skills? A structured evidence-based review. J Pain Symptom Manage 2003; 25: 559-77.

246. Ersek M, Cherrier MM, Overman SS, Irving GA. The cognitive effects of opioids. Pain Manag Nurs 2004; 5: 75-93.

247. Harvard-MIT division of Health Sciences and Technology, HST.151 Principles of Pharmacology (Opioid Pharmacology) Spring 2003.

248. Ahmedzai S. New approaches to pain control in patients with cancer. Eur J Cancer 1997; 33:S8-S14.

249. Mercadante S, Villari P, Ferrera P. Burst ketamine to reverse opioid tolerance in cancer pain (letter). J Pain Symptom Manage 2003; 25:302-304.

250. Swegle JM, Logemann C. Management of common opioid-induced adverse effects. Am Fam Physician 2006; 74:13471354.

251. Hyman SE, Malenka RC, Nestler EJ. Neural mechanisms of addiction: The role of reward-related learning and memory. Annu Rev Neurosci 2006; 29:565598.

252. Nestler EJ. Historical review: Molecular and cellular mechanisms of opiate and cocaine addiction. Trends Pharmacol Sci 2004; 25:210-218.

253. Musto D. The American Disease, 3rd Edition. Oxford University Press; New York, NY, 1999.

254. DuPont RL (chair). Non-Medical Use of Methylphenidate: Defining the Problem, Creating Solutions - Report of an Advisory Committee to the Institute for Behavior and Health. Institute for Behavior and Health, Bethesda, MD 2005.

255. Drug Enforcement Administration. Physician's Manual: An informational outline of the Controlled Substances Act of 1970. Washington, DC: U.S. Department of Justice, 1990.

256. Center for Substance Abuse Treatment. Medication-Assisted Treatment for Opioid Addiction in Opioid Treatment Programs. Treatment Improvement Protocol (TIP) Series 43 (2005). DHHS Publication No. (SMA) 05-4048. Substance Abuse and Mental Health Services Administration, Rockville, MD.

257. Vocci F, Acri J, Elkashef A. Medications development for addictive disorders: The state of the science. Am J Psychiatry 2005; 162:1432-1440.

258. Chamberlin KW, Cottle M, Neville R, Tan J. Oral Oxymorphone for pain management. Ann Pharmacother 2007; 41:1144-1152.

259. Allan L, Richarz U, Simpson K, Slappendel R. Transdermal fentanyl versus sustained release oral morphine in strong opioid naïve patients with chronic low back pain. Spine 2005; 30:2484-2490.

260. Caldwell JR, Rapoport RJ, Davis JC, Offenberg HL, Marker HW, Roth SH, Yuan W, Eliot L, Babul N, Lynch PM. Efficacy and safety of a once-daily morphine formulation in chronic, moderate-to-severe osteoarthritis pain: Results from a randomized, placebo controlled, double-blind trial and an open-label extension trial. J Pain Symptom Manage 2002; 23:278-291.
261. Harati Y, Gooch C, Swenson M, Edelman SV, Greene D, Raskin P, Donofrio P, Cornblath D, Olson WH, Kamin M. Maintenance of the long-term effectiveness of tramadol in treatment of the pain of diabetic neuropathy. J Diabetes Complications 2000; 14:65-70.

262. Fredheim OM, Kaasa S, Dale O, Klepstad P, Landrø NI, Borchgrevink PC. Opioid switching from oral slow release morphine to oral methadone may improve pain control in chronic non-malignant pain: A nine-month follow-up study. Palliat Med 2006; 20:35-41.

263. Mcllwain H, Ahdieh H. Safety, tolerability, and effectiveness of oxymorphone extended release for moderate to severe osteoarthritis pain: $A$ one-year study. Am J Ther 2005; 12:106-112.

264. Roth SH, Fleischmann RM, Burch FX, Dietz F, Bockow B, Rapoport RJ, Rutstein J, Lacouture PG. Around-the-clock, controlled-release oxycodone therapy for osteoarthritis-related pain: Placebocontrolled trial and long-term evaluation. Arch Intern Med 2000; 160:853860.

265. Zenz M, Strumpf M, Tryba M. Longterm oral opioid therapy in patients with chronic nonmalignant pain. J Pain Symptom Manage 1992; 7:69-77.

266. Milligan K, Lanteri-Minet M, Borchert K, Helmers H, Donald R, Kress H-G, Adriaensen $H$, Moulin D, Järvimäki V, Haasen L. Evaluation of long-term efficacy and safety of transdermal fentanyl in the treatment of chronic noncancer pain. J Pain 2001; 2:197-204.

267. Mystakidou K, Parpa E, Tsilika E, Mavromati A, Smyrniotis V, Georgaki S, Vlahos L. Long-term management of noncancer pain with transdermal therapeutic system-fentanyl. J Pain 2003; 4:298306.

268. Caldwell JR, Hale ME, Boyd RE, Hague JM, Iwan T, Shi M, Lacouture PG. Treatment of osteoarthritis pain with controlled-release oxycodone or fixed combination oxycodone plus acetaminophen added to nonsteroidal antiinflammatory drugs: A double blind, randomized, multicenter, placebo controlled trial. J Rheumatol 1999; 26:862869.

269. Hale ME, Fleischmann R, Salzman R, Wild J, Iwan T, Swanton RE, Kaiko RF, Lacouture PG. Efficacy and safety of controlled-release versus immediaterelease oxycodone: Randomized, double blind evaluation in patients with chronic back pain. Clin J Pain 1999; 15:179-183. 
270. Salzman RT, Roberts MS, Wild J, Fabian C, Reder RF, Goldenheim PD. Can a controlled release oral dose form of oxycodone be used as readily as an immediate-release form for the purpose of titrating to stable pain control? J Pain Symptom Manage 1999; 18:271-279.

271. Allan L, Hays $\mathrm{H}$, Jensen $\mathrm{NH}$, de Waroux BL, Bolt M, Donald R, Kalso E. Randomized crossover trial of transdermal fentanyl and sustained-release oral morphine for treating chronic non-cancer pain. BMJ 2001; 322:1154-1158.

272. Hale M, Speight K, Harsanyi Z, Iwan T, Slagle NS, Lacouture PG, Darke AC. Efficacy of 12 hourly controlled-release codeine compared with as required dosing of acetaminophen plus codeine in patients with chronic low back pain. Pain Res Manage 1997; 2:33-38.

273. Gostick N, Allen J, Cranfield R. A comparison of the efficacy and adverse effects of controlled-release dihydroco deine and immediate-release dihydrocodeine in the treatment of pain in osteoarthritis and chronic back pain. In Twycross RG (ed). Proceedings of The Edinburgh Symposium on Pain Control and Medical Education; 1989:137-143.

274. Jamison RN, Raymond SA, Slawsby EA, Nedeljkovic SS, Katz NP. Opioid therapy for chronic noncancer back pain. A randomized prospective study. Spine 1998; 23:2591-2600.

275. Lloyd RS, Costello F, Eves MJ, James IG, Miller AJ. The efficacy and tolerability of controlled-release dihydrocodeine tab lets and combination dextropropoxyphene/paracetamol tablets in patients with severe osteoarthritis of the hips. Curr Med Res Opin 1992; 13:37-48.

276. Arkinstall W, Sandler A, Goughnour B, Babul N, Harsanyi Z, Darke AC. Efficacy of controlled-release codeine in chronic nonmalignant pain: A randomized, placebo controlled clinical trial. Pain 1995; 62:169-178.

277. Harke H, Gretenkort P, Ladleif HU, Rahman $\mathrm{S}$, Harke $\mathrm{O}$. The response of neuropathic pain and pain in complex regional pain syndrome I to carbamazepine and sustained-release morphine in patients pretreated with spinal cord stimulation: A double-blinded randomized study. Anesth Analg 2001; 92:488495.

278. Huse E, Larbig W, Flor H, Birbaumer N. The effect of opioids on phantom limb pain and cortical reorganization. Pain 2001; 90:47-55.

279. Moulin DE, lezzi A, Amireh R, Sharpe WK, Boyd D, Merskey H. Randomized trial of oral morphine for chronic noncancer pain. Lancet 1996; 347:143-147.

280. Peloso PM, Bellamy N, Bensen W, Thomson GT, Harsanyi Z, Babul N, Darke AC. Double blind randomized placebo control trial of controlled release codeine in the treatment of osteoarthritis of the hip or knee. J Rheumatol 2000; 27:764771.

281. Watson CP, Babul N. Efficacy of oxycodone in neuropathic pain: $A$ randomized trial in postherpetic neuralgia. Neurology 1998; 50:1837-1841.

282. Gimbel JS, Richards P, Portenoy RK. Controlled-release oxycodone for pain in diabetic neuropathy. Neurology 2003; 60:927-934.

283. Maier C, Hildebrandt J, Klinger R, Henrich-Eberl C, Lindena G, MONTAS Study Group. Morphine responsiveness, efficacy and tolerability in patients with chronic non-tumor associated pain - results of a double-blind placebocontrolled trial (MONTAS). Pain 2002; 97:223-233.

284. Attal N, Guirimand F, Brasseur L, Gaude V, Chauvin M, Bouhassira D. Effects of IV morphine in central pain. A randomized placebo-controlled study. Neurology 2002; 58:554-563.

285. Abs R, Verhelst J, Maeyaert J, Van Buyten JP, Opsomer F, Adriaensen H, Verlooy J, Van Havenbergh T, Smet M, Van Acker K. Endocrine consequences of long-term intrathecal administration of opioids. J Clin Endocrinol Metab 2000; 85:2215-2222.

286. Kasson BG, George R. Endocrine influences on the actions of morphine. I. Alteration of target gland hormones. J Pharmacol Exp Ther 1983; 224:273281.

287. Large RG, Schug SA. Opioids for chronic pain of non-malignant origin - caring or crippling? Health Care Anal 1995; 3:5-11.

288. Dellemijn PLI, van Duijn $\mathrm{H}$, Vanneste JAL. Prolonged treatment with trans dermal fentanyl in neuropathic pain. J Pain Symptom Manage 1998; 16:220229.

289. Watson CP, Moulin D, Watt-Watson J, Gordon A, Eisenhoffer J. Controlled-release oxycodone relieves neuropathic pain: A randomized controlled trial in painful diabetic neuropathy. Pain 2003; 105:71-78.

290. Robbins L. Daily opioids (methadone) for refractory chronic daily headache. Headache Quart 1996; 7:39-42.

291. Robbins L. Long-acting opioids (methadone) for refractory chronic daily head- ache: Quality of life assessment. Headache Quart 1997; 8:234-236.

292. Mironer YE, Haasis JC III, Chapple IT, Somerville JJ, Barsanti JM. Successful use of methadone in neuropathic pain: A multicenter study by the National Forum of Independent Pain Clinicians. Pain Digest 1999; 9:191-193.

293. Quang-Cantagrel ND, Wallace MS, Magnuson SK. Opioid substitution to improve the effectiveness of chronic noncancer pain control: A chart review. Anesth Analg 2000; 90:933-937.

294. Moulin DE, Palma D, Watling C, Schulz $\mathrm{V}$. Methadone in the management of intractable neuropathic pain. Pain Res Manag 2003; 8:51B.

295. Katz N. Methodological issues in clinical trials of opioids for chronic pain. Neurology 2005; 65:S32-S49.

296. Maier C, Schaub C, Willweber-Strumpf A, Zenz M. Long-term efficacy of opioid medication in patients with chronic non-cancer-associated pain. Results of a survey 5 years after onset of medical treatment. Schmerz 2005; 19:410-417.

297. Tassain V, Attal N, Fletcher D, Brasseur L, Degieux P, Chauvin M, Bouhassira D. Long term effects of oral sustained release morphine on neuropsychological performance in patients with chronic non-cancer pain. Pain 2003; 104:389400.

298. Rauck RL, Bookbinder SA, Bunker TR, Alftine $C D$. A randomized, open-label, multicenter trial comparing once-aday Avinza (morphine sulfate extended-release capsules) versus twice-aday OxyContin (oxycodone hydrochloride controlled release tablets) for the treatment of chronic, moderate to severe low back pain: Improved physical functioning in the ACTION trial. J Opioid Manage 2007; 3:35-43.

299. Hermos JA, Young MM, Gagnon DR, Fiore LD. Characterizations of long-term oxycodone/acetaminophen prescriptions in veteran patients. Arch Intern Med 2004; 164:2361-2366.

300. Portenoy RK, Farrar JT, Backonja MM, Cleeland CS, Yang K, Friedman M, Coluci SV, Richards P. Long-term use of controlled-release oxycodone for noncancer pain: Results of a 3-year registry study. Clin J Pain 2007; 23:287-299.

301. Fredheim OMS, Borchgrevink PC, Klepstad P, Kaasa S, Dale O. Long-term methadone for chronic pain: A pilot study of pharmacokinetic aspects. Eur J Pain 2007; 11:599-604.

302. Beaulieu AD, Peloso P, Bensen W, Clark AJ, Watson CPN, Gardner-Nix J, Thomp- 
son G, Piraino PS, Eisenhhoffer J, Harsanyi Z, Darke AC. A randomized, double-blind, 8-week crossover study of once-daily controlled-release tramadol versus immediate-release tramadol taken as needed for chronic noncancer pain. Clin Ther 2007; 29:49-60.

303. Adams EH, Chwiecko P, Ace-Wagoner $Y$, Mangefrida B, Duerden ME, Perdikis GC, Kunkel FA, Ghalie R. A study of Avinza (morphine sulfate extended-release capsules) for chronic moderateto-severe noncancer pain conducted under real-world treatment conditions - the ACCPT study. Pain Pract 2006; 6:254-264.

304. Rauck R, Ma T, Kerwin R, Ahdieh H. Titration with oxymorphone extended release to achieve effective long-term pain relief and improved tolerability in opioid-naïve patients with moderate to severe pain. Pain Med 2007 (Published article online: 7-Dec-2007).

305. Cone J, Heit H, Caplan YH, Gourlay D. Evidence of morphine metabolism to hydromorphone in pain patients chronically treated with morphine. J Anal Toxicol 2006;30:1-5.

306. Wasan A, Michna E, Janfaza D, Teter C, Greenfield S, Jamison R. Interpreting urine drug tests: prevalence of morphine metabolism to hydromorphone in chronic pain patients treated with morphine. Reg Anesth Pain Med 2006;30:A7.

307. Boswell MV, Singh V, Staats PS, Hirsch JA. Accuracy of precision diagnostic blocks in the diagnosis of chronic spinal pain of facet or zygapophysial joint origin: A systematic review. Pain Physician 2003; 6:449-456.

308. Boswell MV, Colson JD, Spillane WF. Therapeutic facet joint interventions in chronic spinal pain: A systematic review of effectiveness and complications. Pain Physician 2005; 8:101-114.

309. Boswell MV, Colson JD, Sehgal N, Dunbar EE, Epter R. A systematic review of therapeutic facet joint interventions in chronic spinal pain. Pain Physician 2007; 10:229-254.

310. Sehgal N, Shah RV, McKenzie-Brown A, Everett CR. Diagnostic utility of facet (zygapophysial) joint injections in chronic spinal pain: A systematic review of evidence. Pain Physician 2005; 8:211-224.

311. Seghal N, Dunbar EE, Shah RV, Colson JD. Systematic review of diagnostic utility of facet (zygapophysial) joint injections in chronic spinal pain: An update. Pain Physician 2007; 10:213-228.
312. Shah RV, Everett CR, McKenzie-Brown AM, Sehgal N. Discography as a diag. nostic test for spinal pain: A systematic and narrative review. Pain Physician 2005; 8:187-209.

313. Abdi S, Datta S, Trescot AM, Schultz DM, Adlaka R, Atluri SL, Smith HS, Manchikanti L. Epidural steroids in the management of chronic spinal pain: A systematic review. Pain Physician 2007; 10:185-212.

314. Datta S, Everett CR, Trescot AM, Schultz DM, Adlaka R, Abdi S, Atluri SL, Smith HS, Shah RV. An updated systematic review of diagnostic utility of selective nerve root blocks. Pain Physician 2007; 10:113-128.

315. Trescot AM, Chopra P, Abdi S, Datta S, Schultz DM. Systematic review of effectiveness and complications of adhesiolysis in the management of chronic spinal pain: An update. Pain Physician 2007; 10: 129-146.

316. Buenaventura RM, Shah RV, Patel V, Benyamin R, Singh V. Systematic review of discography as a diagnostic test for spinal pain: An update. Pain Physician 2007; 10:147-164.

317. Hansen HC, McKenzie-Brown AM, Cohen SP, Swicegood JR, Colson JD, Manchikanti L. Sacroiliac joint interventions: A systematic review. Pain Physician 2007; 10:165-184.

318. Bogduk N, Lord S. Cervical zygapophysial joint pain. Neurosurg Q 1998; 8:107-117.

319. Barnsley L, Lord S, Wallis B, Bogduk N. False-positive rates of cervical zyg apophysial joint blocks. Clin J Pain 1993; 9:124-130.

320. Barnsley L, Lord S, Bogduk N. Comparative local anesthetic blocks in the diagnosis of cervical zygapophysial joints pain. Pain 1993; 55:99-106.

321. Lord SM, Barnsley L, Bogduk N. The utility of comparative local anesthetic blocks versus placebo-controlled blocks for the diagnosis of cervical zygapophysial joint pain. Clin J Pain 1995; 11:208-213.

322. Lord SM, Barnsley L, Wallis BJ, Bogduk N. Chronic cervical zygapophysial joint pain with whiplash: A placebo-controlled prevalence study. Spine 1996; 21:1737-1745.

323. Bogduk N. International spinal injection society guidelines for the performance of spinal injection procedures. Part 1. Zygapophysial joint blocks. Clin J Pain 1997; 13:285-302.

324. Bogduk N. Cervical medial branch blocks. In Practice Guidelines for Spinal Diagnostic and Treatment Procedures, 1st edition. International Spine Intervention Society, 2004, pp 112-137.

325. Manchikanti L, Manchikanti KN, Manchukonda R, Pampati V, Cash KA. Evaluation of therapeutic thoracic medial branch block effectiveness in chronic thoracic pain: A prospective outcome study with minimum 1-year follow up. Pain Physician 2006; 9:97-105.

326. Manchikanti L, Damron KS, Cash KA, Manchukonda R, Pampati V. Therapeutic medial branch blocks in managing chronic neck pain: A preliminary report of a randomized, double-blind, controlled trial: Clinical Trial NCTo033272. Pain Physician 2006; 9:333-346.

327. Manchikanti L, Pampati V, Fellows B, Bakhit CE. The diagnostic validity and therapeutic value of lumbar facet joint nerve blocks with or without adjuvant agents. Curr Rev Pain 2000; 4:337344 .

328. Manchikanti L, Rivera JJ, Pampati V, Damron KS, MCManus CD, Brandon $D E$, Wilson SR. One day lumbar epidural adhesiolysis and hypertonic saline neurolysis in treatment of chronic low back pain: A randomized, double-blind trial. Pain Physician 2004; 7:177-186

329. Manchikanti L, Saini B, Singh V. Spinal endoscopy and lysis of epidural adhesions in the management of chronic low back pain. Pain Physician 2001; 4:240-265.

330. Manchikanti L, Pampati V, Fellows B, Rivera JJ, Beyer CD, Damron KS. Role of one day epidural adhesiolysis in management of chronic low back pain: A randomized clinical trial. Pain Physician 2001; 4:153-166.

331. Gourlay DL, Heit HA, Almahrezi A. Universal precautions in pain medicine: $A$ rational approach to the treatment of chronic pain. Pain Med 2005; 6:107112.

332. Manchikanti L. Recent developments in evaluation and management services. Pain Physician 2000; 3:403-421.

333. Manchikanti L. Evaluation and management in interventional pain practice: Doing it right! Pain Physician 2000; 3:322-341.

334. Manchikanti L. Role of evaluation and management services in pain management. Pain Physician 1999; 2:10-32.

335. Manchikanti L. Documentation for evaluation and management services. In Manchikanti L (ed). Interventional Pain Management: Principles and Practice 
of Documentation, Billing, Coding, and Practice Management. ASIPP Publishing, Paducah KY 2004; pp 31-46.

336. Bolen JE. Documentation in an interventional pain management office. In Manchikanti L (ed). Principles of Documentation, Billing, Coding \& Practice Management for the Interventional Pain Professional, ASIPP Publishing, Paducah KY, 2004, pp 21-26.

337. Bolen JE. Documentation for hospital outpatient department. In Manchikanti $\mathrm{L}$ (ed). Principles of Documentation, Billing, Coding \& Practice Management for the Interventional Pain Pro fessional, ASIPP Publishing, Paducah KY, 2004, pp 27-30.

338. Andersson GB, Mekhail NA, Block JE. Treatment of intractable discogenic low back pain. A systematic review of spinal fusion and intradiscal electrothermal therapy (IDET). Pain Physician 2006; 9:237-248.

339. Everett CR, Shah RV, Sehgal N, McKenzie-Brown AM. A systematic review of diagnostic utility of selective nerve root blocks. Pain Physician 2005; 8:225233.

340. Abdi S, Datta S, Lucas LF. Role of epidural steroids in the management of chronic spinal pain: A systematic review of effectiveness and complications. Pain Physician 2005; 8:127-143.

341. McKenzie-Brown AM, Shah RV, Sehgal $N$, Everett CR. A systematic review of sacroiliac joint interventions. Pain Physician 2005; 8:115-125

342. Chopra P, Smith HS, Deer TR, Bowman RC. Role of Adhesiolysis in the management of chronic spinal pain: A systematic review of effectiveness and complications. Pain Physician 2005; 8:87100.

343. Boswell MV, Hansen HC, Trescot AM, Hirsch JA. Epidural steroids in the management of chronic spinal pain and radiculopathy. Pain Physician 2003; 6:319-334.

344. Manchikanti L, Singh V, Vilims BD, Hansen HC, Schultz DM, Kloth DS. Medial branch neurotomy in management of chronic spinal pain: Systematic review of the evidence. Pain Physician 2002; 5:405-418.

345. Turner JA, Sears JM, Loeser JD. Programmable intrathecal opioid delivery systems for chronic non-malignant pain: A systematic review of effectiveness and complications. Clin J Pain
2007; 23:180-195

346. Manchikanti L, Singh V, Pampati V, Damron KS, Barnhill RC, Beyer CD, Cash $\mathrm{KA}$. Evaluation of the relative contributions of various structures in chronic low back pain. Pain Physician 2001; 4:308-316.

347. Manchikanti L, Pampati V, Baha A, Fellows B, Damron KS, Barnhill RC. Contribution of facet joints to chronic low back pain in postlumbar laminectomy syndrome: A controlled comparative prevalence evaluation. Pain Physician 2001; 4:175-180.

348. Yang KH, King Al. Mechanism of facet load transmission as a hypothesis for low-back pain. Spine 1984; 9:557-565.

349. Mayer TG, Gatchel RJ, Keeley J, McGeary D, Dersh J, Anagnostis C. A randomized clinical trial of treatment for lumbar segmental rigidity. Spine 2004; 29:2199-2205.

350. Mayer T, Robinson R, Pegues P, Kohles $S$, Gatchel RJ. Lumbar segmental rigidity: Can its identification with facet injections and stretching exercises be useful? Arch Phys Med Rehabil 2000; 81:1143-1150. 